\title{
Performance Assessment Monitoring Plan for the Hanford Site Low-Level Burial Grounds
}

Prepared for the U.S. Department of Energy Assistant Secretary for Environmental Management

Project Hanford Management Contractor for the

U.S. Department of Energy under Contract DE-AC06-96RL13200

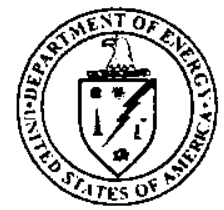

\section{United States Department of Energy} P.O. Box 550

Richland, Washington 99352 


\title{
INFORMATION CLEARANCE FORM
}

\begin{tabular}{|ll|}
\hline \multicolumn{2}{|c|}{ A. Information Category } \\
$\square$ Abstract & $\square$ Journal Article \\
$\square$ Summary & $\square$ Internet \\
$\square$ Visual Aid & $\square$ Software \\
$\square$ Full Paper & $\square$ Report \\
$\square$ Other &
\end{tabular}

\author{
B. Document Number DOE/RL-2000-72, REV. 0 \\ C. Title \\ PERFORMANCE ASSESSMENT MONITORING PLAN FOR THE HANEORD SITE \\ LOW-LEVEL BURIAL GROUNDS
}

D. Internet Address

E. Required Information

1. Is document potentially Classified? $\square$ No $\square$ Yes (MANDATORY)

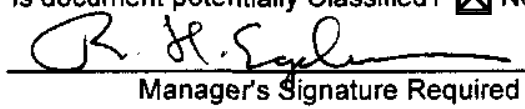

If Yes

Manager's Signature Required

ADC Signature Required

2. Internal Review Required?
If Yes, Document Signatures Below $\quad \square$ No $\bigotimes$ Yes

$\bigotimes_{\text {No }} \square$ Yes Classified

Counsel

Program

3. References in the information are Applied Technology $\bigotimes$ No $\square$ Yes

Export Controlled Information

$\bigotimes_{\text {No }} \square$ Yes

4. Does Information Contain the Following: (MANDATORY)

a. New or Novel (Patentable) Subject Matter? $\quad$ No $\square$ Yes

If "Yes", Disclosure No.:

b. Information Received in Confidence, Such as Proprietary and/or Inventions?

$\bigotimes$ No $\square$ Yes . If "Yes", Affix Appropriate Legends/Notices.

c. Copyrights? $\bigotimes$ No $\square$ Yes If "Yes", Attach Permission.

d. Trademarks? $\square$ No $\square$ Yes If "Yes", Identify in Document.

5. Is Information requiring submission to OSTI? $\quad \square$ No $\square$ Yes

If Yes $U C-$ and $B \& R-$

6. Release Level? $\triangle$ Public $\square$ Limited

F. Complete for a Journal Article

1. Title of Journal

G. Complete for a Presentation

1. Title for Conference or Meeting

2. Group Sponsoring

\begin{tabular}{l} 
3. Date of Conference \\
5. Will Information be Published in Proceedfigs? \\
\hline H. Author/Requestor \\
J. C. SONNICHSEN, \\
\hline I. Revint and Sign)
\end{tabular}

4. City/State

6. Will Material be Handed Out? $\square$ No $\square$ Yes

H. Author/Requestor

I. Reviewers

General Counsel 邓

Office of External Affairs

DOE-RL

L. F. WILLIS

(Print and Sign)

Other

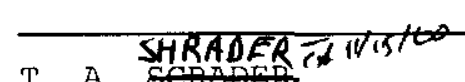

Signatrite

T. A. EERADER

$5+\infty$

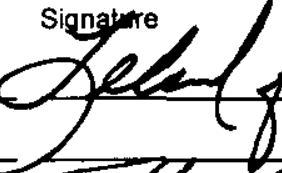

$8 / 59-19$

.




\section{Performance Assessment Monitoring Plan for the Hanford Site Low-Level Burial Grounds}

Date Published

November 2000

Prepared for the U.S. Department of Energy

Assistant Secretary for Environmental Management

Project Hanford Management Contractor for the

U.S. Department of Energy under Contract DE-AC06-96RL13200

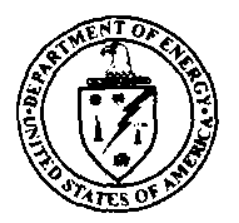

\section{United States} Department of Energy

P.O. Box 550

Richland, Washington 99352

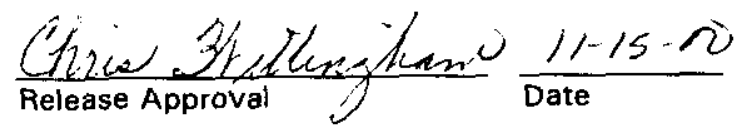


LEGAL DISCLAIMER

This report was prepared as an account of work sponsored by an agency of the United States Government. Neither the United States Government nor any agency thereof, nor any of their employees, nor any of their contractors, subcontractors or their employees, makes any warranty, express or implied, or assumes any legal liability or responsibility for the accuracy, completeness, or any third party's use or the results of such use of any information, apparatus, product, or process disclosed, or represents that its use would not infringe privately owned rights. Reference herein to any specific commercial product, process, or service by trade name, trademark, manufacturer, or otherwise, does not necessarily constitute or imply its endorsement, recommendation, or favoring by the United States Government or any agency thereof or its contractors or subcontractors. The views and opinions of authors expressed herein do not necessarily state or reflect those of the United States Government or any agency thereof.

This report has been reproduced from the best available copy. 


\section{EXECUTIVE SUMMARY}

As directed by the U.S. Department of Energy, Richland Operations Office, Fluor Hanford, Inc. will implement the requirements of U.S. Department of Energy Order 435.1, Radioactive Waste Management, as these requirements relate to the continued operation of the low-level waste disposal facilities on the Hanford Site. U.S. Department of Energy Order 435.1 requires a disposal authorization statement for continued operation of existing low-level waste disposal facilities. Conditional authorization to transfer, receive, possess, and dispose of low-level radioactive waste at the 200 East Area and the 200 West Area Low-Level Burial Grounds on the Hanford Site was issued on October 25, 1999. One condition was that a performance monitoring plan for these disposal facilities be written and approved by the U.S. Department of Energy, Richland Operations Office. In response to this requirement, Fluor Hanford, Inc. contracted with the Pacific Northwest National Laboratory to prepare this plan. The required plan consists of the following three components:

- Air

- Groundwater

- Subsidence.

The approach to obtain this information was to use as much data from the existing Hanford Site environmental monitoring program as possible. Accordingly, the existing program was considered adequate for the air and subsidence components. The existing groundwater component, however, required addition of long-lived mobile radionuclides identified in the Low-Level Burial Grounds performance assessments and composite analysis. Of the six radionuclides previously identified (carbon-14, selenium-79, chlorine-36, uranium-isotopes, iodine-129, and technetium-99) only the last three will be added. (A relative hazard index approach was used to limit the analytes to only those that accounted for $>99 \%$ of the hypothetical dose to an exposed individual.)

The primary objective of performance assessment monitoring is to detect increasing trends that can be attributed to the Low-Level Burial Grounds and to ensure the performance objectives are being met (e.g., $4 \mathrm{mrem} / \mathrm{yr}$ for groundwater pathway). Statistical tests that could be used to evaluate such trends are described. However, in some cases, existing contamination from adjacent sources might preclude evaluation of the groundwater pathway until the existing contaminant plumes have dissipated sometime in the future.

A summary table of sample media, approach, analytical methods, sample frequency, action levels, and reporting is provided. A diagram showing the responsible organizations, how the acquired information will be compiled and evaluated, and how the plan will be implemented is provided. 
3

4

5

6

This page intentionally left blank. 


\section{CONTENTS}

EXECUTIVE SUMMARY iii

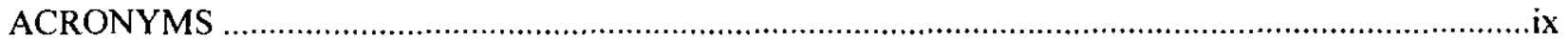

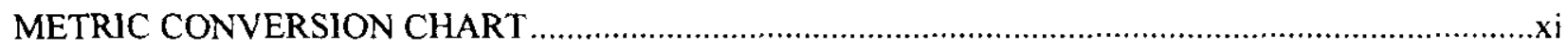

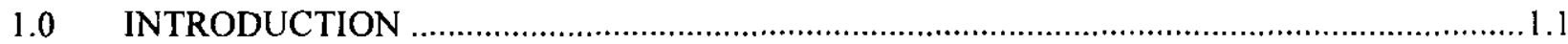

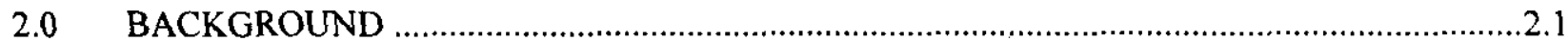

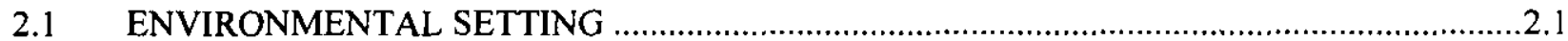

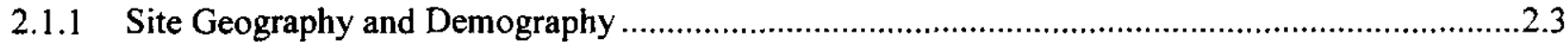

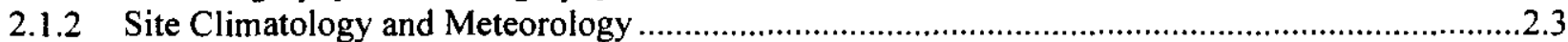

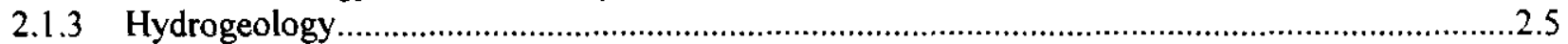

2.2 APPROACH LINKING PERFORMANCE ASSESSMENT AND OPERATIONAL

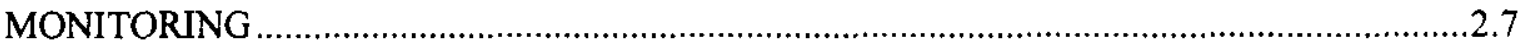

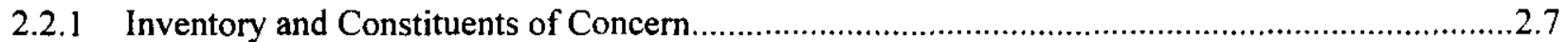

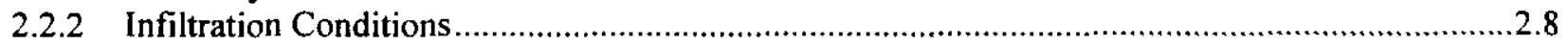

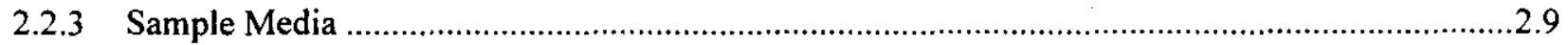

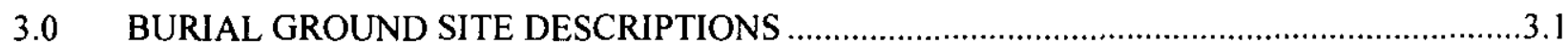

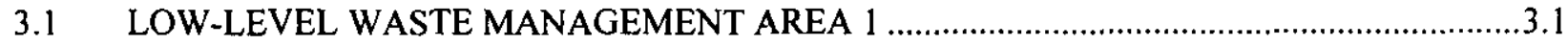

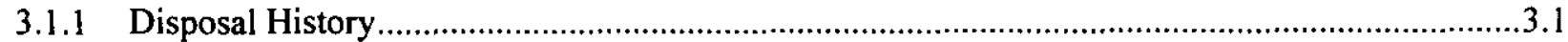

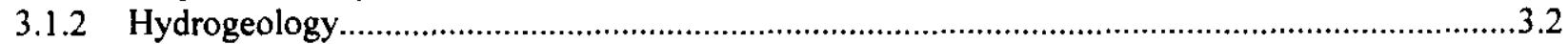

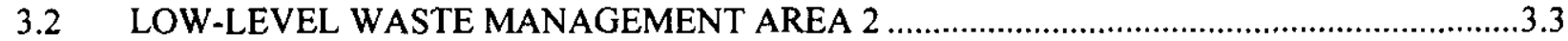

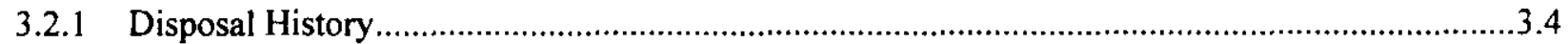

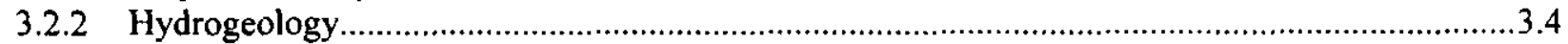

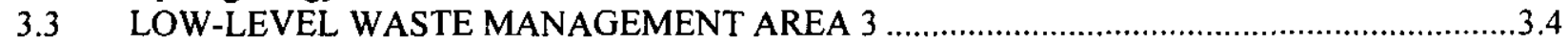

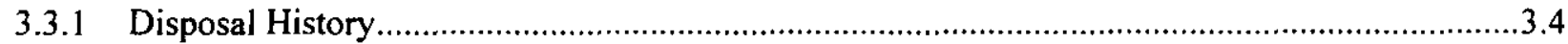

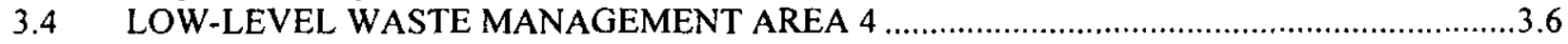

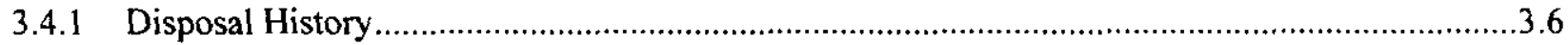

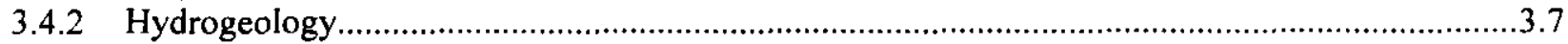

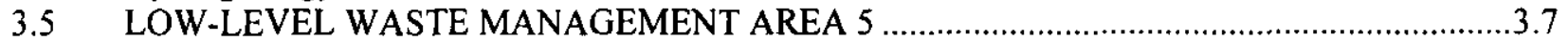

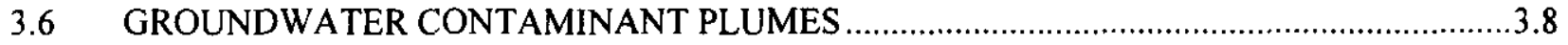

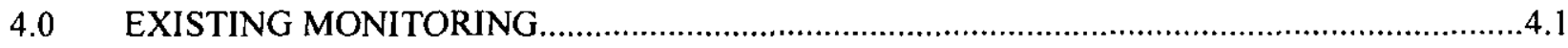

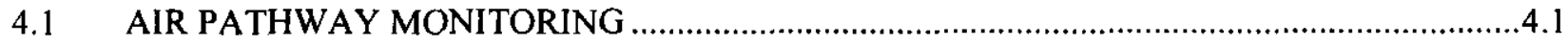

4.1.1 Near-Facility Environmental Monitoring Program........................................................... 4.1

4.1.2 Sitewide Surface Environmental Surveillance Program ............................................................ 4.2

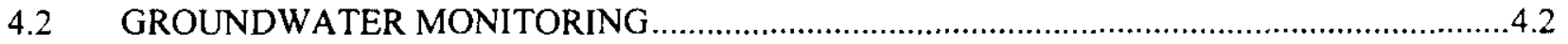

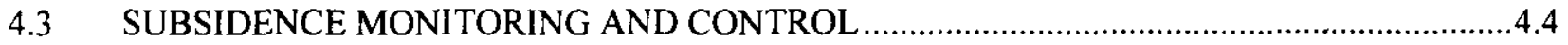

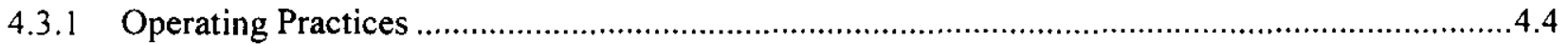

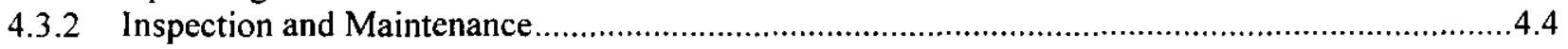

$5.0 \quad$ MONITORING BASELINE AND STATISTICAL ANALYSIS ........................................ 5.1

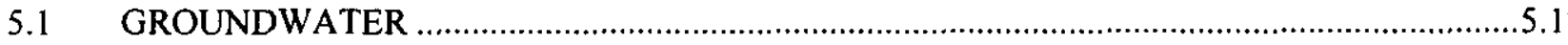

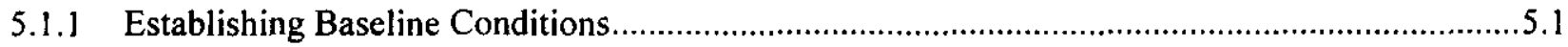

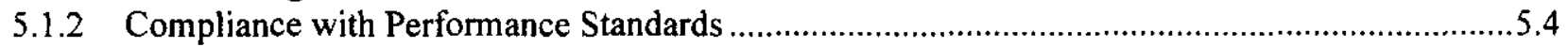

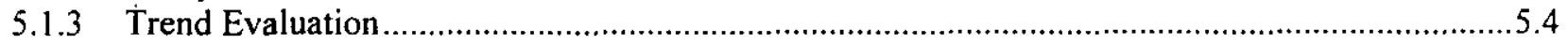




\section{CONTENTS (cont)}

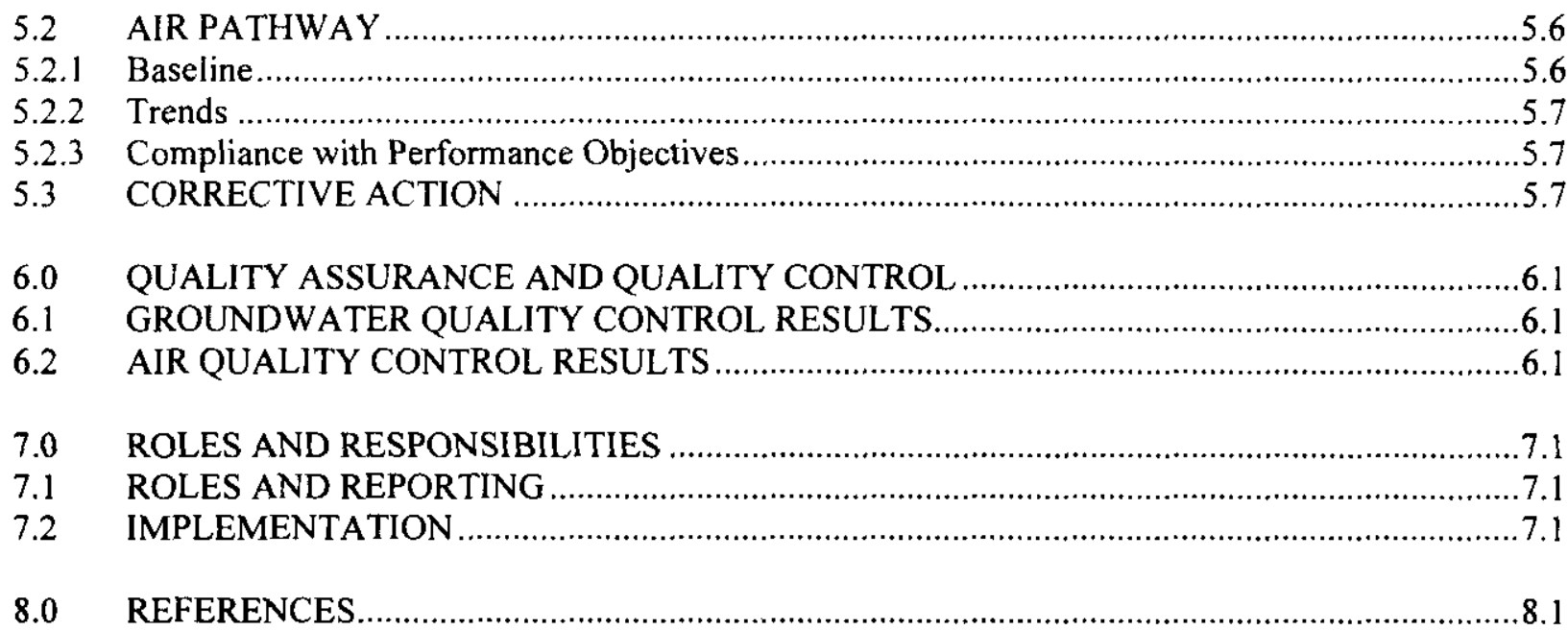

\section{APPENDICES}

A Relative Hazard Index Values and List of Constituents for the 200 Areas Low-Level Burial Grounds

B Locations of Individual Trenches and Types of Wastes Contained in Each Burial Ground.

C Selected Groundwater Contaminant Plume Maps in the 200 East and 200 West Areas...........APP C.1

D Existing Sampling and Analysis Schedules for the RCRA Groundwater Monitoring Program for the 200 Areas Low-Level Burial Grounds APP D.1

Figure 2.1. Location of 200 East and 200 West Area Low-Level Waste Management Areas on the Hanford Site.

Figure 2.2. Hanford Meteorological Monitoring Network Wind Roses at 10-Meter Level, 1982 Through 1999 (from Hoitink et al. 2000).....

Figure 2.3. Conceptual Model of Contaminant Migration under Operational and Post-Closure Conditions.

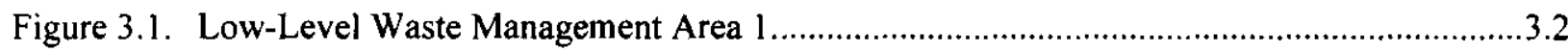

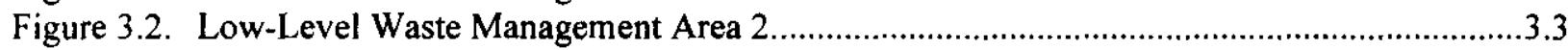

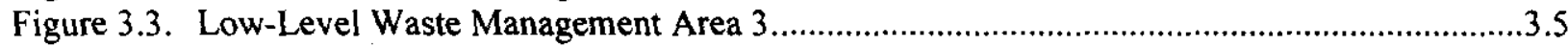

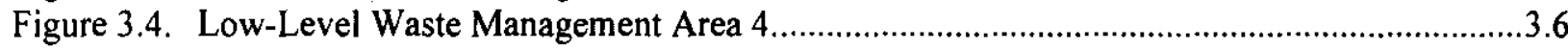

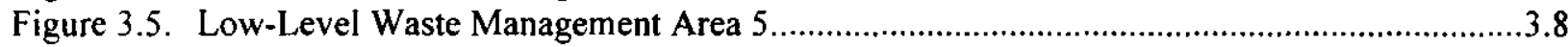




\section{FIGURES (cont)}

Figure 4.1. Air Surveillance Sampling Locations, 1999 (PNNL-13230).

Figure 5.1. An Overview of the General Process Flow for Establishing Baseline Conditions and Evaluation for Compliance

Figure 7.1. Data Collection and Reporting Road Map. . .7 .3$

\section{TABLES}

Table 1.1. Performance Objectives for 200 East and West Area Low-Level Burial Grounds. 1.2

Table 2.1. Low-Level Waste Management Areas.

Table 2.2. List of Radiological Constituents and $4 \mathrm{mrem} / \mathrm{yr}$ Equivalent Concentrations for the 200 East and 200 West Areas Burial Grounds.

Table 7.1. Summary Table of Sample Media, Method, Constituents, Analytical Method, Sample Location, Sample Frequency, Action Level, and Reporting for the Low-Level Burial Grounds Performance Assessment Monitoring. 
This page intentionally left blank. 
2

3

4

5

6

7

8

9

10

11

12

13

\section{ACRONYMS}

AL

B-Pond

CA

CERCLA

CUSUM

$\mathrm{CCL}$

DCG

DOE

DOE-RL

DWS

Ecology

EPA

GW

LLBG

LLWMA

LOQ

$\mathrm{MCL}$

PA

PNNL

PUREX

QA

QC

RCRA

SCL

TI

TRU

TSD unit

U-Pond

WAC

action level

216 B-Pond System

composite analysis

Comprehensive Environmental Response, Compensation and Liability Act of 1981

cumulative sum

CUSUM control limit

derived concentration guide

U.S. Department of Energy

U.S. Department of Energy, Richland Operations Office

drinking water standards

Washington State Department of Ecology

U.S. Environmental Protection Agency

groundwater

Low-Level Burial Grounds

low-level waste management area

limit of quantitation

maximum contaminant level

performance assessment

Pacific Northwest National Laboratory

Plutonium-Uranium Extraction Plant

quality assurance

quality control

Resource Conservation and Recovery Act of 1976

Shewhart control limit

tolerance interval

transuranic

treatment, storage, and/or disposal unit

216-U-10 Pond

Washington Administrative Code 
2

3

$4 \sim$

$5{ }^{\circ} \mathrm{C}$

$6 \mathrm{yr}$

$7>$

$8 \leq$

$9 \mathrm{~cm} / \mathrm{y}$

$10 \mathrm{mrem} / \mathrm{yr}$

$11 \mathrm{pCi} / \mathrm{m}^{2} / \mathrm{s}$

$12 \mathrm{pCi} / \mathrm{L}$

$13 \mu \mathrm{g} / \mathrm{L}$

\section{ACRONYMS (cont)}

approximately

degrees Celsius

year

greater than

less than or equal to

centimeter per year

millirem per year

picocuries per square meter per second

picocuries per liter

micrograms per liter 


\section{METRIC CONVERSION CHART}

Into metric units
Out of metric units

\begin{tabular}{|c|c|c|c|c|c|}
\hline If you know & Multiply by & To get & If you know & Multiply by & To get \\
\hline \multicolumn{3}{|c|}{ Length } & \multicolumn{3}{|c|}{ Length } \\
\hline inches & 25.40 & millimeters & millimeters & 0.0393 & inches \\
\hline inches & 2.54 & centimeters & centimeters & 0.393 & inches \\
\hline feet & 0.3048 & meters & meters & 3.2808 & feet \\
\hline yards & 0.914 & meters & meters & 1.09 & yards \\
\hline miles & 1.609 & kilometers & kilometers & 0.62 & miles \\
\hline \multicolumn{3}{|c|}{ Area } & \multicolumn{3}{|c|}{ Area } \\
\hline square inches & 6.4516 & $\begin{array}{l}\text { square } \\
\text { centimeters }\end{array}$ & $\begin{array}{l}\text { square } \\
\text { centimeters }\end{array}$ & 0.155 & $\begin{array}{l}\text { square } \\
\text { inches }\end{array}$ \\
\hline square feet & 0.092 & square meters & square meters & 10.7639 & square feet \\
\hline square yards & 0.836 & square meters & square meters & 1.20 & square yards \\
\hline square miles & 2.59 & $\begin{array}{l}\text { square } \\
\text { kilometers }\end{array}$ & $\begin{array}{l}\text { square } \\
\text { kilometers }\end{array}$ & 0.39 & square miles \\
\hline acres & 0.404 & hectares & hectares & 2.471 & acres \\
\hline \multicolumn{3}{|c|}{ Mass (weight) } & \multicolumn{3}{|c|}{ Mass (weight) } \\
\hline ounces & 28.35 & grams & grams & 0.0352 & ounces \\
\hline pounds & 0.453 & kilograms & kilograms & 2.2046 & pounds \\
\hline short ton & 0.907 & metric ton & metric ton & 1.10 & short ton \\
\hline \multicolumn{3}{|c|}{ Volume } & \multicolumn{3}{|c|}{ Volume } \\
\hline fluid ounces & 29.57 & milliliters & milliliters & 0.03 & fluid ounces \\
\hline quarts & 0.95 & liters & liters & 1.057 & quarts \\
\hline gallons & 3.79 & liters & liters & 0.26 & gallons \\
\hline cubic feet & 0.03 & cubic meters & cubic meters & 35.3147 & cubic feet \\
\hline cubic yards & 0.76456 & cubic meters & cubic meters & 1.308 & cubic yards \\
\hline \multicolumn{3}{|c|}{ Temperature } & \multicolumn{3}{|c|}{ Temperature } \\
\hline Fahrenheit & $\begin{array}{l}\text { subtract } 32 \\
\text { then } \\
\text { multiply by } \\
5 / 9 \text { ths }\end{array}$ & Celsius & Celsius & $\begin{array}{l}\text { multiply by } \\
9 / 5 \text { ths, then } \\
\text { add } 32\end{array}$ & Fahrenheit \\
\hline \multicolumn{3}{|c|}{ Energy } & \multicolumn{3}{|c|}{ Energy } \\
\hline kilowatt hour & 3,412 & $\begin{array}{l}\text { British thermal } \\
\text { unit }\end{array}$ & $\begin{array}{l}\text { British thermal } \\
\text { unit }\end{array}$ & 0.000293 & $\begin{array}{l}\text { kilowatt } \\
\text { hour }\end{array}$ \\
\hline kilowatt & 0.948 & $\begin{array}{l}\text { British thermal } \\
\text { unit per second }\end{array}$ & $\begin{array}{l}\text { British thermal } \\
\text { unit per second }\end{array}$ & 1.055 & kilowatt \\
\hline \multicolumn{3}{|c|}{ Force/Pressure } & \multicolumn{3}{|c|}{ Force/Pressure } \\
\hline $\begin{array}{l}\text { pounds per } \\
\text { square inch }\end{array}$ & 6.895 & kilopascals & kilopascals & 0.14504 & $\begin{array}{l}\text { pounds per } \\
\text { square inch }\end{array}$ \\
\hline
\end{tabular}

Source: Engineering Unit Conversions, M. R. Lindeburg, PE., Second Ed., 1990, Professional Publications, Inc., Belmont, California. 
DOE/RL-2000-72, Rev. 0

$11 / 2000$

This page intentionally left blank. 


\subsection{INTRODUCTION}

\footnotetext{
${ }^{1}$ Memorandum from J.J. Fiore and M.W. Frei, DOE/Washington, D.C. to R.T. French, DOE/Office of River Protection, and K.A. Kline, DOE/Richland Operations Office, dated October 25, 1999, Disposal Authorization Statement for the Hanford Site Low-Level Waste Disposal Facilities.
} 


\subsection{BACKGROUND}

The Low-Level Burial Grounds are located on the Hanford Site in the southeast corner of Washington and consist of 218-E-10 and 218-E-12B Burial Grounds in the 200 East Area and 218-W-3A, 218-W-3AE, 218-W-5, 218-W-4B, 218-W-4C, and 218-W-6 Burial Grounds in the 200 West Area. The Low-Level Burial Grounds consist of lined and unlined disposal trenches of various sizes and depths that began receiving waste in January of 1960 . The Low-Level Burial Grounds have been grouped into five waste management areas for Resource Conservation and Recovery Act (RCRA) of 1976 groundwater monitoring purposes. The waste management areas, corresponding burial ground designation, and approximate size of each area are shown in Table 2.1. Locations of the waste management areas are shown in Figure 2.1. Detailed burial ground site descriptions are provided in Chapter 3.0.

Table 2.1. Low-Level Waste Management Areas.

\begin{tabular}{|c|l|c|}
\hline Area & \multicolumn{1}{|c|}{ Burial Ground } & Hectares \\
\hline \hline 1 & $218-\mathrm{E}-10$ & 38.2 \\
\hline 2 & $218-\mathrm{E}-12 \mathrm{~B}$ & 70.1 \\
\hline 3 & $218-\mathrm{W}-3 \mathrm{~A}$ & 20.4 \\
& $218-\mathrm{W}-3 \mathrm{AE}$ & 20.0 \\
& $218-\mathrm{W}-5$ & 34.0 \\
\cline { 2 - 3 } & Total & 74.4 \\
\hline \multirow{2}{*}{4} & $218-\mathrm{W}-4 \mathrm{~B}$ & 3.5 \\
& $218-\mathrm{W}-4 \mathrm{C}$ & 20.9 \\
\cline { 2 - 3 } & Total & 24.4 \\
\hline 5 & $218-\mathrm{W}-6$ & 18.0 \\
\hline
\end{tabular}

The following sections provide a brief overview of Hanford Site history, the environmental setting, burial ground locations, dose-concentration relationships from the performance assessments, and approach used to select specific constituents of interest for inclusion in this supplemental monitoring plan.

\subsection{ENVIRONMENTAL SETTING}

The Hanford Site was established in 1944 as a U.S. government nuclear materials production facility. During its history, the Hanford Site mission has included nuclear reactor operation, storage, and reprocessing of spent nuclear fuel, and management of the associated waste generated. Present activities primarily involve waste management and environmental restoration. The inactive fuel reprocessing facilities and the radioactive waste management facilities are located in the 200 East Area and 200 West Area. 


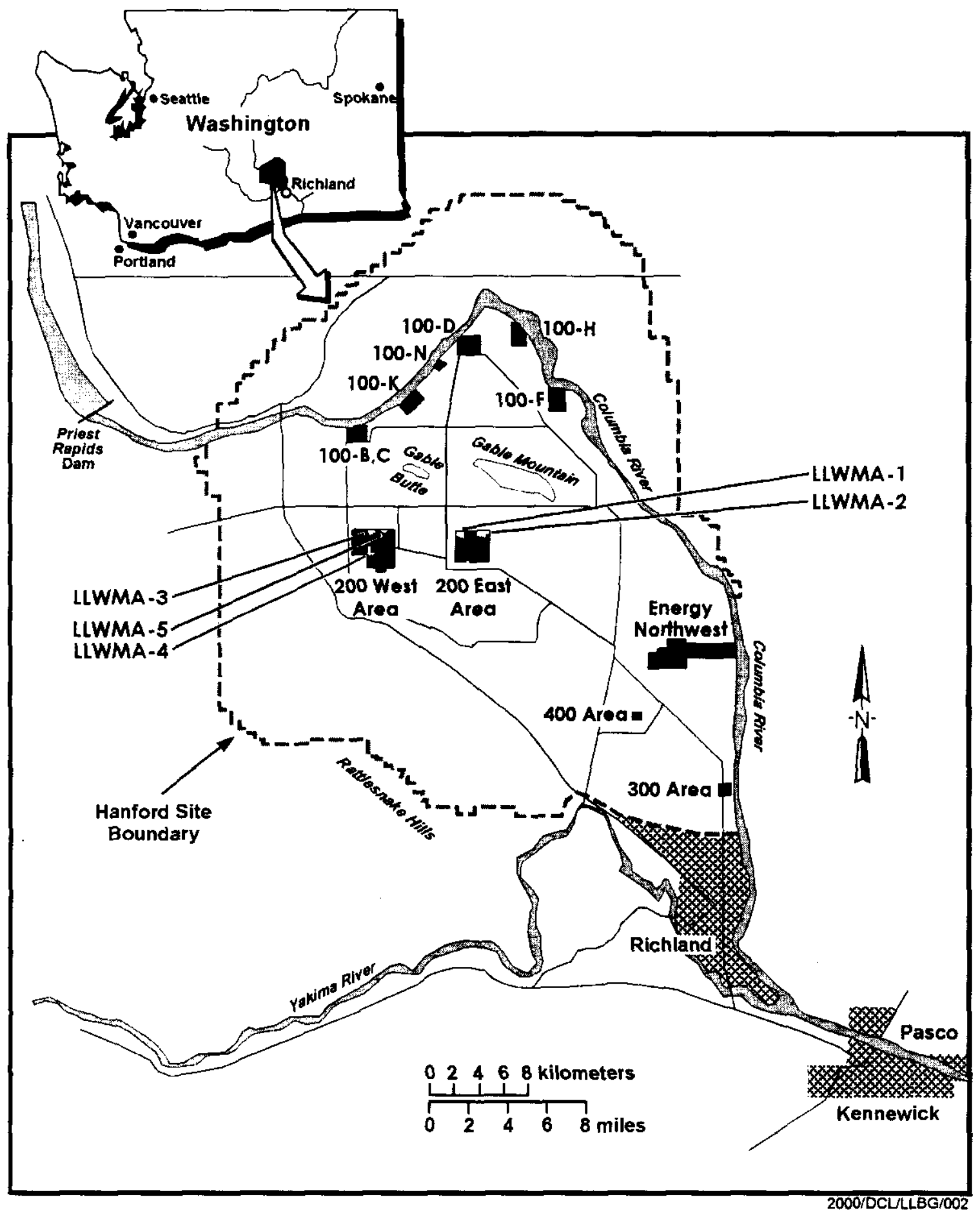

Figure 2.1. Location of 200 East and 200 West Area Low-Level Waste Management Areas on the Hanford Site. 


\subsubsection{Site Geography and Demography}

The Hanford Site is located in a structural and topographic depression of the Columbia Plateau called the Pasco Basin. The northern and eastern boundaries of the Hanford Site generally follow the Columbia River. The southern boundary generally is bounded by the Rattlesnake Hills and by the Yakima River (Figure 2.1). The Hanford Site covers an area of 1,450 square kilometers, extending into Benton, Franklin, Grant, and Adams counties. The nearest population center consists of three small cities (Richland, Kennewick, and Pasco) that are situated to the southeast of the Hanford Site on the Columbia River. Use of the Hanford Site is controlled institutionally by DOE for national security and health and safety reasons. In 1997, DOE transferred management of the Fitzner/Eberhardt Arid Lands Ecology Reserve, a 665-square kilometer area in the westem part of the Hanford Site, to the U.S. Fish and Wildlife Service. In addition, the U.S. Fish and Wildlife Service manages the Wahluke Slope Area and the Saddle Mountains National Wildlife Refuge, north of the Columbia River for the DOE. In 2000, the U.S. President established the Hanford Reach National Monument at the Hanford Site (Proclamation 7319 of June 9, 2000). This designation is consistent with the Hanford Comprehensive Land-Use Plan Record of Decision Environmental Impact Statement (DOE 1999). The 200 Areas are designated as an "Industrial-Exclusive" use area.

\subsubsection{Site Climatology and Meteorology}

Meteorological data have been collected at the Hanford Meteorology Station, located between the 200 East Area and the 200 West Area, since 1945. Temperature and precipitation data have been recorded in the region since 1912. The climate of the Pasco Basin can be classified as midlatitude semiarid or midlatitude desert with an average rainfall of about 16.8 centimeters per year, nearly half of which occurs in the months of November through January. Summers are warm and dry with abundant sunshine.

The annual average temperature on the Hanford Site is $12^{\circ} \mathrm{C}$. July is typically the warmest month with an average temperature of $25^{\circ} \mathrm{C}$. January tends to be the coolest month with an average temperature of $0^{\circ} \mathrm{C}$. December is the wettest month, receiving, on average, 2.6 centimeters, and July is the driest month receiving, on average, only 0.46 centimeter. Total annual snowfall, which includes all frozen precipitation, varies from a low of 0.76 centimeter to 142 centimeters. The average annual snowfall is 38 centimeters.

Dust and blowing dust (locally resuspended) occur frequently, with blowing dust the most commonly observed. Dust and blowing dust are recorded at the Hanford Meteorological Station when horizontal visibility is reduced to 9.65 kilometers or less. The average number of days per year with dust or blowing dust is 5 . The greatest number of days with dust or blowing dust in any month was 9 in May 1980, just after the Mt. St. Helens eruption. Dust and blowing dust occur most frequently between March and May and again in September and occur least frequently during November and December.

A graphical representation of wind direction data for the Hanford Site in the form of wind roses is given in Figure 2.2. The wind rose data indicate that the prevailing winds of the area are from the west-northwest and secondarily from the southeast. Average wind speeds are about 10 to 15 kilometers per hour. For hours of unstable directions, wind from the west-northwest and northwest sectors occur more frequently than the other directions. Winds are more frequently from the west-northwest during stable conditions. 


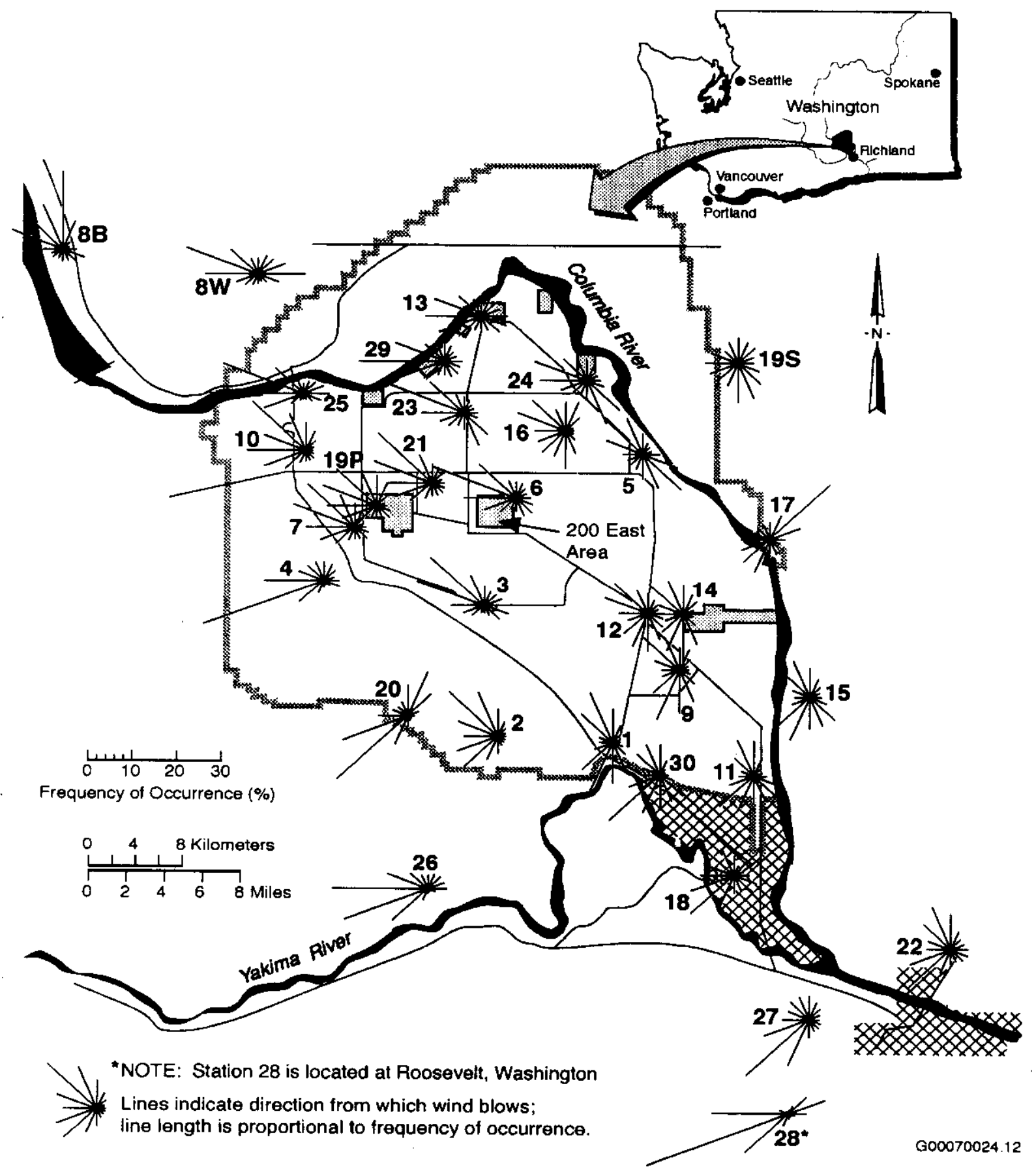

Figure 2.2. Hanford Meteorological Monitoring Network Wind Roses at 10-Meter Level, 1982 Through 1999 (from Hoitink et al. 2000). 


\subsubsection{Hydrogeology}

The Hanford Site lies within the Pasco Basin of the Columbia Plateau. The bedrock in this region is characterized by a thick sequence of flood basalts of the Columbia River Basalt Group. These basalts have been subsequently folded and faulted, forming broad structural and topographic basins separated by asymmetric anticlines. The basalts are overlain by sediment that accumulated in the basins. The suprabasalt sediment consists primarily of the following:

- Fluvial-lacustrine clays, sands, silts, and gravels of the Neogene-age Ringold Formation

- The Plio-Pleistocene unit made up of alluvial, eolian, and paleosol deposits

- Pleistocene cataclysmic flood deposits of the Hanford formation, composed of consolidated gravel, sand, and silt.

A thin layer of eolian and alluvial Holocene deposits of silt, sand, and gravel cover much of the Hanford Site. Generalized stratigraphy of the Hanford Site can be found in Williams et al. (2000, Figure 3.1).

The hydrology of the Hanford Site can be divided into two major aquifer systems: the basalt (and its related interbed system) and the suprabasalt system. The basalt/interbed aquifer system is composed of a series of rubbly basalt flow tops and, where present, interbeds of sedimentary origin. These aquifers are separated by dense basalt flow interiors. The suprabasalt aquifer forms the uppermost aquifer beneath the Hanford Site. This aquifer lies in the Ringold Formation and the overlying Hanford formation. The aquifer is generally unconfined; however, there are some confined or semiconfined portions of the aquifer in the Ringold Formation. There are also highly localized zones of perched water in the Ringold Formation, the Plio-Pleistocene unit, and the Hanford formation.

Groundwater occurs both within the upper unconfined aquifer system and within a system of deeper confined to semi-confined aquifers in the basalt flow tops, flow bottom zones, and sedimentary interbeds (DOE 1988, vol. 2, page 3.6-1). These deeper aquifers are intercalated with aquitards, consisting of basalt flow interiors (colonnades and entablatures). The general direction of groundwater flow is from the natural recharge areas west of the Hanford Site to discharge areas, primarily toward the Columbia River.

Recharge of the confined basalt aquifers occurs through infiltration on the anticlinal ridges bounding the Pasco Basin and from westward flow in basalt aquifers beneath the Columbia Plateau. Sources of natural recharge to the uppermost-unconfined aquifer system are infiltration and runoff of precipitation and runoff on the reaches of the Yakima and Columbia Rivers. The movement of precipitation through the vadose zone has been studied at several locations on the Hanford Site (Gee 1987; Routson and Johnson 1990; Rockhold et al. 1990; Fayer et al. 1991), with the general conclusions being that very little, if any, infiltration occurs where the soil is relatively fine grained and deep-rooted vegetation is present. Where soil is coarse and vegetation is shallow rooted or not present, infiltration can exceed 50 percent of the precipitation.

Artificial recharge to the uppermost aquifer occurs principally from DOE-RL's wastewater disposal practices at surface facilities within the 200 East and 200 West Areas. Two of the largest recharge mounds have developed beneath the 200 West and 200 East Areas at U-Pond and B-Pond, respectively. Under U-Pond, which was decommissioned in 1985, the water table had risen in excess of 26 meters after 40 years of operation. The mound under B-Pond has risen more than 9 meters (Graham et al. 1984). These facilities are associated with wastewater disposal from fuel and waste processing activities, and receive or have received treated liquid effluents of varying chemical characteristics. Liquid effluent is disposed at the 200 East Area Treated Effluent Disposal Facility. Treated effluent that includes tritium, which cannot be removed, is disposed at the State-Approved Land Disposal Site located north of the 
200 West Area. With decreasing discharges to the groundwater, the water table at these artificial mounds is decreasing.

\subsubsection{Hydrogeology of the 200 East Area}

The Low-Level Burial Grounds are located in the highly variable geologic setting of the 200 Areas plateau on the Hanford Site. The primary reference for the geologic interpretation is Lindsey et al. (1994). The information in that report is based on the data collected during the long history of drilling that has taken place in and around the 200 Areas (Tallman et al. 1979; Bjornstad 1984; Last et al. 1989; Barton et al. 1990; Goodwin and Bjornstad 1990; Mercer 1993a, 1993b, 1994).

The suprabasalt sediment in the 200 East Area consists of the Hanford and Ringold Formations. Ringold Formation sediment is generally not present beneath the northern half of this area. The Elephant Mountain Member of the Saddle Mountains Basalt is the uppermost basalt unit beneath the 200 East Area.

Groundwater flow in the 200 East Area is strongly influenced by the past disposal of large quantities of liquid waste to the 216-B-3 pond system (also called B-Pond). A large groundwater mound that developed under B-Pond essentially reversed the pre-Hanford (west to east) flow direction in the northern portion of the 200 East Area. The volume of liquid disposed to the B-Pond system has been reduced in recent years, allowing the groundwater mound to dissipate somewhat, thus reducing the groundwater gradient. The water table is entirely within the sands and gravels of the Hanford formation in the northern portion of the 200 East Area. The general west to east flow direction across the 200 East Area locally is modified by the B-Pond groundwater mound. For example, there is an inferred northwest to southwesterly flow in the northern 200 East Area that is expected to return to an easterly direction as the groundwater mound dissipates.

\subsubsection{Hydrogeology of the 200 West Area}

The 200 West Area is underlain, from the surface to the top of the basalt, by the Hanford formation, the Plio-Pleistocene unit, and the Ringold Formation. The Plio-Pleistocene unit in this area consists mostly of carbonate-cemented alluvial and eolian facies.

Groundwater flow in the 200 West Area is also influenced by past disposal practices. The pre-Hanford groundwater flow was predominantly west to east; however, liquid discharged to the 216-U-10 pond (also known as U-Pond and decommissioned in 1985) and other disposal facilities created a substantial groundwater mound ( 25 meters) in the southern part of the 200 West Area. This mound has since dissipated to $\sim 15$ meters. The water table beneath the entire 200 West Area is in the Ringold Formation. Perched water is possible on carbonate-rich layers in the formation, but because of the presence of numerous lateral discontinuities such as pinchouts and fractures, the lateral distribution of perched water (if any) is limited. The base of the unconfined aquifer beneath the 200 West Area is generally considered to be the lower mud unit of the Ringold Formation. Groundwater flow is to the northeast in the northern portion of the 200 West Area, shifting to an easterly to southeasterly direction. As the U-Pond groundwater mound dissipates, the general flow direction is expected to return to an easterly direction across the entire 200 West Area. Localized perturbations in flow direction occur because of pump and treat operations. 


\subsection{APPROACH LINKING PERFORMANCE ASSESSMENT AND OPERATIONAL MONITORING}

The waste disposal authorization for the Hanford Site Low-Level Burial Grounds is based (in part) on the postclosure performance assessments for the Low-Level Burial Grounds. To establish a meaningful link between operational monitoring and postclosure performance assessments, differences as well as similarities in the following factors need to be considered:

- Inventory

- Infiltration

- Sample media.

\subsubsection{Inventory and Constituents of Concern}

Performance assessments for the Low-Level Burial Grounds considered only the inventories of waste disposed since September 26, 1988, and the projected and final inventories (until closure) that are regarded as mobile in groundwater. But for purposes of the operational monitoring period, the inventories prior to 1988-to-present must be used. The primary radionuclides contributing to dose from groundwater contamination identified in the performance assessment and composite analysis are carbon-14, chlorine-36, iodine-129, selenium-79, technetium-99, and uranium-238. Because the mobile constituents identified in the performance assessment are the same key contaminants for both operational and postclosure conditions, the approach is to select those mobile constituents in each burial ground that would contribute most of the hypothetical groundwater pathway dose $(>99 \%)$ if breakthrough to groundwater were to occur. For this purpose, the inventories of the key mobile constituents identified in the performance assessment were taken from the closure plan (DOE 2000), which included the pre-1988 contributions. The total curie quantities were divided by their corresponding derived concentration guides for drinking water (DOE Order 5400.5) to obtain relative hazard index values (Appendix A). Those constituents that contributed greater than $0.1 \%$ of the total relative hazard were selected as target analytes. This approach assumes that all of the mobile constituents identified in the performance assessment have equal probability of migrating from the burial grounds (e.g., all have a $\mathrm{K}_{d}$ of 0 ). Based on this approach, the analytes that need to be included in the monitoring program for the groundwater network are shown in Table 2.2 . 


\begin{tabular}{|c|c|c|c|}
\hline Waste Management Area ${ }^{(a)}$ & Burial Grounds & Constituent List ${ }^{(b)}$ & Standard ${ }^{(c)}$ \\
\hline LLWMA-1 & $218-\mathrm{E}-10$ & $\begin{array}{l}\text { Uranium } \\
\text { Technetium-99 }\end{array}$ & $\begin{array}{l}20 \mu \mathrm{g} / \mathrm{L} \\
4,000 \mathrm{pCi} / \mathrm{L}\end{array}$ \\
\hline LLWMA-2 & $218-\mathrm{E}-12 \mathrm{~B}$ & $\begin{array}{l}\text { Uranium } \\
\text { Technetium-99 } \\
\text { Iodine-129 }\end{array}$ & $\begin{array}{l}20 \mu \mathrm{g} / \mathrm{L} \\
4,000 \mathrm{pCi} / \mathrm{L} \\
20 \mathrm{pCi} / \mathrm{L}\end{array}$ \\
\hline LLWMA-3 & $\begin{array}{l}218-W-3 A \\
218-W-3 A E \\
218-W-5\end{array}$ & $\begin{array}{l}\text { Uranium } \\
\text { Technetium-99 } \\
\text { lodine-129 }\end{array}$ & $\begin{array}{l}20 \mu \mathrm{g} / \mathrm{L} \\
4,000 \mathrm{pCi} / \mathrm{L} \\
20 \mathrm{pCi} / \mathrm{L}\end{array}$ \\
\hline LLWMA-4 & $\begin{array}{l}218-W-4 B \\
218-W-4 C\end{array}$ & $\begin{array}{l}\text { Uranium } \\
\text { Technetium-99 } \\
\text { lodine-129 }\end{array}$ & $\begin{array}{l}20 \mu \mathrm{g} / \mathrm{L} \\
4,000 \mathrm{pCi} / \mathrm{L} \\
20 \mathrm{pCi} / \mathrm{L}\end{array}$ \\
\hline \multicolumn{4}{|c|}{$\begin{array}{l}\text { (a) LWMA-5 is not listed because no waste has been disposed in this area. } \\
\text { (b) Constituents were derived based on relative hazard index values (Appendix A, Tables A.la and A.1b) and will } \\
\text { be supplemented to RCRA monitoring lists. } \\
\text { (c) Based on } 1 / 25 \text { of the derived concentration guide for ingested water from DOE Order } 5400.5 \text {. Concentration } \\
\text { assumed to yield an annual dose equivalent of } 4 \mathrm{mrem} / \mathrm{yr} \text {. For uranium, EPA proposed drinking water standard } \\
\text { of } 20 \mu \mathrm{g} / \mathrm{L} \text { is used. }\end{array}$} \\
\hline
\end{tabular}

Although carbon-14 was a significant percentage of the inventory in two burial ground waste management areas, carbon-14 was excluded as a likely groundwater pathway contributor in Low-Level Waste Management Area 2 because (1) carbon- 14 is contained in decommissioned U.S. Navy defueled reactor compartments that are self-contained and the source is irradiated carbon steel and (2) in Low-Level Waste Management Area 3, carbon-14 is contained in concrete and not likely to leach. Also, the high carbonate content of the vadose zone should act as a sink or would at least significantly retard any carbon-14 that did leach from the burial ground. Also, chemical uranium is used for routine monitoring purposes in the RCRA groundwater program as a more economical method (ultraviolet fluorescence) than alpha energy analysis. Under most Hanford Site conditions, $20 \mu \mathrm{g} / \mathrm{L}$ of chemical uranium is equivalent to $15 \mathrm{pCi} / \mathrm{L}$ of uranium-234, uranium-235, and uranium-238, combined.

\subsubsection{Infiltration Conditions}

Infiltration and the drainage of moisture through the vadose zone beneath the burial grounds are expected to be much greater during operations than after closure (Figure 2.3). During the operational period, runoff can accumulate in depressions and open trenches. Although unlikely, under unfavorable conditions (e.g., unusual precipitation event), migration to groundwater could occur in a relatively short time (estimated at 50 to 100 years in Wood et al. 1995, 1996). This is more likely in the 200 East Area burial grounds where the vadose zone is in the Hanford formation (course sands and gravel). If breakthrough occurs during the operational period, it could indicate possible weak points in the waste management system that might need special attention for closure. During the postclosure period, the infiltration barrier would nearly eliminate such a driving force. Thus conditions during the operational phase can be thought of as a 'worst case scenario' for performance assessments. 


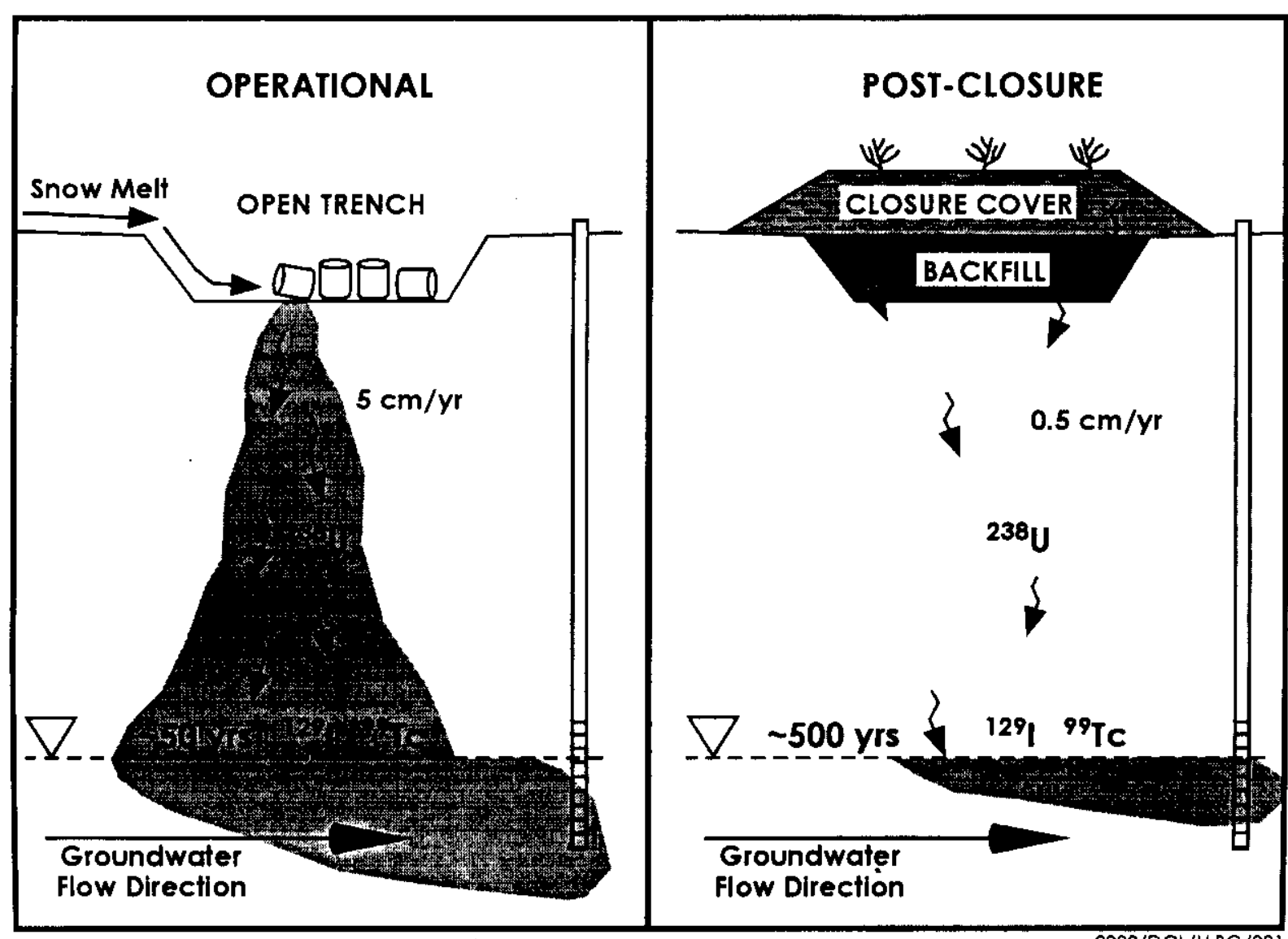

Figure 2.3. Conceptual Model of Contaminant Migration under Operational and Post-Closure Conditions.

Possible weak points noted include structural failures. For example, collapse of boxes and containers that have large void spaces could create depressions and openings for collection of snow melt. Such depressions and/or openings would result in enhanced infiltration that could shorten the travel time to groundwater considerably from the estimated rate of 50 to 100 years (based on a uniform infiltration rate of $5 \mathrm{~cm} / \mathrm{yr}$ ).

There is an existing program to inspect burial grounds for cave-in areas (Section 4.3). Corrective action for infiltration control as well as for personnel safety is accomplished by backfilling, grooming, and contouring to both cover the cave in and to minimize infiltration. As part of this plan (Section 7.0), results of the existing routine inspection program will be used to alert management to indications of potential longer term problems that might require preventive measures to control or reduce the chance of infiltration before closure. For example, contouring to eliminate ponding of snowmelt over the covered areas of the burial grounds is a longer term preventive measure.

\subsubsection{Sample Media}

As discussed in Chapter 4.0, the primary pathways of interest are air and groundwater. These are common to both operational and postclosure conditions. The goals are to use the existing air and groundwater monitoring programs to the maximum extent possible. In Chapter 3.0 , the location of 
1 existing groundwater wells for each of the waste management areas are identified. Constituents and 2 sampling frequency for the existing RCRA program are listed in Appendix D. The existing sampling 3 schedules, as discussed later, will be supplemented to meet the needs of the performance assessment 4 monitoring plan. The location of all existing air monitoring stations, both onsite and offsite, are discussed 5 in Section 4.1. 


\subsection{BURIAL GROUND SITE DESCRIPTIONS}

Two of the low-level waste management areas are located in the 200 East Area and three are located in the 200 West Area as previously discussed (Figure 2.1). The Low-Level Burial Grounds are regulated under Subtitle C, Hazardous Waste Management of RCRA and the Washington State Dangerous Waste Regulations (WAC 173-303). Although both radioactive and chemical wastes have been placed in the burial grounds, emphasis for this plan is limited to the radioactive component. Brief descriptions of each burial ground, including a site map showing monitoring well locations, disposal history, and site-specific hydrogeology, are provided in the following sections. Locations of specific trenches and waste types are shown in Appendix B. Selected groundwater contaminant plume maps in the 200 East and 200 West Areas are shown in Appendix C. Additional discussion of monitoring wells, sampling frequency, and constituents analyzed is provided in Appendix D and Section 4.2.

\subsection{LOW-LEVEL WASTE MANAGEMENT AREA 1}

This waste management area consists of a single burial ground, 218-E-10 (Figure 3.1) and is located in the northwestern corner of the 200 East Area. The northern portion of this area (Figure 3.1) is currently unused. The southern portion contains a total of 13 unlined trenches with a north-south orientation and two other stub trenches at the southeast corner with an east-west orientation. The trenches are typically $V$-shaped excavations $\sim 4.5$ meters deep and vary in length from $\sim 230$ to 425 meters. Trench 1 is 7.3 meters deep with a bottom width of 4.5 meters. The east-west trench also has a bottom width of 4.5 meters and is only 30.5 meters long. These unlined trenches are excavated into the natural surface materials that consist of coarse gravel, cobbles, and boulders, with some interstitial sand. Generally, these trenches are excavated with $1: 1$ to $1: 1.5$ side slopes.

\subsubsection{Disposal History}

Disposal operations began in 1960 and continue to the present. Waste disposed to this low-level waste management area comes from the Plutonium-Uranium Extraction (PUREX) Plant, B Plant, and $\mathrm{N}$ Reactor. The waste consists primarily of remote handled, failed equipment, and mixed industrial waste (Maxfield 1979). The east-west trench contains 69 hot cell cover blocks and four centrifuge blocks. The tops of the bails of these blocks might be only 48 centimeters below grade. The hazardous materials disposed include lead and asbestos in unknown volumes. The radiological constituents include carbon-14, activation products, mixed fission products, uranium, and plutonium. This burial ground does not contain any retrievably stored transuranic waste. 


\subsubsection{Hydrogeology}

The suprabasalt sediment in this area consists entirely of the Hanford formation. Ringold Formation deposits are not present beneath this low-level waste management area, though boreholes adjacent to the BX-BY tank farms encountered a thin sequence of Ringold-like deposits. Data from the boreholes that reach the top of the basalt beneath the burial ground indicate the basalt dips to the west and south. The thickness of the Hanford formation in this area ranges from 70 to 100 meters.

The direction of groundwater flow in this portion of the 200 East Area is difficult to determine using water-level data alone. Differences in hydraulic head are generally on the order of 0.1 meter across the entire low-level waste management area, and there does not appear to be any predominant flow direction. Measurement and other uncertainties completely mask any elevation differences in head measurements. Information from contaminant plumes suggest that the groundwater flow is generally to the northwest. Future plans include application of a downhole device to determine flow direction directly.

The saturated thickness of the Hanford formation beneath this low-level waste management area ranges from 3 meters in the northeast to 14 meters in the south. Testing at the time of borehole installation was used to determine the hydraulic conductivity values and results ranged from 73 to 762 meters per day. In many cases, testing was inconclusive. 


\subsection{LOW-LEVEL WASTE MANAGEMENT AREA 2}

3 This waste management area consists of a single burial ground, 218-E-12B (Figure 3.2), located in the 4 northeastern corner of the 200 East Area. This burial ground is an active landfill that began receiving 5 waste in 1967, and currently contains a total of 40 unlined trenches. The trenches run generally north-south and vary in length from 90 to 580 meters. These V-shaped trenches are excavated to a depth of $\sim 5$ meters. This burial ground includes a large, special-purpose trench (Trench 94) for disposal of defueled nuclear reactor compartments from decommissioned U.S. Navy vessels. Disposed reactor compartments are regulated as state-only mixed waste. Trench 94 is a large rectangular trench excavated to a depth of 18 meters with bottom dimensions of $\sim 250$ by 100 meters. A graded ramp provides access to the trench floor.

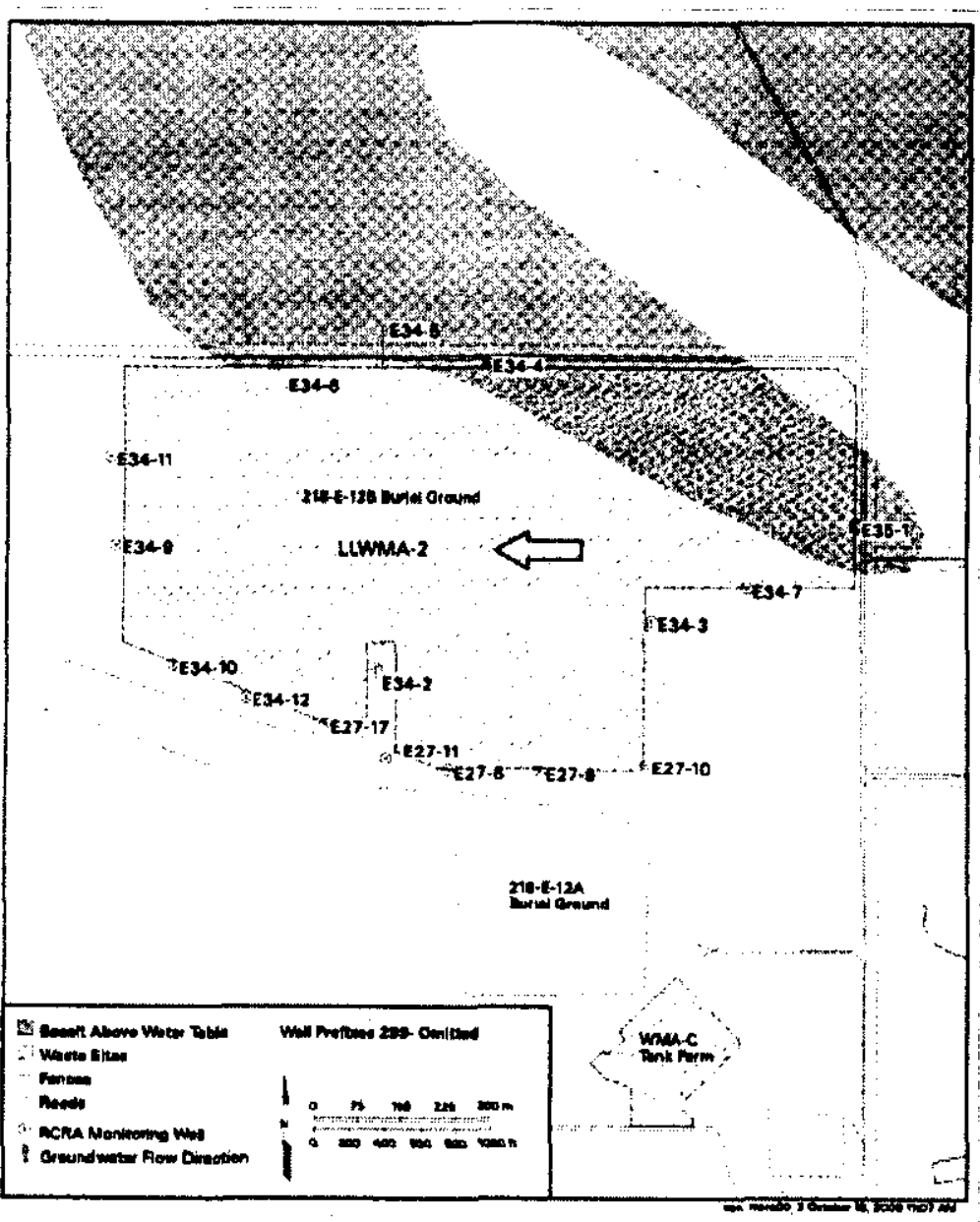

Figure 3.2. Low-Level Waste Management Area 2. 
The material excavated from the construction of the trenches is used to back fill and cover the disposed waste. The excavated material consists primarily of large gravel, cobbles, boulders, and sand. Some portions of this waste management area have been covered with an additional 0.6 meter of finer-grained soil and have been revegetated with shallow-rooted plants.

\subsubsection{Disposal History}

Disposal operations began in 1967 at this waste management area and continue to the present. The majority of the waste volume in the 218-E-12B Burial Ground was disposed before 1987. The disposed waste has been listed as miscellaneous dry waste (Maxfield 1979). Retrievably stored transuranic waste is present in some of the trenches. Trench 94 receives large defueled reactor compartments. Radiological constituents include carbon-14, activation products, and plutonium.

\subsubsection{Hydrogeology}

The Hanford formation is the sole suprabasalt unit beneath this waste management area. In this area, the basalt ranges from 57 to 80 meters thick. The top of the basalt gently dips to the south beneath the area. The top of the basalt represents an erosional surface, scoured by Pleistocene cataclysmic floods, and is gently undulating with enclosed depressions 3 to 4.5 meters deep. A much deeper depression in the basalt, $\sim 12$ meters deep, is inferred to exist just to the north of the site (Graham et al. 1984; Last et al. 1989).

Groundwater flow beneath this low-level waste management area is predominantly east to west and is influenced by liquid discharges to the B-Pond system located along the eastern side of 200 East. Flow direction will change as the mound from past wastewater discharges dissipates. This shift might already be underway near Low-Level Waste Management Area 2. Groundwater flow beneath this area is further complicated by the existence of a basalt high that extends above the water table in the northern and eastern portions of the area. The saturated aquifer thickness ranges from 0 meter in the north and east to 7.5 meters in the south. Hydrologic testing conducted during well construction had limited success in this area and, as at Low-Level Waste Management Area 1, the results were variable (hydraulic conductivities ranged from 427 to 2,042 meters per day).

\subsection{LOW-LEVEL WASTE MANAGEMENT AREA 3}

This waste management area, consisting of three burial grounds: $218-\mathrm{W}-3 \mathrm{~A}, 218-\mathrm{W}-3 \mathrm{AE}$, and $218-\mathrm{W} 5$ (Figure 3.3), located in the north-central portion of the 200 West Area. 218-W-3A Burial Ground consists of 57 unlined disposal trenches that vary in length from 120 to 285 meters. The $218-\mathrm{W}-3 \mathrm{AE}$ Burial Ground consists of eight unlined trenches that vary in length from 325 to 380 meters with bottom widths of 2 to 30 meters. A minimum of 2.5 meters of backfill has been placed over the waste. The 218-W-5 Burial Ground consists of 10 unlined trenches and two lined trenches. The unlined trenches are approximately 160 to 350 meters long, 4.5 to 20 meters wide, and 5 to 6 meters deep. An expansion area consisting of five trenches is planned (DOE 2000).

\subsubsection{Disposal History}

The 218-W-3A Burial Ground began operation in 1970 and received shipments described as miscellaneous transuranic and nontransuranic waste from the Three Mile Island accident cleanup; irradiated fuel elements from the General Electric Company's Vallecitos, California, facility; radioactive 
soil from a salt waste spill (encased in concrete burial boxes); and industrial waste. The $218-\mathrm{W}-3 \mathrm{AE}$ Burial Ground was placed in operation in 1981. Waste includes miscellaneous (e.g., rags, paper, rubber gloves, disposable supplies, broken tools, etc.) and industrial waste (e.g., failed equipment, tanks, pumps, ovens, agitators, heaters, hoods, jumpers, vehicles, and accessories).

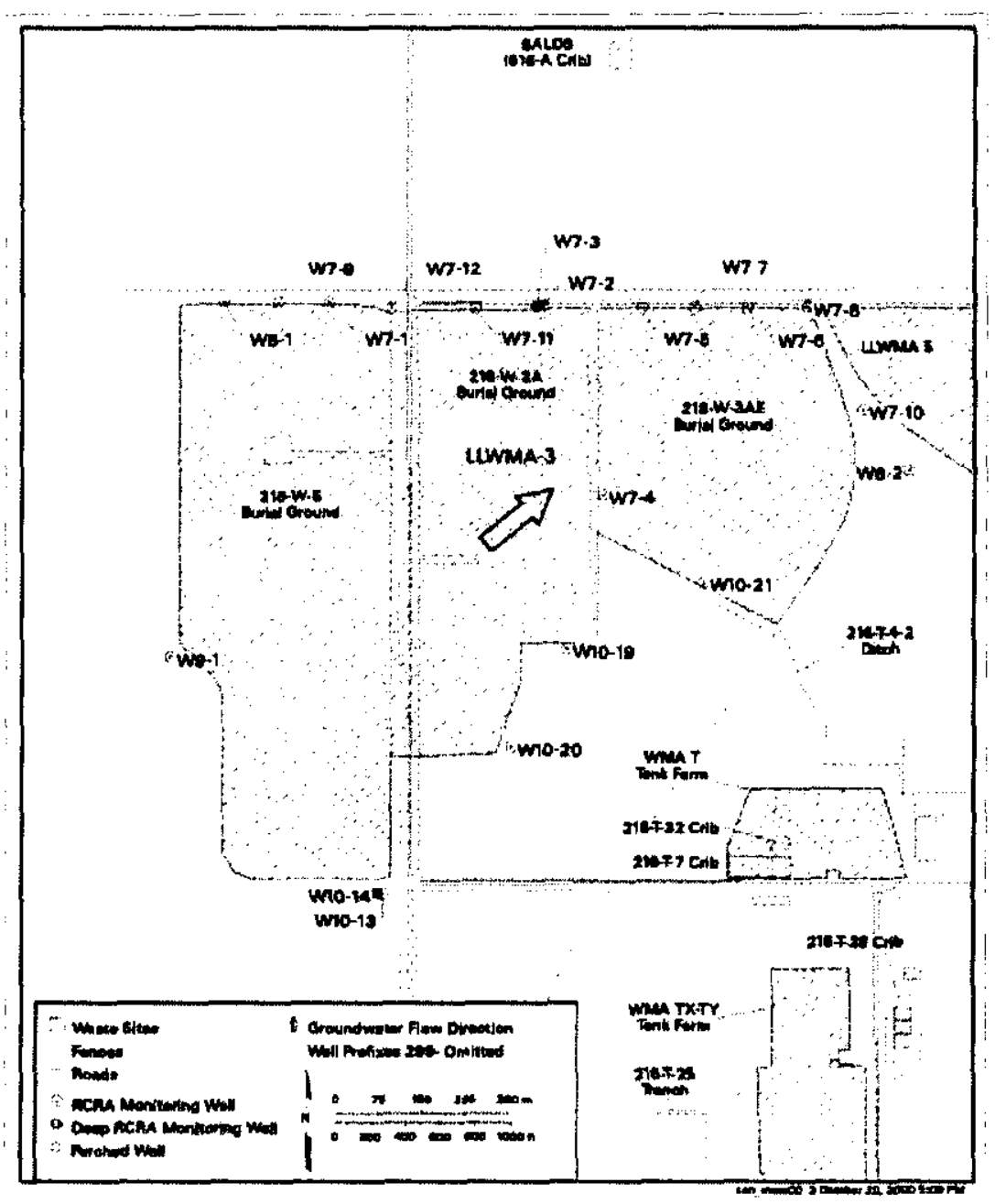

Figure 3.3. Low-Level Waste Management Area 3.

The 218-W-5 Burial Ground was placed in operation in 1986. This burial ground received packaged waste materials from 200 West Area operations and other waste from onsite and offsite. Radiological constituents consist of mixed fission products, activation products, transuranics, uranium, and carbon-14 (encased in concrete) dependant on radiological inventory.

The saturated thickness of the uppermost aquifer beneath this waste management area is $\sim 68$ meters in the south and 78 meters in the north where the Ringold lower mud unit is absent. The hydraulic conductivity values calculated for the wells completed in the upper portion of the unconfined aquifer varied from $2.0 \mathrm{E}-02$ to 9.8 meters per day. The average hydraulic conductivity is 1.5 meters per day. 


\subsection{LOW-LEVEL WASTE MANAGEMENT AREA 4}

This low-level waste management area, consisting of two burial grounds, $218-\mathrm{W}-4 \mathrm{~B}$ and $218-\mathrm{W}-4 \mathrm{C}$

(Figure 3.4) is located in the south-central portion of the 200 West Area. The 218-W-4B Burial Ground contains 13 unlined trenches. The 218-W-4C Burial Ground contains 15 unlined trenches. Less than half of the trenches have asphalt pads. The asphalt pads and trenches have been designated as retrievable storage units for transuranic waste. These storage units have asphalt bottoms or fire-retardant plywood placed on the bottom. Plywood is also placed on the top of and in between the layers of the stacked waste. A layer of heavy plastic and a minimum of 1.2 meters of soil are then placed over the filled portions of the storage units.

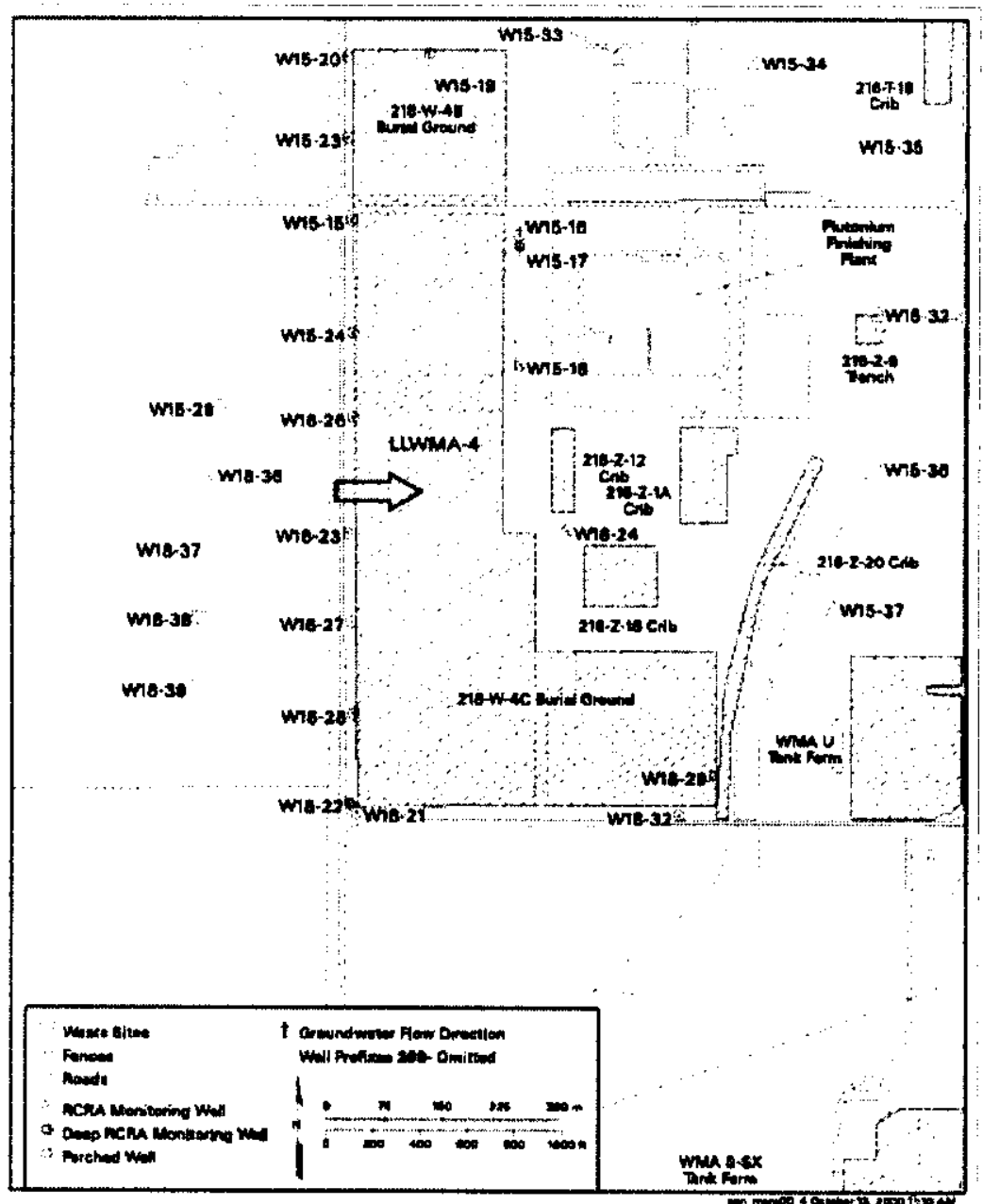

Figure 3.4. Low-Level Waste Management Area 4.

\subsubsection{Disposal History}

17 The 218-W-4B Burial Ground began receiving waste in 1967 (Maxfield 1979) and contains a total of 13 trenches. This waste is described as miscellaneous solid mixed waste and was received from several sources on the Hanford Site, including 100-C, 100-N, 200 West, and 300 Area. Tweive belowgrade 
caissons occurred between 1969 and 1990 . Two trenches are filled with retrievably stored transuranic waste.

The 218-W-4C Burial Ground began receiving waste in 1978 and is still active. One trench at the north end is a dedicated trench for disposal of Navy defueled reactor components. Seven trenches contain retrievably stored transuranic waste.

\subsubsection{Hydrogeology}

The stratigraphic units beneath this area are similar to those beneath Low-Level Waste Management Area 3. The Plio-Pleistocene unit underlies the entire area and is up to 12 meters thick, is generally thickest to the north and west, and thins to the east and south. Beneath the area, the top of the Plio-Pleistocene unit is very irregular with only a minor overall dip to the south. Perched water is possible locally on carbonate-rich layers in the unit, but because of the presence of numerous lateral discontinuities such as pinchouts and fractures, the lateral distribution of perched water probably is limited.

The groundwater flow patterns beneath this low-level waste management area have been strongly influenced by the past and present disposal activities in the vicinity. At the beginning the RCRA monitoring program (ca 1991) flow was east to west with a northwest component in the northern portion of the area. Further complicating the determination of groundwater flow direction is the pump-and-treat program initiated in August 1996 in the 200-ZP-1 Groundwater Operable Unit. This program is intended to contain the highest concentrations of the carbon tetrachloride plume beneath the 200 West Area. Extraction wells to the east and injection wells to the west of this waste management area have reversed the groundwater flow direction beneath this area. Additional perturbations are expected as pumping wells are shutdown. Once the new flow patterns have stabilized, the network will be re-evaluated to determine the number and optimum location for new monitoring wells to increase the coverage on the east (new downgradient side) of this waste management area.

The saturated thickness of the Ringold Formation above the lower mud unit varies from 68 meters at well 299-W15-17 to 75 meters at well 299-W18-22. The average hydraulic conductivity for the upper portion of this aquifer is 24 meters per day. The entire sedimentary sequence in this area ranges from 165 to 172 meters thick.

\subsection{LOW-LEVEL WASTE MANAGEMENT AREA 5}

This low-level waste management area contains the 218-W-6 future burial ground (Figure 3.5) and is located in the north-central portion of the 200 West Area. This area has not yet received any waste and is reserved for future mixed waste disposal. Groundwater monitoring (for regulatory compliance purposes) has not been conducted at this site since 1996. However, co-sampling with other facilities (Low-Level Waste Management Area 3, single-shell tank waste management area T, State-Approved Land Disposal Site) to track a tritium plume and sitewide monitoring activities is currently performed.

This area is underlain by essentially the same stratigraphic units that underlie Low-Level Waste Management Area 3 to the west. The Ringold Formation in this area has well-cemented zones that can generate locally confined conditions beneath the water table that have the potential to generate local perched-water conditions in the vadose zone. The total thickness of the sedimentary units above the basalt in this area ranges from 141 to 148 meters. 
Groundwater flow beneath this area is generally to the northeast. Hydrologic conditions are similar to those found at Low-Level Waste Management Area 3, which is located immediately to the west. The saturated thickness of the uppermost aquifer is $\sim 60$ to 65 meters. The best estimate of hydraulic conductivity is 12 meters per day.

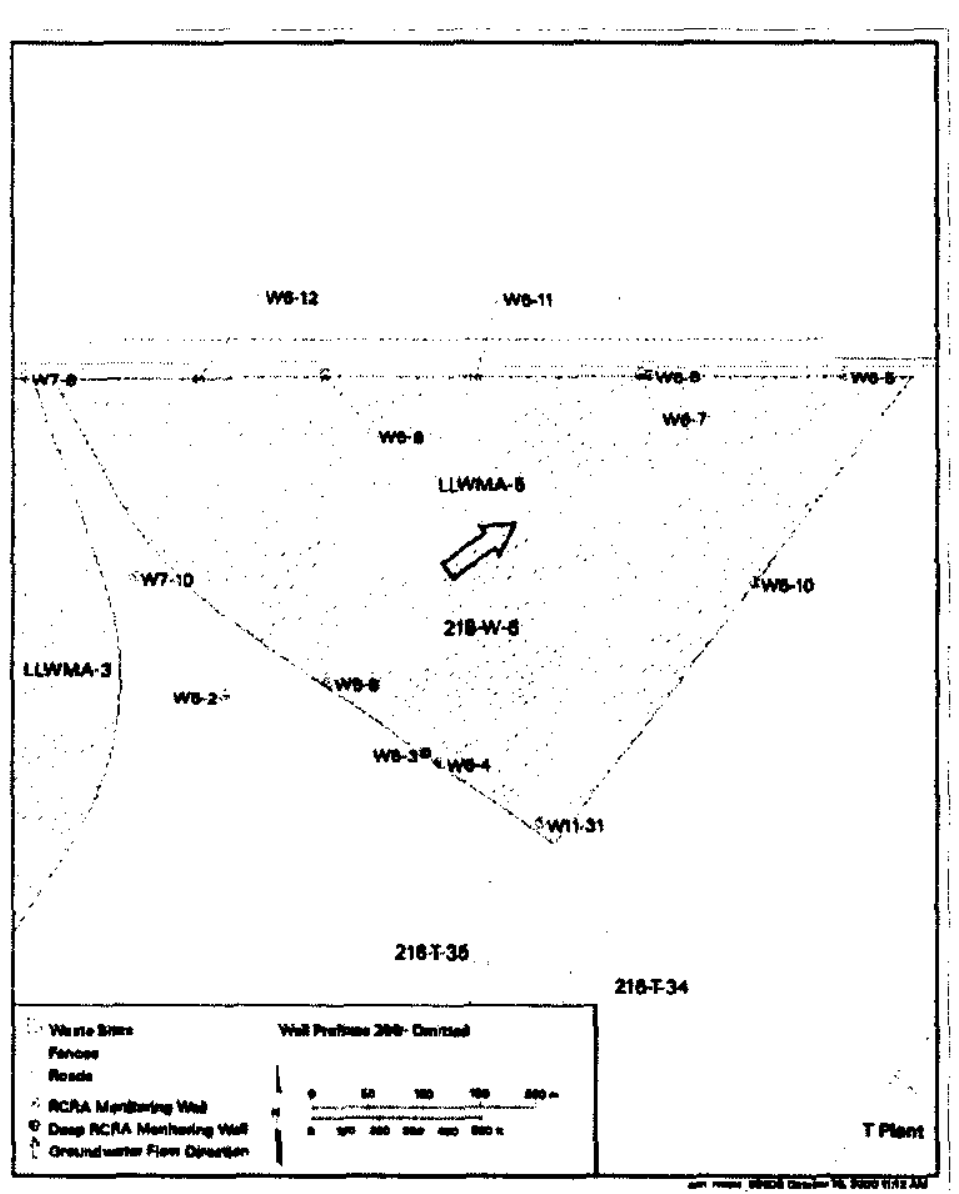

Figure 3.5. Low-Level Waste Management Area 5.

\subsection{GROUNDWATER CONTAMINANT PLUMES}

Past practice disposal of wastewater to the ground resulted in extensive plumes of mobile constituents in the 200 West and 200 East Areas. Tritium, technetium-99, iodine-129, and nitrate plumes for the 200 Areas are shown in Appendix C. Some of the existing contaminant plumes encroach on the Low-Level Burial Grounds sites. The most significant encroachment is at Low-Level Waste Management Area 1 in the northwest corner of 200 East. Most of this waste management area lies within the $1-\mathrm{pCi} / \mathrm{L}$ contour of the iodine- 129 plume (Figure $\mathrm{C} .1$ ) and the $2,000-\mathrm{pCi} / \mathrm{L}$ contour of the tritium plume (Figure C.2). The $5-\mathrm{pCi} / \mathrm{L}$ contour for iodine-129 crosses the northern end of the area. Technetium-99 (900-pCi/L contour) also appears to cross the northeast corner of Low-Level Waste Management Area 1 (Figure C.3). Thus, evaluation of performance assessment monitoring results for this burial ground must take existing contaminant concentrations into account. At some point in the future, all groundwater flow is expected to change to an easterly direction in the 200 East Area.

In contrast to the 200 East Area, existing groundwater contaminant plumes currently appear to bypass Low-Level Waste Management Areas 3 and 4 in the 200 West Area (Figures C.5 to C.8). Nitrate and 
1 tritium are present beneath all the 200 West Area burial grounds, however these constituents are not of 2 concern for performance assessment monitoring purposes. Also, flow direction is gradually shifting from 3 the north-northeast to the east (the normal or pre-Hanford Site flow direction), which will carry the 4 existing contamination away from the 200 West Area burial grounds in the future. 
This page intentionally left blank. 


\subsection{EXISTING MONITORING}

This section describes existing air and groundwater monitoring programs, including current sampling schedules, locations, and the additional monitoring needed to meet the objectives of this supplemental plan. The existing monitoring programs will be supplemented with the constituents identified in Section 2.2. The basic approach is to use the existing air monitoring program and to supplement the existing groundwater program with selected performance related constituents of interest. The 218-W-5 Burial Ground contains two RCRA-compliant mixed waste trenches with liner and leachate collection systems. The systems are monitored for any operational effluent releases to verify compliance with RCRA requirements. Methods of monitoring, sampling, sample analysis and reporting, along with associated action levels, will be described in a future update to this monitoring plan.

\subsection{AIR PATHWAY MONITORING}

The quality of the air is measured at a large number of surveillance locations across and along the perimeter of the Hanford Site. This network consists of two types: the Near-Field Facility Environmental Monitoring Program and the Environmental Surveillance Program. At the present time, the near-field facility environmental monitoring program is managed by Fluor Hanford, whereas the sitewide surveillance program is managed by Pacific Northwest National Laboratory (PNNL). A description of the program is provided in the Environmental Monitoring Plan, United States Department of Energy, Richland Operations Office (DOE 1997). Information from the near-facility air monitoring program and the sitewide surface surveillance program are provided to PNNL for inclusion in the annual Hanford Site environment report (e.g., Poston et al. 2000).

\subsubsection{Near-Facility Environmental Monitoring Program}

Near-facility air sampling monitors are used to determine the effectiveness of the facility controls and effluent treatment systems in reducing effluents and emissions. These air samplers also measure ambient diffused source emissions. During 1999, a network consisting of 85 sampling locations were used to monitor near-facility conditions across the Hanford Site.

A total of 40 near-facility air sampling locations were operated in the 200 East and West Areas in 1999. Nineteen of these units were operated in the general vicinity of 200 East Area Low-Level Burial Grounds and 21 were operated in the vicinity of the 200 West Area Low-Level Burial Grounds. Both upwind and downwind monitoring locations exist around the burial grounds. However, the close proximity of other waste management activities makes it difficult to separate the contributions from multiple potential sources. Specific locations of all the monitoring stations are included in Perkins et al. 2000, Figures 2.7 and 2.8. Additional monitoring stations might be necessary to supplement the existing stations where coverage is sparse or where it might be necessary to distinguish between a Low-Level Burial Ground and adjacent sources.

Near-facility air sampling monitors operate with a continuous flow rate of 0.056 cubic meter per minute drawing air through a 47 -millimeter open-faced filter that is placed approximately 2 meters above the ground. The filters are exchanged biweekly, held for 1 week to allow for decay of short-lived natural radioactivity and sent to the analytical laboratory for analysis of total alpha and total beta activity. The gross radioactivity measurements are used to indicate changes in trends in the near-facility environment. The filters are stored until the end of either a 3- or 6-month period, segregated, and combined into composite by sample station for specific radionuclide analyses (e.g., isotopic uranium-234, -235 , and -238 ) as shown in Perkins et al. 2000, Table 2.1. 
The collection and handling of all data from the near-facility air sampling monitoring network is controlled by the "NESHAP Quality Assurance Project Plan for Radioactivity Air Emissions" (HNF-EP-0528-3). Also, as required by the facility safety basis document (HNF-SD-WM-ISB-002), trench air monitoring is conducted during bulk waste disposal operations.

\subsubsection{Sitewide Surface Environmental Surveillance Program}

The primary purpose of the sitewide environmental surveillance program is to demonstrate compliance with DOE Order 5400.1. A key element in DOE-RL's compliance program is the Hanford Federal Facility Agreement and Consent Order [(Tri-Party Agreement) Ecology et al. 1998] that brings into play all CERCLA and RCRA requirements including corrective action. In addition, the Washington State Department of Heaith oversees and in many ways regulates the release of airborne radioactivity on the Hanford Site.

In conjunction with the near-facility air sampling monitoring network, a sitewide environmental surveillance program is operated by PNNL. This program has operated continuously for many years. During 1999, the network of sitewide air monitoring units numbered 44. During 1999, 23 of the sampling locations were on the Hanford Site, 11 of the locations were on the Hanford Site perimeter, 8 in nearby communities, and 2 in distant communities (Figure 4.1). Examples of nearby communities are Benton City, Richland, Kennewick, and Pasco. The two distant communities are Yakima and Toppenish. Samples were collected continuously and filters were exchanged every 2 weeks. Analytes of interest included total alpha, total beta, tritium, and iodine-129. Gross alpha and gross beta samples were collected and analyzed every 2 weeks, tritium samples were collected and analyzed every 4 weeks, and iodine-129 samples were collected every 4 weeks, combined into a quarterly composite sample and analyzed for each location. The sitewide surveillance program is anticipated to continue to demonstrate compliance with DOE Order 5400.1.

\subsection{GROUNDWATER MONITORING}

The existing network of groundwater monitoring wells, sampling frequency, and constituents analyzed are summarized in Appendix D (Tables D.1 through D.4). Well location maps are presented in Chapter 3.0.

Under the RCRA interim status monitoring, the wells are routinely sampled semi-annually for the general contamination indicator parameters (specific conductance, $\mathrm{pH}$, total organic carbon and total organic halides) and for groundwater quality and site-specific parameters except for phenol that is sampled annually (Appendix D). The constituents of interest (iodine-129, technetium-99, and uranium) for this performance assessment-based supplemental plan are not routinely analyzed for RCRA groundwater monitoring purposes (i.e., for interim status detection monitoring). For example, only uranium is routinely sampled for Low-Level Waste Management Area 1 and iodine-129 and technetium-99 in selected wells of Low-Level Waste Management Area 4. However, some Low-Level Burial Grounds network wells and/or analytes are co-sampled with other waste unit investigations that include technetium-99 (e.g., the groundwater quality assessment conducted for the B-BX-BY tank farm waste management area located immediately east of Low-Level Waste Management Area 1 in the 200 East Area). 


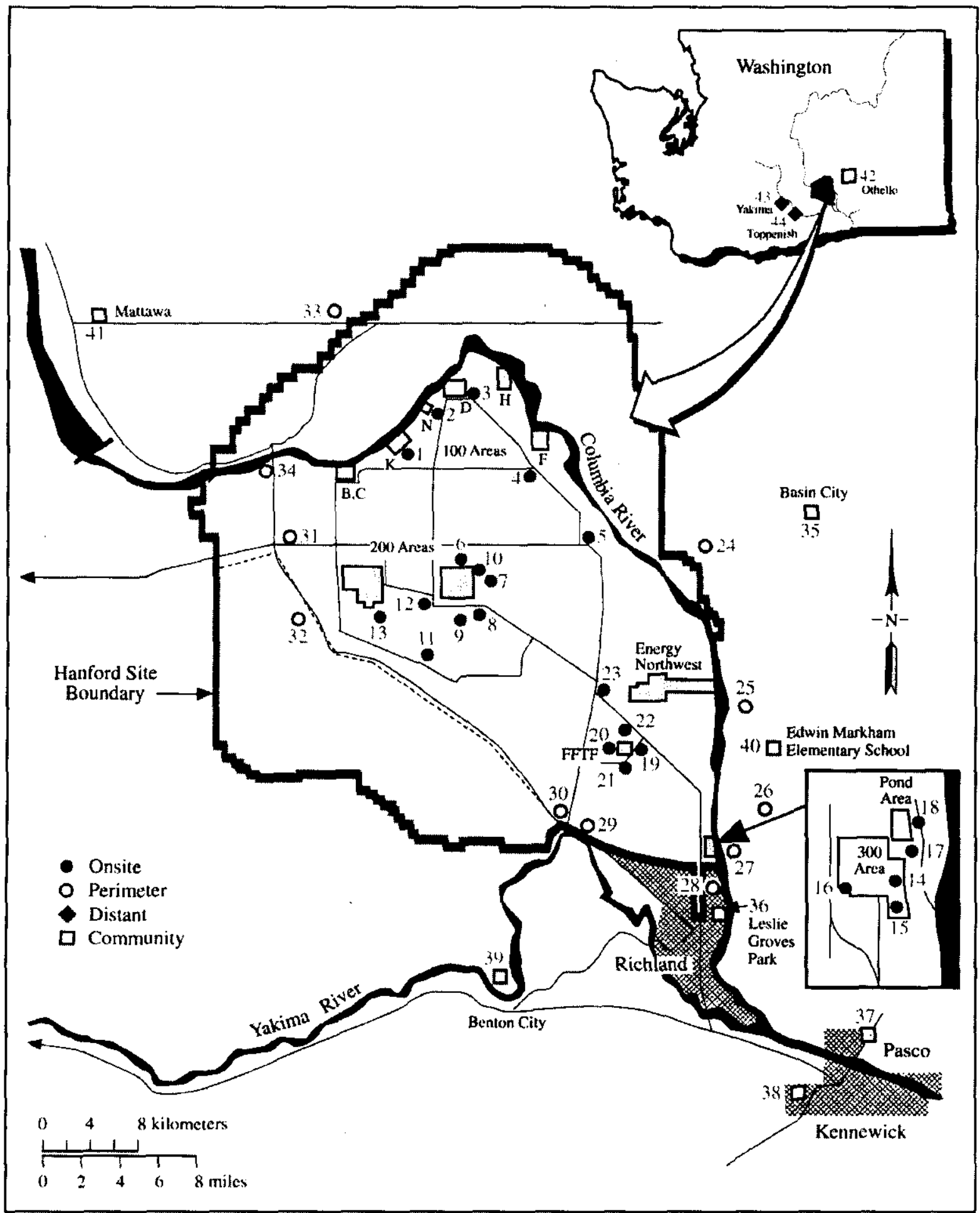

Figure 4.1. Air Surveillance Sampling Locations, 1999 (PNNL-13230). 
As groundwater mounds due to past wastewater discharges continue to dissipate, changes in the direction of groundwater flow are occurring. As the water table continues to decline, the upper aquifer (above the basalt basement rock) will no longer exist beneath much of Low-Level Waste Management Area 2. In other areas, additional monitoring wells might be needed to adjust to the change in flow direction and to replace monitoring wells that have and will be going dry as the water table drops. These factors are reviewed by DOE-RL and their contractors as well as the regulators to ensure compliance with state and federal RCRA groundwater monitoring requirements. For the purposes of this plan, it is assumed that existing monitoring networks for RCRA requirements, as modified to meet changing conditions, will be adequate.

\subsection{SUBSIDENCE MONITORING AND CONTROL}

Subsidence controls have been implemented at the Low-Level Burial Grounds to provide operator safety and to reduce radiological risk, thereby protecting human health and the environment. Through subsidence monitoring and control, low areas that could form catchments can be identified and managed with the goal of reducing infiltration.

\subsubsection{Operating Practices}

Over the years, all active burial grounds have accepted some quantity of bulk waste (e.g., contaminated vegetation and contaminated equipment) as well as packaged waste. The nature of the packaged waste varies. Packaging forms have included steel drums and boxes, wood pallets, plywood and cardboard boxes, and reinforced concrete high-integrity containers for stabilization of Category 3 waste. Drummed and boxed wastes are commonly co-mingled in many trenches. In some cases, trenches have been used exclusively to dispose of contact-handle or remote-handle waste. Historical operating practices have not included a procedural requirement to segregate the various types of waste. Furthermore, the waste containers were not compacted nor was attention given to void space that might exist in the various packages, though current disposal practices limit the amount of void space allowed. Containerized waste is typically stacked in the bottom of each trench using either cranes or forklifts. Bulk contaminated soil and debris are typically dumped from the trench lip down a working face.

Once the waste has been placed in the trench, the waste is covered with native soil. A minimum of 2.5 meters is currently placed over disposed waste although the thickness of this cover has varied over the years. This depth of cover is required to minimize concerns associated with bio-intrusion.

\subsubsection{Inspection and Maintenance}

No systematic effort was made to compact trench fills. In addition, the deterioration of packaging and void volume in disposed containers has been the source of some local settlement. The combined effect of these two processes has resulted in surface subsidence and on occasion cave-ins at some locations in the Low-Level Burial Grounds. As a result, weekly inspections are now performed in the burial grounds to identify those locations that might require maintenance. These inspections are performed to protect personnel from injury and to make sure that if subsidence does occur that a radiation or contamination exposure pathway has not been created.

All information resulting from these inspections is placed in the facility operating record as outlined in the inspection procedure. The data from these inspections are used as a basis to decide the appropriate remediation and for purposes of trend analysis. Remediation typically consists of backfilling the cave-in with native soil. The identification, recording, and backfilling (as needed) of subsidence areas have 
become routine activities. Low-bulk density and the ongoing decomposition of waste packaging present significant long-term stability issues. Therefore, the practice of inspection and maintenance will continue throughout operations and is expected to continue through closure and postclosure.

The inspection program can also be used to alert management to indications of longer term drainage and settling problems. Appropriate action can be taken to divert surface runoff away from the covered areas of the burial grounds and to minimize accumulation in open trenches. In this way, the ongoing or existing inspection program can also be used to address performance assessment monitoring and corrective action needs (e.g., to reduce or control infiltration during the operational period). Reporting and evaluation of this information is described in Chapter 7.0. 
DOE/RL-2000-72, Rev. 0

$11 / 2000$

This page intentionally left blank. 
U.S. DOE Order 5400.1 General Environmental Protection Program and DOE Order 5400.5, Radiation Protection of the Public and the Environment establish requirements and standards for environmental protection program across the Hanford Site. It is DOE's objective to ensure that operations on the Hanford Site comply with applicable federal, state, and local environmental laws and regulations (DOE Order 5400.1) and to protect members of the public and the environment against undue risk from radiation (DOE Order 5400.5). The collection and reporting of air and groundwater quality information are an integral part of this program. The overall objective for monitoring is to ensure that Low-Level Burial Grounds are monitored for compliance with conditions of the disposal authorization statement and to verify that Low-Level Burial Grounds are meeting the performance objectives (Table 1.1) of DOE Order 435.1 . Specifically, the limits of $4 \mathrm{mrem} / \mathrm{yr}$ for water resource protection and the $10 \mathrm{mrem} / \mathrm{yr}$ for air emissions (excluding radon) are used to assess whether continued performance of Low-Level Burial Grounds is in compliance with the requirements that all DOE radioactive waste is managed in a manner that protects the environment and personnel and public health and safety. Figure 5.1 depicts the general process that will be used to establish the baseline that can be used for future comparisons for the list of radiological constituents identified in Section 2.2.1.

\subsection{GROUNDWATER}

Groundwater monitoring on the Hanford Site is an integral part of the Environmental Monitoring Plan (DOE 1997). This plan integrates monitoring at active waste disposal facilities to comply with requirements of RCRA and Washington State regulations, as well as operational monitoring around nuclear facilities and environmental surveillance to comply with DOE Order 5400.1 .

\subsubsection{Latabliabing Baseliese Conditions}

To develop an effective baseline for future comparisons (detection of a release) and to identify any trends (sources of temporal and/or spatial variation) in the sampling data, a review of available data for the past 5 years will be performed (i.e., as an initial task to implement this plan). If temporal and/or spatial variation are present in the data, separate baseline values might be needed. The goal of the statistical evaluation is to ensure that enough data are collected to obtain adequate estimates of the central tendency and variation in background for each radiological constituent of interest. In cases where the constituents of interest have not been routinely analyzed in the network wells, constituents will have to be added to the list and collected based on the existing sampling frequency (i.e., semiannually for 4 years) to obtain the minimum number of independent samples (e.g., $n=8$ ) required for each network well (e.g., control chart approach). Data might need to be transformed to fit the distributional assumption. After evaluation of monitoring data, baseline values will be established using the most appropriate statistical methods that will account for the nature of the data, the distributional assumption, and the percentages of nondetects. In general, the intent is to follow guidance in EPA (1992, pages 6-11 to 6-12) and Ecology (1996, page 65 ), which statistically defines background water quality (or baseline concentration) as the $95 \%$ upper tolerance interval with a $95 \%$ confidence. Baseline values will be updated when more data become available or site condition changes. 
DOE/RL-2000-72, Rev. 0

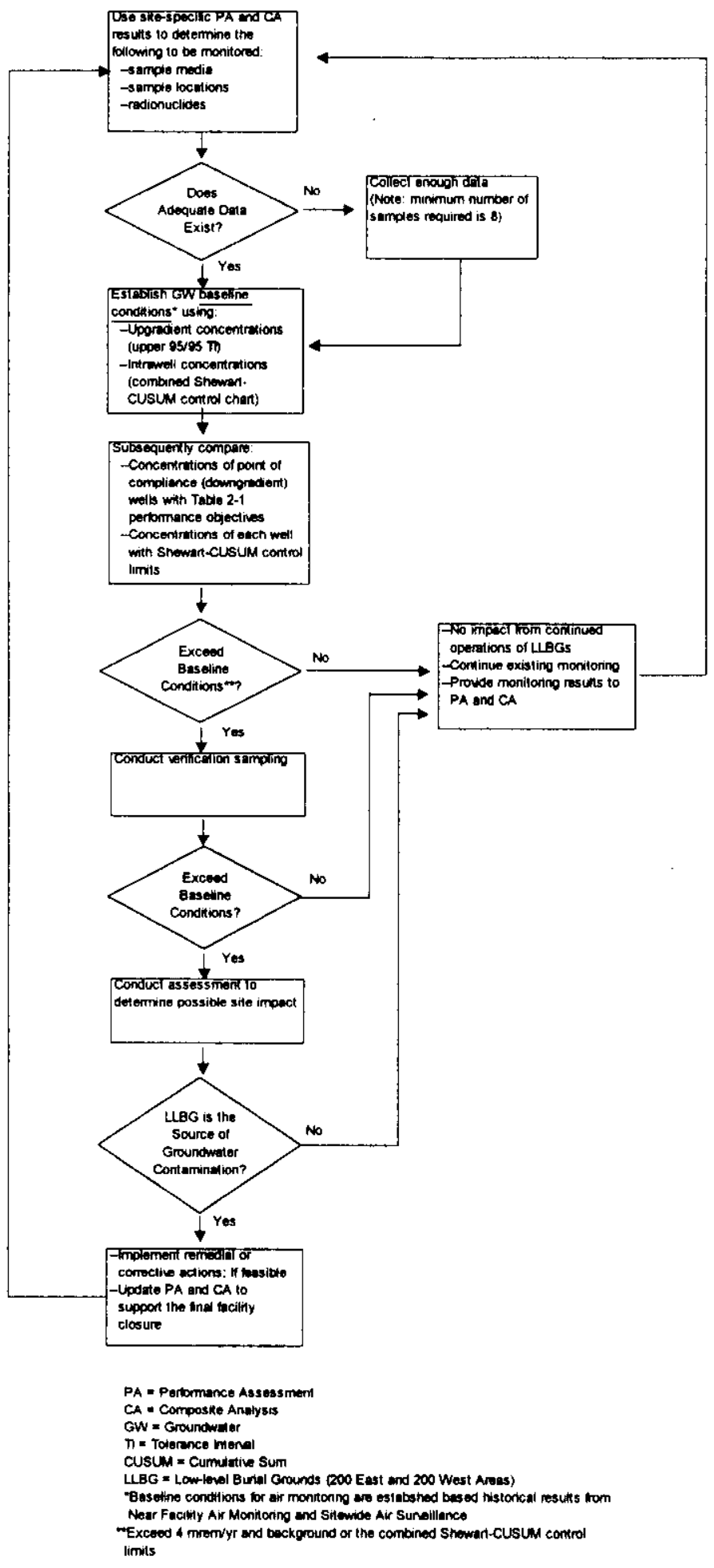

Figure 5.1. An Overview of the General Process Flow for Establishing Baseline Conditions and Evaluation for Compliance 
The tolerance interval defines a concentration range (from background or upgradient well data) that contains at least a specified proportion (coverage, perhaps $95 \%$ ) of the population with a specified probability (level of confidence, perhaps $95 \%$ ). There are two types of tolerance intervals: parametric and nonparametric. Parametric tolerance interval techniques are valid when the assumption that the data are drawn from a normal (or lognormal) population holds. When data are not normally or log-normally distributed, a nonparametric tolerance interval is used to estimate background values.

Parametric tolerance intervals are sensitive to the assumption that the data are normally distributed. The statistical tests used to evaluate whether or not the data follow a specified distribution are called goodness-of-fit tests. A recommended test is the Shapiro-Wilk test for normality of the data (Shapiro and Wilk 1965), which is considered to be one of the very best tests of normality available (Miller 1986; Mandansky 1988). The Shapiro-Wilk test statistic (W) will tend to be large when a probability plot of the data indicates a nearly straight line (i.e., normal distribution). Only when the plotted data show significant departure from normality will the test statistic be small. Hence, if the computed value of $\mathrm{W}$ is less than the critical value $\mathrm{W}_{\alpha}$ for a prechosen value of $\alpha$ (e.g., $\alpha=5 \%$ ) shown in statistical tables, the hypothesis of normality is rejected. Another method to assess the distributional assumption is the use of normal probability plot. This plot is simple to construct, yet useful for spotting irregularities in the data. The plot makes it easy to determine whether departures from normality are occurring in the mid-range of the data or in the extreme tails. Probability plots can also indicate the presence of possible outlier values that do not follow the basic pattern of the data and/or show the presence of significant positive or negative skewness.

If a lognormal (or a normal) distribution is a reasonable approximation of the upgradient concentrations, a parametric tolerance interval $(\mathrm{Tl})$ of the following form is calculated.

$$
\begin{gathered}
\mathrm{TI}=\overline{\mathrm{x}}_{\mathrm{b}} \pm \mathrm{kS}_{\mathrm{b}}(\text { two-sided }), \text { or } \\
\mathrm{TI}=\overline{\mathrm{x}}_{\mathrm{b}}+\mathrm{kS}_{\mathrm{b}} \text { (one-sided) }
\end{gathered}
$$

where $\overrightarrow{\mathrm{x}}_{\mathrm{b}}=$ background mean

$\mathrm{k}=\mathrm{a}$ normal tolerance factor, which depends on the number of background samples $(\mathrm{n})$, coverage $(P)$, and confidence level $(1-\alpha)$. A coverage of $95 \%$ and confidence of $95 \%$ are used. With $n=8, P=95 \%$, and $(1-\alpha)=95 \%, k$ is 3.188 for a one-sided normal tolerance interval (Gibbons 1994).

$\mathrm{S}_{\mathrm{b}}=$ background standard deviation.

If background concentration does not follow a lognormal or normal distribution or the proportion of nondetects is greater than $15 \%$, a nonparametric tolerance interval will be constructed. An upper one-sided nonparametric tolerance limit is the largest observation (Conover 1980). The sample size (n) needed to have $95 \%$ (i.e., $\alpha=5 \%$ ) confidence that the largest observation in the sample will cover at least $95 \%(\mathrm{P}=95 \%)$ of the population is 59 , which is obtained from the following equation (Hahn and Meeker 1991, pages $91-92)$ :

$$
\begin{aligned}
\mathrm{n} & =\log \alpha / \log \mathrm{P} \\
& =(\log 0.05 / \log 0.95) \\
& =58.4 \text { (rounded up to } 59) .
\end{aligned}
$$

Therefore, the background data set needs to be updated when more data become available because one is $95 \%$ sure that with eight background samples, the largest observation will only cover at least $68.8 \%$ (not 
$95 \%$ ) of the background population. That is, at most $31 \%$ of the background population will exceed the baseline value. When $n$ is 20 , the coverage will be increased to $86.1 \%$. When $n$ is 59 , the minimum coverage is $95 \%$. In general, this illustrates that if the underlying distribution of concentration values is unknown, more baseline samples are needed compared to the parametric case to construct a tolerance interval with sufficiently high coverage. It should be noted that a function of the monitoring program is to periodically re-evaluate the statistical tests being used. Therefore, the methods described will be reviewed during and after baseline data are collected to ensure the methods are the most appropriate, considering background conditions.

\subsubsection{Compliance with Performance Standards}

After a baseline value is established for each constituent of interest (Table 2.1), monitoring results from compliance (downgradient) wells will be compared to the performance standards shown in Table 1.1. If an exceedance is noted, verification sampling will be conducted to see whether the exceedance is caused by errors in sampling, laboratory analysis, or transcription. Verification sampling is currently the best available approach for balancing false positive and false negative error rates in groundwater monitoring applications (Gibbons 1994, page 15). If results from verification sampling confirm the initial exceedance, assessment monitoring will be conducted to determine whether the observed exceedance is likely caused by site impact. A comparison with background concentration (i.e., baseline values established in Section 4.1.1) is needed to evaluate whether the exceedance is caused by source(s) upgradient of the facility. If it is determined that a Low-Level Burial Ground is not the source of observed groundwater contamination, low-level waste can continue to be disposed at the sites without adverse effect on the public, personnel, and the environment. However, if it is determined that a Low-Level Burial Ground is the source of groundwater contamination, corrective actions might need to be developed to mitigate the release or potential release. In addition, based on the monitoring results, a determination of the continued adequacy of the performance assessment and composite analysis will be made.

\subsubsection{Trend Evaluation}

To conform with the requirement that the environmental program for low-lovel waste disposal facilities should be capable of detecting changing trends in performance to allow any necessary corrective action prior to exceeding the performance objectives, the combined Shewart-CUSUM control chart approach (ASTM 1996, EPA 1989, 1992, Gibbons 1994) will be performed at Low-Level Burial Grounds for constituents of interest identified in Table 2.1. The method is a sequential testing procedure to detect an upward shift in the mean concentration of a constituent of interest. The method can be implemented following a baseline of eight or more independent sampling periods for a given well. Because not all performance assessment constituents of interest are currently sampled for RCRA groundwater monitoring purposes and eight independent samples are the minimum required sample size, it is recommended that the number of samples needed for statistical evaluation be collected on an existing sampling frequency (i.e., semiannually for 4 years). The method assumes that the groundwater baseline data and future observations will be independent and normally distributed. The most important assumption is that the data are independent. The assumption of normality can usually be met by log-transforming the data or by other Box-Cox transformations. The Shewhart portion of the test checks for any sudden upward shift in groundwater quality parameters based on a single observation, while the CUSUM checks for any gradually increasing trend in the groundwater quality parameters.

The procedure can be implemented as follows: Let $x_{i}^{\prime}$ be a series of independent baseline observations $i=1, \ldots, b(b=8)$. Let $x_{i}$ be a series of future monitoring measurements $i=1,2,3 \ldots \ldots$. 
Then, using the baseline data, the following steps are applied.

1. First determine if the $\mathbf{x}_{i}^{\prime}$ can be assumed to follow a normal distribution with mean $\mu$ and standard deviation $\sigma$. If not, transform the $x_{1}^{\prime}$ using the appropriate Box-Cox transformation and work with the transformed data.

2. Next use the baseline data to compute the estimates

$$
\bar{x}^{\prime}=\sum_{i=1}^{b} x_{i}^{\prime} / \mathrm{b} \text { for } \mu \text { and } s^{\prime}=\sqrt{\sum_{i=1}^{b}\left(x_{i}^{\prime}-\bar{x}^{\prime}\right)^{2} /(b-1)} \text { for } \sigma \text {. }
$$

3. Determine the upper Shewhart control limit (SCL) for the procedure by calculating $S C L=\bar{x}^{\prime}+z_{s} s^{\prime}$ where $z_{s}$ is a percentile from the standard normal distribution used to set the false negative and false positive values of the Shewhart control limit. The value of $z_{\mathrm{s}}$ that is most often suggested for groundwater use is 4.5 by Lucas (1982), Starks (1989), and EPA (1989). Other values may also be used, depending on the sampling scheme used and whether verification sampling is used to modify the false positive and false negative error rates.

4. Determine the upper CUSUM control limit (CCL), with $C C L=\bar{x}^{\prime}+z_{c} s^{\prime}$. The value of $\mathbf{z}_{c}$ suggested by Lucas (1982), Starks (1988), and EPA (1989) is $z_{c}=5$. This value can also be adjusted to reach desired false negative and false positive error rates.

5. Determine the amount of increased shift in the mean of the water quality parameter of interest to detect an upward trend. This value is referenced as $\mathrm{k}$ and is usually measured in $\sigma$ units of the water quality parameter. Lucas (1982), Starks (1988), and EPA (1989) suggest a value of $k=1$ if there are less than 12 baseline observations and a value of $k=0.75$ if there are 12 or more baseline observations.

Using the monitoring data after the baseline measurements have been established:

6. Compute the CUSUM statistic as $S_{i}=\max \left\{0,\left(x_{i}-k s^{\prime}\right)+S_{j-1} s^{\prime}\right\}$ as each new monitoring measurement, $x_{i}$ becomes available, where $i=1,2,3, \ldots .$. and $S_{0}=0$

7. As each new monitoring measurement becomes available, compute the Shewhart and CUSUM tests; a verification sampling will be conducted if either $x_{i} \geq S C L$ or $S_{i} \geq C C L$. A well is declared to be out of control only if the verification result also exceeds the SCL or the CCL. If both $x_{i}<S C L$ and $S_{i}$ $<\mathrm{CCl}$, then continue monitoring.

If resampling is implemented during the monitoring, the analytical result from the resample is substituted into these formulas for the original value obtained, and the CUSUM statistic is updated. Note in the combined test, that the Shewhart portion of the test will quickly detect extremely large deviations from the baseline period. The CUSUM portion of the combined test is sequential; thus, a small shift in the mean concentration over the baseline period will slowly aggregate in the CUSUM statistic and eventually cause the test to exceed the CUSUM control limit CCL.

If an analytical result at a point-of-compliance well was above the control limit specified by the combined Sherwart-CUSUM method, a change in groundwater concentrations would be indicated. The triggering well would be resampled and the constituent in question re-analyzed. Adequate time would be allowed to elapse for the aquifer near the well to return to an unperturbed state. The recovery time needed to ensure statistical independence between sampling events is generally a few hours to a few days, depending on the groundwater flow rate and the size of the disturbed zone created during a typical well purging and sampling event. A statistically significant result would be declared only if the resample result is larger 
than the 'trigger value'. In that case, assessment sampling would be conducted to determine if the LLWMA is the source of groundwater contamination. If the LLWMA were identified as the source, corrective actions might need to be developed to mitigate the release or potential release. In addition, based on the monitoring results, a determination of the continued adequacy of the performance assessment and composite analysis will be made.

When significant trends in the background data are found, the source must be identified because these might be evidence of a prior impact from the site or offsite. If the source of the trend is found to be unrelated to the facility, an alternative constituent might be required for that well or all wells at the facility. In some cases, it might not be possible to differentiate between upgradient sources and a potential Low-Level Burial Ground source. For example, at Low-Level Waste Management Area 1, technetium-99 and uranium already exist in several upgradient and downgradient wells. The source in this case is attributed to the past-practice liquid waste disposal sites to the east and southeast. The flow direction in this area will eventually return to the natural eastward direction. So at some point in the future, it might again become possible to detect a burial ground source of technetium-99 and uranium. In the other burial grounds, the presence of existing constituents of concern is not expected. The approach in any case will be to evaluate potential upgradient source areas and source characteristics in relation to flow direction, past, and present contaminant plumes, groundwater flow rate and distance to the Low-Level Burial Ground in question. This will serve as a test of reasonableness for suspect upgradient sources.

\subsection{AIR PATHWAY}

As noted previously, DOE Order 5400.1 establishes the requirement for an environmental protection program across the Hanford Site. This program ensures that DOE operations on the Hanford Site comply with all applicable federal, state, and local environmental laws and requiremerts. The collection and reporting of air quality information conducted for near-facility environmental monitoring (Section 4.1.1), as well as surveillance monitoring (Section 4.1.2), is an integral part of this program. Compliance will be assessed by comparison of monitoring results with the air en.issions dose performance objective limit of $10 \mathrm{mrem} / \mathrm{yr}$ (excluding radon).

\subsubsection{Baseline}

Ambient air monitoring is conducted to determine baseline concentrations of radionuclides in the operational areas, to assess the impact of operations on the local environment, and to monitor diffuse and fugitive emissions from sources located within the operations area (i.e., near-facility air monitoring). These measurements also provide an indication of the performance of facilities managed by the Fluor Hanford and the Environmental Restoration Contractor and are used to demonstrate compliance with environmental protection criteria. Bi-weekly samples were collected from 40 sample locations ( 19 in the 200 East Area and 21 in the 200 West Area) and analyzed for total alpha and total beta activities. These initial analyses served as an indicator of potential problems. Quarterly or semiannually composite samples were collected for other site-specific radionuclides of concern (e.g., gamma energy analysis, strontium-90, isotopic uranium). Details concerning sampling locations as well as site-specific radiological constituents are provided in Appendix 2 of PNNL-13230. The continued monitoring and reporting of time series data from composites and bi-weekly samples establishes an ongoing baseline. Average concentrations of selected radionuclides were compared to performance standards and to samples measured in distant station (located at Wye Barricade, 600 Area). 


\subsubsection{Trends}

In addition to near-facility air monitoring, airborne radionuclide samples were collected at 44 continuously operating samplers: 23 on the Hanford Site, 11 near the site perimeter, 8 in nearby communities, and 2 in distant communities (Figure 4.1). Constituents of interest include total alpha, total beta, tritium, and iodine-129. Average concentrations at the site perimeter were compared to the levels measured at distant stations (Yakima and Toppenish) based on two-tailed t-test at $5 \%$ significant level ( $\log$ transformed values). In addition, airborne concentrations obtained from samples collected in the current year (e.g., fiscal year 1999) in the Hanford Site environs were compared to results collected during the previous years (e.g., fiscal years 1995 to 1998). Trends would be noted through these comparisons.

\subsubsection{Compliance with Performance Objectives}

Information from the near-facility air monitoring program and the environmental surveillance program are provided to PNNL for inclusion in the Hanford Site annual environmental report. PNNL uses this information to calculate offsite dose to the maximum exposed individual for inclusion in the annual report. This comparison is believed to provide a reasonable health risk comparison to the general public from the operation and disposal of radioactivity in the 200 East and West Area Low-Level Burial Grounds. For example, during 1999, the dose from all operations in the 200 Areas at the maximum exposed individual was calculated to be $3 \times 10^{-4} \mathrm{mrem} / \mathrm{yr}$ (Poston et al. 2000, Table 5.0.1) as compared to the Low-Level Burial Grounds air pathway performance objective of $10 \mathrm{mrem} / \mathrm{yr}$.

\subsection{CORRECTIVE ACTION}

The corrective action policy for exceeding the performance objective will be addressed by DOE-RL. The policy for corrective action, as it relates to any noncompliance associated with the disposal authorization, will be addressed within the context of DOE Order 5400.5 and DOE Order 435.1, Section IV, R.3.C. 
DOE/RL-2000-72, Rev. 0

$11 / 2000$

This page intentionally left blank. 


\subsection{QUALITY ASSURANCE AND QUALITY CONTROL}

Quality assurance and quality control (QA/QC) practices encompass all aspects of Hanford Site environmental monitoring and surveillance programs. Samples are collected and analyzed according to documented standard analytical procedures. Analytical data quality is verified by a continuing program of internal laboratory quality control, participation in inter-laboratory crosschecks, replicate sampling and analysis, submittal of blind standard samples and blanks, and splitting samples with other laboratories. More detailed descriptions of the air and groundwater QA/QC program can be found in the annual reports of the groundwater program (e.g., Hartman et al. 2000) and the annual Hanford Site environmental report (e.g., Poston et al. 2000). The groundwater report, which includes QC results and a description of the program, is available on the Internet at (http://hanford.pnl.gov/groundwater $/ g w r e p 99 / \mathrm{html} / \mathrm{start} \mathrm{l.htm)}$.

\subsection{GROUNDWATER QUALITY CONTROL RESULTS}

Severn-Trent, Inc. analyzes all routine groundwater samples for the Hanford Site Groundwater Monitoring Program. The vendor operates under contract through Fluor Hanford with technical oversight provided by PNNL. PNNL audits their internal QA/QC program and monitors performance with blind spikes, replicates, and audits. In 1999, uranium and technetium-99 in spiked groundwater samples were submitted to the laboratory quarterly and iodine- 129 was submitted semiannually. Of the 16 technetium- 99 and uranium-238 samples and six iodine-129 samples submitted as double-blind spikes, all were within control limits (within $\pm 30 \%$ of expected concentrations; Chapter 8, Poston et al. 2000).

The limits of quantitation (LOQ), based on blanks submitted to the vendor as samples in 1999, were $50 \mathrm{pCi} / \mathrm{L}$ and $1 \mathrm{pCi} / \mathrm{L}$ for technetium- 99 and iodine- 129 , respectively. The LOQ for chemical uranium was $0.1 \mu \mathrm{g} / \mathrm{L}$ (Hartman et al. 2000). These LOQs (lowest concentration for precise quantitative measurements, Miller and Miller 1988, page 116) are 20 to 200 times lower than the $1 / 25$ of the derived concentration guide equivalent concentrations for these radionuclides. The methods and vendor reliability are thus judged adequate to meet or test the performance objectives established for the Low-Level Burial Grounds.

\subsection{AIR QUALITY CONTROL RESULTS}

The Near-Facility Environmental Monitoring Program is subject to the analytical QA requirements specified in the Hanford Analytical Services Quality Assurance requirements document (DOE 1998). This program complies with DOE Order 414.1 and uses standards from the American Society of Mechanical Engineers (ASME NQA-1-1997 ed.) as basis. Surface Environmental Surveillance Project samples are collected by staff trained to conduct sampling according to approved and documented procedures (PNL-MA-580).

As described for the groundwater program, air filter blind spikes are submitted for analysis. However, the constituents of interest for this supplemental plan were not included. The list of analytes did include two alpha emitters (plutonium-238 and -239). During 1999, all but one of the 15 blind spikes submitted were within control limits (Poston et al. 2000). In another QC check (DOE Quality Assessment Program samples), 23 air filters, which included uranium, were analyzed (onsite laboratory). All but two of the results were within control limits. Thus, uranium, the largest contributor to potential dose for the burial grounds taken as a whole, is judged to be adequate for purposes of this plan. 
DOE/RL-2000-72, Rev. 0

$11 / 2000$

This page intentionally left blank. 


\subsection{ROLES AND RESPONSIBILITIES}

This section defines the roles of the various parties involved in collection of the air, groundwater, and subsidence data and indicates how the plan will be implemented. A tabular summary of the media to be monitored, the methods to be used, the methods of analysis, reporting, frequency of data collection, and action levels based on the data collected are also provided (Table 7.1).

\subsection{ROLES AND REPORTING}

A flow diagram summarizing the generation and reporting of performance monitoring data is shown in Figure 7.1. PNNL will collect, analyze, and report all groundwater data as well as the sitewide and offsite air monitoring data for the foreseeable future. All groundwater data for the Low-Level Burial Grounds will be summarized and formally published annually in the Hanford Site groundwater report. The data cutoff for this document is October and the document is published the following March. Also, a summary letter report of the groundwater findings relevant to the performance assessment will be transmitted to Fluor Hanford by PNNL by August 30 of each year. This report will include monitoring data collected beyond the October cutoff through the second quarter and will address the specific items of interest for the performance assessment (e.g., statistical testing results of trends, status of monitoring network).

The air monitoring used for the performance assessment maintenance report will be summarized from the ongoing Hanford Site environmental report. This information is collected on a calendar year and is generally released to the public during the summer or early fall following the end of the calendar year. This information will be reviewed and a summary letter report on the results from air monitoring findings relevant to performance assessment will be prepared by Fluor Hanford by August 30 of each year. Because the groundwater reporting cycle is on a fiscal year, there will be some data out of phase because of the different reporting periods. This is not perceived to be a major problem because it is the long-term trend that is of interest for performance assessment purposes. Subsidence monitoring information is summarized in the annual near-facility environmental monitoring report for the calendar year. Fluor Hanford will compile this information along with the groundwater and air data for the updated performance assessment maintenance report.

\subsection{IMPLEMENTATION}

Most of the required monitoring infrastructure to implement this plan is already in place as a result of the ongoing Hanford Site Environmental Monitoring Program and the Hanford Site Groundwater Monitoring Project operated by PNNL for DOE. The primary new information required involves adding the three key performance assessment constituents (iodine-129, technetium-99, and uranium) to the semiannually RCRA groundwater sampling schedule for compliance evaluation and trends analysis. After that, the routine RCRA sampling schedule (semiannually) is considered to be adequate for long-term performance assessment monitoring. When directed by DOE-RL, the additional constituents and sampling events will be scheduled by PNNL. An advance notice of one quarter is needed to initiate new sampling. 
DOE/RL-2000-72, Rev. 0

$11 / 2000$

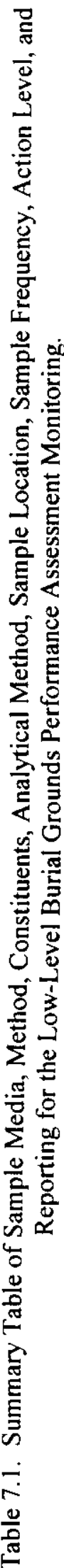

\begin{tabular}{|c|c|c|c|c|c|}
\hline & 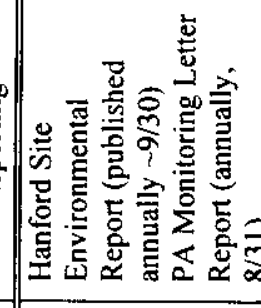 & 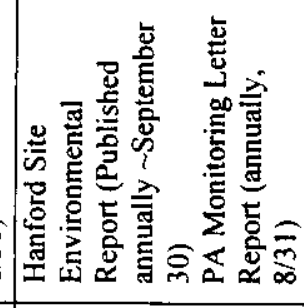 & 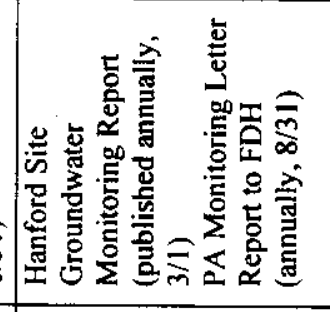 & 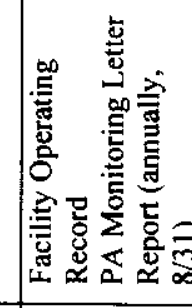 & $=$ \\
\hline & 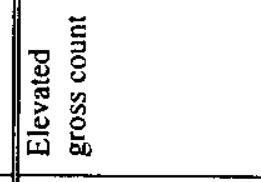 & 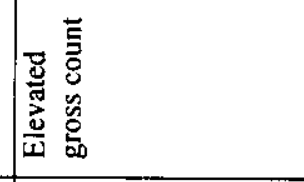 & 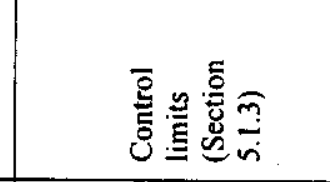 & 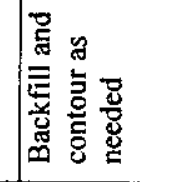 & 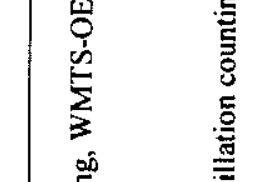 \\
\hline & 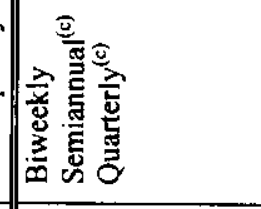 & 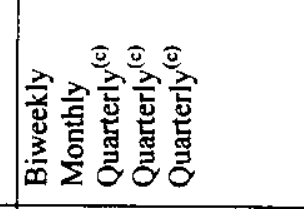 & 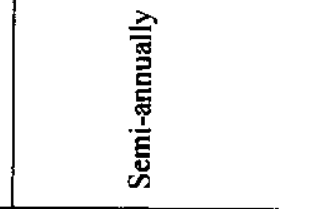 & $\frac{2}{3}$ & 竞 \\
\hline & 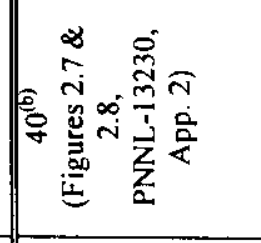 & 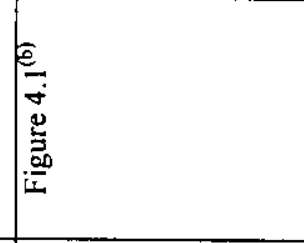 & 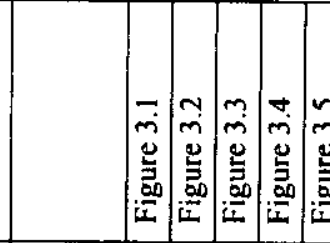 & : & 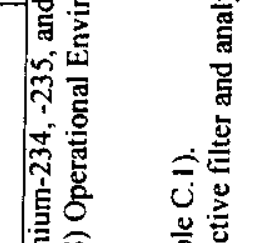 \\
\hline 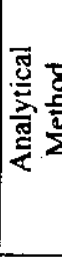 & 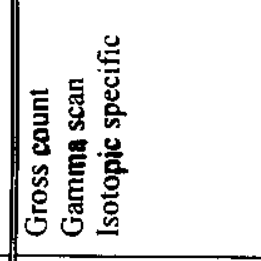 & 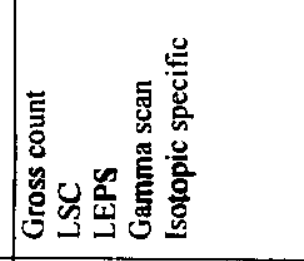 & 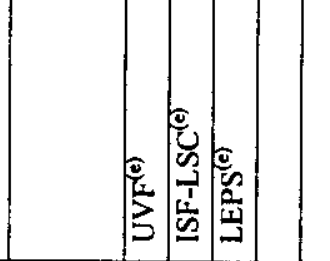 & $\underline{z}$ & 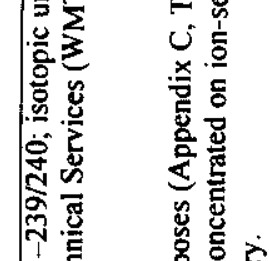 \\
\hline & 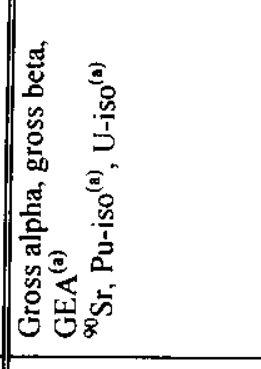 & 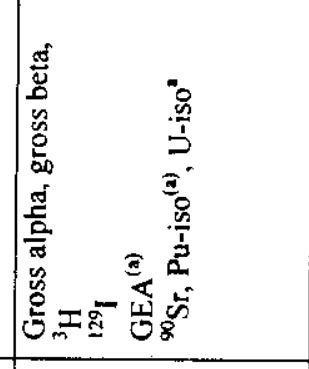 & 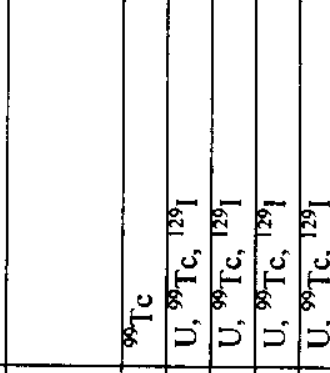 & $\mathbb{z}$ & 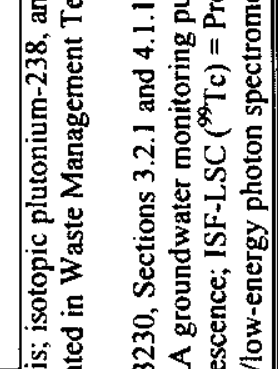 \\
\hline 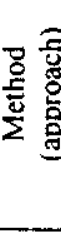 & 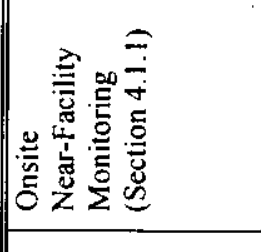 & 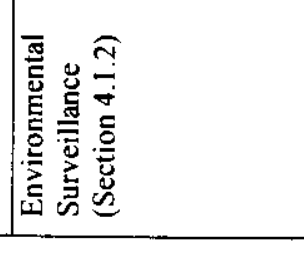 & 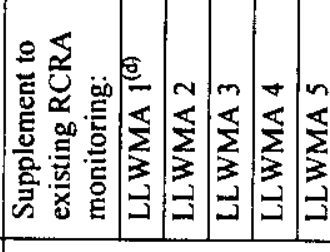 & 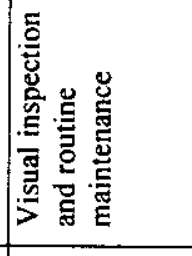 & 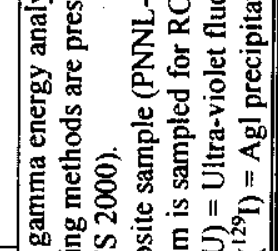 \\
\hline$\frac{\vec{v}}{2}$ & 这 & & 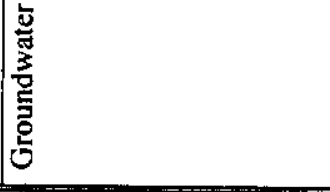 & 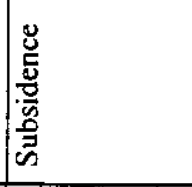 & Eิ \\
\hline
\end{tabular}




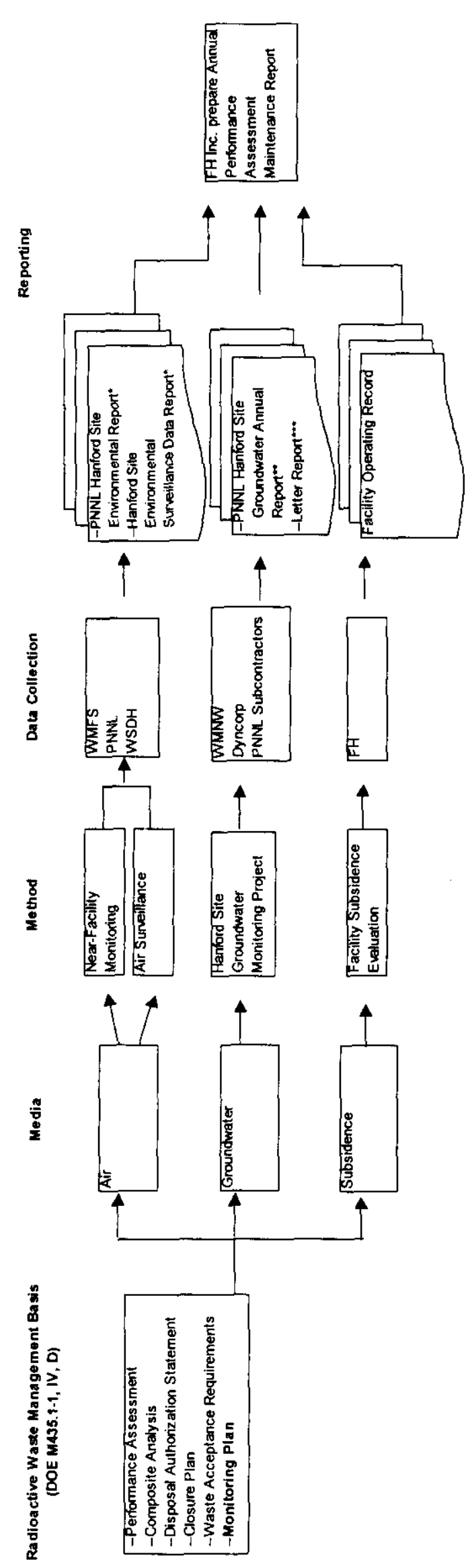

DOE/RL-2000-72, Rev. 0

$11 / 2000$

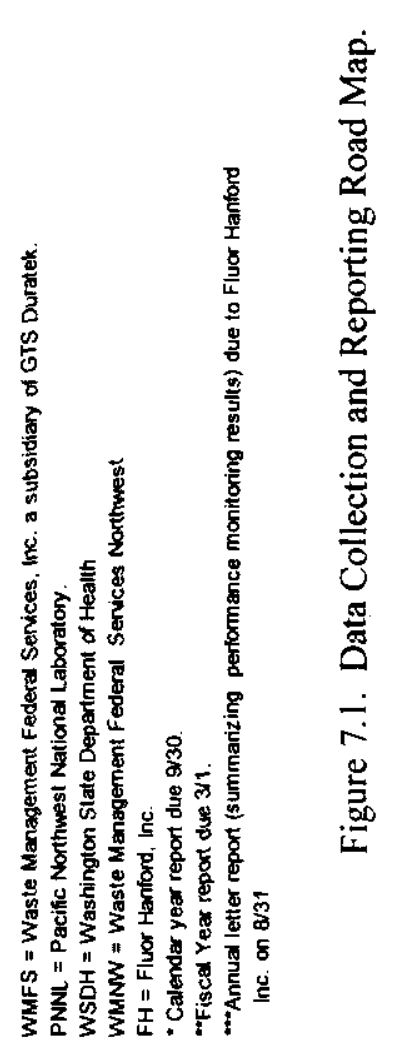


1

2

4

5

6

7 


\subsection{REFERENCES}

ASME, 1997, Quality Assurance Program for Nuclear Facilities, ASME NQA-1-1997, American Society of Mechanical Engineers, New York, New York.

ASTM, 1996, Provisional Standard Guide for Developing Appropriate Statistical Approaches for Ground-Water Detection Monitoring Programs, PS 64-96, American Society for Testing and Materials, West Conshohocken, Pennsylvania.

Bjornstad, B. N., 1984, Suprabasalt Stratigraphy Within and Adjacent to the Reference Repository Location, SD-BWI-DP-039, Rockwell Hanford Operations, Richland, Washington.

Bjornstad, B. N., 1990, Geohydrology of the 218-W-5 Burial Ground, 200-West Area, Hanford Site, PNL-7336, Pacific Northwest Laboratory, Richland, Washington.

CERCLA - Comprehensive Environmental Response, Compensation, and Liability Act of 1980, as amended, Public Law 96-510, 94 Stat. 2767, 42 USC 9601 et seq.

Conover, W. J., 1980, Practical Nonparametric Statistics, $2^{\text {nd }}$ ed., Wiley, New York, New York.

DOE Order 414.1, Quality Assurance, U.S. Department of Energy, Washington, D.C.

DOE Order 435.1, Radioactive Waste Management, U.S. Department of Energy, Washington, D.C.

DOE Order 435.1 Manual, Radioactive Waste Management Manual, U.S. Department of Energy, Washington, D.C.

DOE Order 5400.1, General Environmental Protection Program, U.S. Department of Energy, Washington, D.C.

DOE Order 5400.5, Radiation Protection of the Public and the Environment, U.S. Department of Energy, Washington, D.C.

DOE Order 5480.22, Technical Safety Requirements, U.S. Department of Energy, Washington, D.C.

DOE Order, 5480.23, Nuclear Safety Analysis Reports, U.S. Department of Energy, Washington, D.C.

DOE, 1988, Consultation Draft, Site Characterization Plan, Reference Repository Location, Hanford Site, Washington, DOE/RW-0164, Vols. 1-9, U.S. Department of Energy, Office of Civilian Radioactive Waste Management, Washington, D.C.

DOE, 1998, Hanford Analytical Service Quality Assurance Document (HA2QAO), DOE/RL-96-98, Rev. 2, U.S. Department of Energy, Richland Operations Office, Richland, Washington.

DOE, 1997, Environmental Monitoring Plan, United States Department of Energy Richland Operations Office, DOE/RL-91-50, Rev. 2, U.S. Department of Energy, Richland Operations Office, Richland, Washington.

DOE, 1999, Hanford Comprehensive Land-Use Plan Record of Decision Environmental Impact Statement, U.S. Department of Energy, Richland Operations Office, Richland, Washington. 
DOE, 2000, Low-Level Burial Grounds Closure Plan, DOE/RL-2000-70, U.S. Department of Energy, Richland Operations Office, Richland, Washington.

Ecology, 1996, Implementation Guidance for the Ground Water Quality Standards, Publication \#96-02, Washington State Department of Ecology Water Quality Program, Olympia, Washington.

Ecology - Washington State Department of Ecology, U.S. Environmental Protection Agency, and U.S. Department of Energy. 1998. Hanford Federal Facility Agreement and Consent Order. Document No. 89-10, Rev. 5 (The Tri-Party Agreement), Olympia, Washington.

EPA, 1989, Statistical Analysis of Ground-Water Monitoring Data at RCRA Facilities-Interim Final Guidance, PB89-151047, U.S. Environmental Protection Agency, Washington, D.C.

EPA, 1992, Statistical Analysis of Ground-Water Monitoring Data at RCRA Facilities: Addendum to Interim Final Guidance, U.S. Environmental Protection Agency, Washington, D.C.

Fayer, M. J., M. L. Rockford, and G. W. Gee, 1991, Recharge Potential of a Sandy Soil, EOS (Transactions of the American Geophysical Union), Vol. 72, page 1074.

Gee, G. W., 1987, Recharge at the Hanford Site: Status Report, PNL-6403, Pacific Northwest Laboratory, Richland, Washington.

Gibbons, R. D., 1994, Statistical Methods for Groundwater Monitoring, John Wiley \& Sons, New York, New York.

Goodwin, S. M., and B. N. Bjornstad, 1990, 200-East and 200-West Areas Low-Level Burial Grounds Borehole Summary Report, WHC-MR-0204, Westinghouse Hanford Company, Richland, Washington.

Graharı, M. J., G. V. Last, and K. R. Fecht, 1984, An Assessment of Aquifer Intercommunication in the $B$ Pond-Gable Mountain Pond Area of the Hanford Site, RHO-RE-ST-12 P, Rockwell Hanford Operations, Richland Washington.

Hahn, G. J., and W. Q. Meeker, 1991, Statistical Intervals, A Guide for Practitioners, John Wiley and Sons, Inc., New York, New York.

Hartman, M. J., L. F. Morasch, and W. D. Webber (eds.), 2000, Hanford Site Groundwater Monitoring for Fiscal Year 1999, PNNL-13116, Pacific Northwest National Laboratory, Richland, Washington.

HNF-EP-0528-3, 1997, NESHAP Quality Assurance Project Plan for Radioactivity Air Emissions, Fluor Hanford, Inc. for U.S. Department of Energy, Richland, Washington.

HNF-SD-WM-ISB-002, 1994, Solid Waste Burial Grounds Interim Safety Basis, Westinghouse Hanford Company, Richland, Washington.

Hoitink, D. J., K. W. Burk, and J. V. Ramsdell, 2000, Hanford Site Climatological Data Summary 1999 With Historical Data, PNNL-13117, Pacific Northwest National Laboratory, Richland, Washington.

Kincaid, C. T., M. P. Bergeron, C. R. Cole, M. D. Freshley, N. L. Hassig, V. G. Johnson, D. I. Kaplan, R. J. Serne, G. P. Streile, D. L. Strenge, P. D. Thorne, L. W. Vail, G. A. Whyatt, and 
S. K. Wurstner, 1998, Composite Analysis for Low-Level Waste Disposal in the 200 Area Plateau of the Hanford Site, PNNL-1 1800, Pacific Northwest National Laboratory, Richland, Washington.

Last, G. V., B. N. Bjornstad, M. P. Bergeron, D. W. Wallace, D. R. Newcomer, J. A. Schramke, M. A. Chamness, C. S. Cline, S. P. Airhart, and J. S. Wilbur, 1989, Hydrogeology of the 200 Areas Low-Level Burial Grounds- An Interim Report, PNL-6820, Pacific Northwest Laboratory, Richland, Washington.

Lindsey, K. A., J. L. Slate, G. K. Jaeger, K. J. Swett, and R. B. Mercer, 1994, Geologic Setting of the Low-Level Burial Grounds, WHC-SD-EN-TI-290, Rev. 0, Westinghouse Hanford Company, Richland, Washington.

Lucas, James M., 1982, "Combined Shewhart-CUSUM Quality Control Schemes.” Journal of Quality Technology, Vol. 14, No. 2, 51-59.

Mandansky, A., 1988, Prescriptions for Working Statisticians, Springer-Verlag, New York, New York.

Maxfield, H. L., 1979, Handbook - 200 Area Waste Sites, RHO-CD-673, Vols. 1 and 2, Rockwell Hanford Operations, Richland, Washington.

Mercer, R. B., 1993a, 1991 Borehole Completion Data Package for the Low-Level Burial Grounds, WHC-SD-EN-DP-044, Rev. 0, Westinghouse Hanford Company, Richland, Washington.

Mercer, R. B., 1993b, 1992 Borehole Completion Data Package for the Low-Level Burial Grounds, WHC-SD-EN-DP-049, Rev. 0, Westinghouse Hanford Company, Richland, Washington.

Mercer, R. B., 1994, 1993 Borehole Completion Data Package for the Low-Level Burial Grounds, WHC-SD-EN-DP-086, Rev. 0, Westinghouse Hanford Company, Richland, Washington.

Miller, J. C., and J. N. Miller, 1988, Statistics for Analytical Chemistry, Second Edition, Ellis Horwood Limited, Chichester, England.

Miller, R. G., Jr., 1986, Beyond ANOVA, Basics of Applied Statistics, John Wiley \& Sons, New York. New York.

Perkins, C. J., B. M. Markes, S. M. McKinney, R. M. Mitchell, and R. C. Roos, 2000, Hanford Site Near-Facility Environmental Monitoring Data Report for Calendar Year 1999, PNNL-13230, APP. 2, Waste Management Federal Services, Inc., a Subsidiary of GTS Duratek, Richland, Washington.

Poston, T. M., R. W. Hanf, and R. L. Dirkes (eds.), 2000, Hanford Site Environmental Report for Calendar Year 1999, PNNL-13230, Pacific Northwest National Laboratory, Richland, Washington.

PNL-MA-580, 1996, Surface Environmental Surveillance Procedures Manual, Rev. 2, Pacific Northwest National Laboratory, Richland, Washington.

RCRA - Resource Conservation and Recovery Act (1976), Public Law 94-580, as amended, 90 Stat. 2795, 42 USC 6901 et seq.

Routson, R. C., and V. G. Johnson, 1990, Recharge Estimates for the Hanford Site Separations Area, December 1987, WHC-EP-0142, Westinghouse Hanford Company, Richland, Washington. 
Rockhold, M. L., M. J. Fayer, G. W. Gee, and M. J. Kanyid, 1990, Natural Groundwater Recharge and Water Balance at the Hanford Site, PNL-7215, Pacific Northwest Laboratory, Richland, Washington.

Shapiro, S. S., and M. B. Wilk, 1965, "An Analysis of Variance Test for Normality (Complete Sample)." Biometrika 52:591-611.

Starks, Thomas H., 1988, Evaluation of Control Chart Methodologies for RCRA Waste Sites, U.S. EPA Technical Report CR814342-01-3, U.S. Environmental Protection Agency Office of Research and Development, Las Vegas, Nevada.

Starks, Thomas H., 1989, Evaluation of Control Chart Methodologies for RCRA Waste Sites, EPA/600/4-88/040, U.S. Environmental Protection Agency Office of Research and Development, Las Vegas, Nevada.

Tallman, A. M., K. R. Fecht, M. J. Marratt, and G. V. Last, 1979, Geology of the Separation Areas Hanford Site, South Central Washington, RHO-ST-23, Rockwell Hanford Operations, Richland, Washington.

WAC 173-303, Washington State Dangerous Waste Regulations, Department of Ecology, Olympia, Washington.

Williams, B. A., B. N. Bjornstad, R. Schalla, and W. D. Webber, 2000, Revised Hydrogeology for the Suprabasalt Aquifer System, 200-East Area and Vicinity, Hanford Site, Washington. PNNL-12261, Pacific Northwest National Laboratory, Richland, Washington.

Wood, M. I., 1996, Addendum to the Performance Assessment Analysis for Low-Level Waste Disposal in the 200 West Area Burial Grounds, HNF-SD-WM-TI-798, Rev. 0, Rust Federal Services of Hanford, Inc. for U.S. Department of Energy, Richland, Washington.

Wood, M. 1., 1998, Addendum to the Performance Assessment Analysis for Low-Level Waste Disposal in the 200 East Area Burial Grounds, HNF-2005, Rev. 0, Rust Federal Services of Hanford, Inc. for U.S. Department of Energy, Richland, Washington.

Wood, M. I., R. Khaleel, P. D. Rittman, A. H. Lu, S. H. Finfrock, R. J. Serne, K. J. Cantrell, and T. H. DeLorenzo, 1995, Performance Assessment for the Disposal of Low-Level Waste in the 200 West Area Burial Grounds, WHC-EP-0645, Westinghouse Hanford Company, Richland, Washington.

Wood, M. I., R. Khaleel, P. D. Rittman, A. H. Lu, S. H. Finfrock, R. J. Serne, K. J. Cantrell, and T. H. Delorenzo, 1995, Performance Assessment for the Disposal of Low-Level Waste in the 200 East Area Burial Grounds. WHC-EP-0645, Westinghouse Hanford Company, Richland, Washington. 


\section{Appendix A}

\section{Relative Hazard Index Values and List of Constituents for the} 200 Areas Low-Level Burial Grounds 
DOE/RL-2000-72, Rev. 0

$11 / 2000$

This page intentionally left blank. 


\section{Appendix A}

\section{Relative Hazard Index Values and List of Constituents for the 200 Areas Low-Level Burial Grounds}

This appendix documents computation of the relative hazard index for each mobile constituent identified in the performance assessment (Wood et al. 1995; Wood 1996 and 1998) and the composite analysis (Kincaid et al. 1998). The percent contribution of each constituent for the 200 East Area and 200 West Area burial grounds are shown at the bottom of Tables A.la and A.1b, respectively. The inventories from the Low-Level Burial Ground closure plan were used to include the pre-1988 estimated inventories that were not included in the performance assessments. The intent was to make the inventories match current conditions as closely as possible for a more meaningful comparison of operational monitoring results with performance objectives.

\section{A.1 References}

DOE Order 5400.5, Radiation Protection of the Public and the Environment. U.S. Department of Energy, Washington, D.C.

DOE. 2000. Low-Level Burial Grounds Closure Plan. DOE/RL-2000-70, U.S. Department of Energy, Richland Operations Office, Richland, Washington.

Kincaid, C. T., M. P. Bergeron, C. R. Cole, M. D. Freshley, N. L. Hassig, V. G. Johnson, D. I. Kaplan, R. J. Serne, G. P. Streile, D. L. Strenge, P. D. Thorne, L. W. Vail, G. A. Whyatt, and S. K. Wurstner. 1998. Composite Analysis for Low-Level Waste Disposal in the 200 Area Plateau of the Hanford Site. PNNL-11800, Pacific Northwest National Laboratory, Richland, Washington.

Wood, M. I. 1996. Addendum to the Performance Assessment Analysis for Low-Level Waste Disposal in the 200 West Area Burial Grounds. HNF-SD-WM-TI-798, Rev. 0, Rust Federal Services of Hanford, Inc. for U.S. Department of Energy, Richland, Washington.

Wood, M. I. 1998. Addendum to the Performance Assessment Analysis for Low-Level Waste Disposal in the 200 East Area Burial Grounds, HNF-2005, Rev. 0, Rust Federal Services of Hanford, Inc. for U.S. Department of Energy, Richland, Washington.

Wood, M. I., R. Khaleel, P. D. Rittman, A. H. Lu, S. H. Finfrock, R. J. Serne, K. J. Cantrell, and T. H. DeLorenzo. 1995. Performance Assessment for the Disposal of Low-Level Waste in the 200 West Area Burial Grounds. WHC-EP-0645, Westinghouse Hanford Company, Richland, Washington. 
Table A.1a. Relative Hazard Index for the 200 East Area Burial Grounds (Groundwater Ingestion Exposure Route, Radionuclides)

\begin{tabular}{|c|c|c|c|c|c|c|c|c|}
\hline \multirow[b]{2}{*}{ Burial Ground } & \multirow[b]{2}{*}{ LLWMA } & \multicolumn{7}{|c|}{ Radionuclide Inventories } \\
\hline & & ${ }^{14} \mathrm{C}$ & ${ }^{36} \mathrm{Cl}$ & ${ }^{129} \mathrm{I}$ & ${ }^{79} \mathrm{Se}$ & ${ }^{99} \mathrm{Tc}$ & ${ }^{2318} \mathrm{U}$ & Total \\
\hline 218-E-10 & 1 & -- & $\cdots$ & -- & 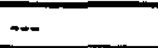 & $5.07 \mathrm{E}-03^{(a)}$ & $1.14 \mathrm{E}-02^{(\mathrm{a})}$ & \\
\hline $218-E-12 B$ & 2 & $1.31 \mathrm{E}+02^{(\mathrm{a})}$ & $5.56 \mathrm{E}-03^{(\mathrm{d})}$ & $2.94 \mathrm{E}-03^{(\mathrm{a})}$ & $2.31 \mathrm{E}-05^{(a)}$ & $8.08 \mathrm{E}-01^{(n)}$ & $4.68 \mathrm{E}-03^{(2)}$ & \\
\hline \multicolumn{9}{|c|}{ Derived Concentration Guide ${ }^{(b)}$} \\
\hline Guidance Value & & 70,000 & 50,000 & 500 & 20,000 & 100,000 & 600 & \\
\hline \multicolumn{9}{|c|}{ Relative Hazard Index ${ }^{(c)}$} \\
\hline $218-E-10$ & 1 & $-\cdots$ & -- & $-\cdots$ & --- & $7.24 \mathrm{E}-08$ & $1.63 \mathrm{E}-07$ & $2.35 \mathrm{E}-07$ \\
\hline $218-\mathrm{E}-12 \mathrm{~B}$ & 2 & $1.87 \mathrm{E}-03$ & $1.11 \mathrm{E}-07$ & $5.88 \mathrm{E}-06$ & $1.16 \mathrm{E}-09$ & 8.08E-06 & $7.80 \mathrm{E}-06$ & $1.89 \mathrm{E}-03$ \\
\hline \multicolumn{9}{|c|}{$\%$ of Total ${ }^{(\mathrm{d})}$} \\
\hline $218-E-10(\%)$ & 1 & -- & --- & $\cdots$ & -- & 30.8 & 69.2 & 100 \\
\hline $218-\mathrm{E}-12 \mathrm{~B}(\%)$ & 2 & 98.9 & 0.0 & 0.3 & 0.0 & 0.4 & 0.4 & 100 \\
\hline \multicolumn{9}{|c|}{$\begin{array}{l}\text { Source: from Table } 2.3 \text { (DOE } 2000 \text { ), in curies. } \\
\text { (b) Derived concentration guide (DCG) values (in pCi/L) are from DOE Order } 5400.5 \text {. } \\
\text { (c) Relative hazard index (RHI) is computed by dividing the source concentration by the appropriate DCG. } \\
\text { (d) Percent (\%) of total is obtained by dividing individual RHI values by the sum of all RHI values in the } \\
\text { constituent group. }\end{array}$} \\
\hline
\end{tabular}


Table A.1b. Relative Hazard Index for the 200 West Area Burial Grounds (Groundwater Ingestion Exposure Route, Radionuclides)

\begin{tabular}{|c|c|c|c|c|c|c|c|c|}
\hline \multirow[b]{2}{*}{ Burial Ground } & \multirow[b]{2}{*}{ LLWMA } & \multicolumn{7}{|c|}{ Radionuclide Inventories ${ }^{(a)}$} \\
\hline & & ${ }^{14} \mathrm{C}$ & ${ }^{36} \mathrm{Cl}$ & ${ }^{129} \mathrm{~J}$ & ${ }^{79} \mathrm{Se}$ & ${ }^{99} \mathrm{Tc}$ & ${ }^{238} \mathrm{U}$ & Total \\
\hline $218-W-3 A$ & 3 & $1.74 \mathrm{E}+00^{(\mathrm{a})}$ & $2.00 \mathrm{E}-04^{(\mathrm{a})}$ & $1.44 \mathrm{E}-02^{(\mathrm{a})}$ & $1.12 \mathrm{E}-04^{(\mathrm{a})}$ & $2.88 \mathrm{E}-01^{(a)}$ & $1.11 \mathrm{E}-01^{(2)}$ & \\
\hline $218-\mathrm{W}-3 \mathrm{AE}$ & 3 & $1.39 \mathrm{E}+01^{(\mathrm{a})}$ & $1.35 \mathrm{E}-03^{(\mathrm{a})}$ & $4.01 \mathrm{E}-04^{(\mathrm{a})}$ & $9.77 \mathrm{E}-03^{(\mathrm{a})}$ & $9.80 \mathrm{E}+00^{(a)}$ & $6.22 \mathrm{E}+01^{(n)}$ & \\
\hline $218-W-5$ & 3 & $5.28 \mathrm{E}+00^{(\mathrm{a})}$ & $2.04 \mathrm{E}-03^{(\mathrm{a})}$ & $3.44 \mathrm{E}-02^{(a)}$ & $5.00 \mathrm{E}-03^{(\mathrm{s})}$ & $3.95 \mathrm{E}-01^{(0)}$ & $6.66 \mathrm{E}-01^{(2)}$ & \\
\hline $218 \cdot W-4 B$ & 4 & $\cdots$ & $\cdots$ & $5.00 \mathrm{E}-01^{(\mathrm{a})}$ & -- & $\cdots$ & -- & \\
\hline $218-W-4 C$ & 4 & $2.63 \mathrm{E}+00^{(2)}$ & $1.61 \mathrm{E}-05^{(\mathrm{a})}$ & $1.46 \mathrm{E}-03^{(\mathrm{n})}$ & $2.71 \mathrm{E}-05^{(\mathrm{a})}$ & $1.64 \mathrm{E}+01^{\mathrm{a}}$ & $4.01 \mathrm{E}+01^{(\mathrm{B})}$ & \\
\hline \multicolumn{9}{|c|}{ Derived Concentration Guide ${ }^{(\mathrm{b})}$} \\
\hline Guidance value & & 70,000 & 50,000 & 500 & 20,000 & 100,000 & 600 & \\
\hline \multicolumn{9}{|c|}{ Relative Hazard Index } \\
\hline $218-W-3 A$ & 3 & $2.49 \mathrm{E}-05$ & $4.00 \mathrm{E}-09$ & $2.88 \mathrm{E}-05$ & $5.60 \mathrm{E}-09$ & $2.88 \mathrm{E}-06$ & $1.85 \mathrm{E}-04$ & $2.42 \mathrm{E}-04$ \\
\hline $218-W-3 A E$ & 3 & $1.99 \mathrm{E}-04$ & $2.70 \mathrm{E}-08$ & $8.02 \mathrm{E}-07$ & $4.89 \mathrm{E}-07$ & $9.80 \mathrm{E}-05$ & $1.04 \mathrm{E}-01$ & $1.04 \mathrm{E}-01$ \\
\hline $218-W-5$ & 3 & $7.54 \mathrm{E}-05$ & $4.08 \mathrm{E}-08$ & $6.88 \mathrm{E}-05$ & $2.50 \mathrm{E}-07$ & $3.95 \mathrm{E}-06$ & $1.11 \mathrm{E}-03$ & $1.26 \mathrm{E}-03$ \\
\hline 218-W-4B & 4 & $0.00 \mathrm{E}+00$ & $0.00 \mathrm{E}+00$ & $1.00 \mathrm{E}-03$ & $0.00 \mathrm{E}+00$ & $0.00 \mathrm{E}+00$ & $0.00 \mathrm{E}+00$ & $1.00 \mathrm{E}-03$ \\
\hline $218-W-4 C$ & 4 & $3.76 \mathrm{E}-05$ & $3.22 \mathrm{E}-10$ & $2.92 \mathrm{E}-06$ & $1.36 \mathrm{E}-09$ & $1.64 \mathrm{E}-04$ & $6.68 \mathrm{E}-02$ & $6.70 \mathrm{E}-02$ \\
\hline \multicolumn{9}{|c|}{$\%$ of Total ${ }^{(d)}$} \\
\hline $218-W-3 A(\%)$ & 3 & 10.3 & 0.0 & 11.9 & 0.0 & 1.2 & 76.6 & 100 \\
\hline $218-\mathrm{W}-3 \mathrm{AE}(\%)$ & 3 & 0.2 & 0.0 & 0.0 & 0.0 & $0 . \overline{1}$ & 99.7 & 100 \\
\hline $218-W-5(\%)$ & 3 & 6.0 & 0.0 & 5.5 & 0.0 & 0.3 & 88.2 & 100 \\
\hline 218-W-4B (\%) & 4 & 0.0 & 0.0 & 100.0 & 0.0 & 0.0 & 0.0 & 100 \\
\hline $218-\mathrm{W}-4 \mathrm{C}(\%)$ & 4 & 0.1 & 0.0 & 0.0 & 0.0 & 0.2 & 99.7 & 100 \\
\hline \multicolumn{9}{|c|}{$\begin{array}{l}\text { Source: from Table } 2.3 \text { (DOE 2000), in curies. } \\
\text { (b) The derived concentration guide (DCG) values (in } \mathrm{pCi} / \mathrm{L} \text { ) are from DOE Order } 5400.5 \text {. } \\
\text { (c) Relative hazard index (RHI) is computed by dividing the source concentration by the appropriate DCG. } \\
\text { (d) Percent (\%) of total is obtained by dividing individual RHI values by the sum of all RHI values in the constituent group. }\end{array}$} \\
\hline
\end{tabular}

Although carbon-14 was a significant percentage of the inventory in two burial ground waste management areas, carbon-14 was excluded as a likely groundwater pathway contributor in Low-Level Waste Management Area 2 because (1) carbon- 14 is contained in decommissioned U.S. Navy defueled reactor compartments that are self-contained and the source is irradiated carbon steel and (2) in Low-Level Waste Management Area 3, carbon-14 is contained in concrete and not likely to leach. Also, the high carbonate content of the vadose zone should act as a sink or would at least significantly retard any carbon-14 that did leach from the burial ground. 
DOE/RL-2000-72, Rev. 0

$11 / 2000$

This page intentionally left blank. 


\section{Appendix B}

\section{Locations of Individual Trenches and Types of Wastes} Contained in Each Burial Ground 
DOE/RL-2000-72, Rev. 0

$11 / 2000$

This page intentionally left blank. 
This appendix contains maps showing locations of specific trenches within each of the active Low-Level Burial Grounds. Also shown are the dates when a trench was last filled. The different types of waste in each trench are color-coded as follows:

- Yellow designates radioactive waste

- Green indicates mixed wastes

- Red indicates retrievably stored transuranic waste

- Magenta or maroon indicates unused portions of a trench

- Brown indicates an unused portion of each burial ground.

There are eight burial grounds shown in Figures B.1 through B.8. These correspond to five waste management areas for RCRA monitoring purposes (Chapter 2.0 provides explanation). 
DOE/RL-2000-72, Rev. 0

$11 / 2000$

This page intentionally left blank. 
DOE/RL-2000-72, Rev. 0

$11 / 2000$

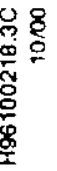

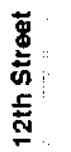

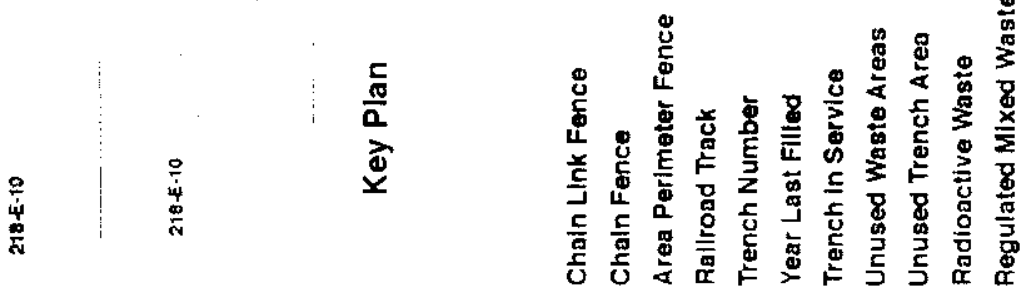

aAv UOJYY

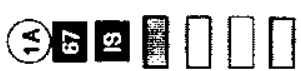

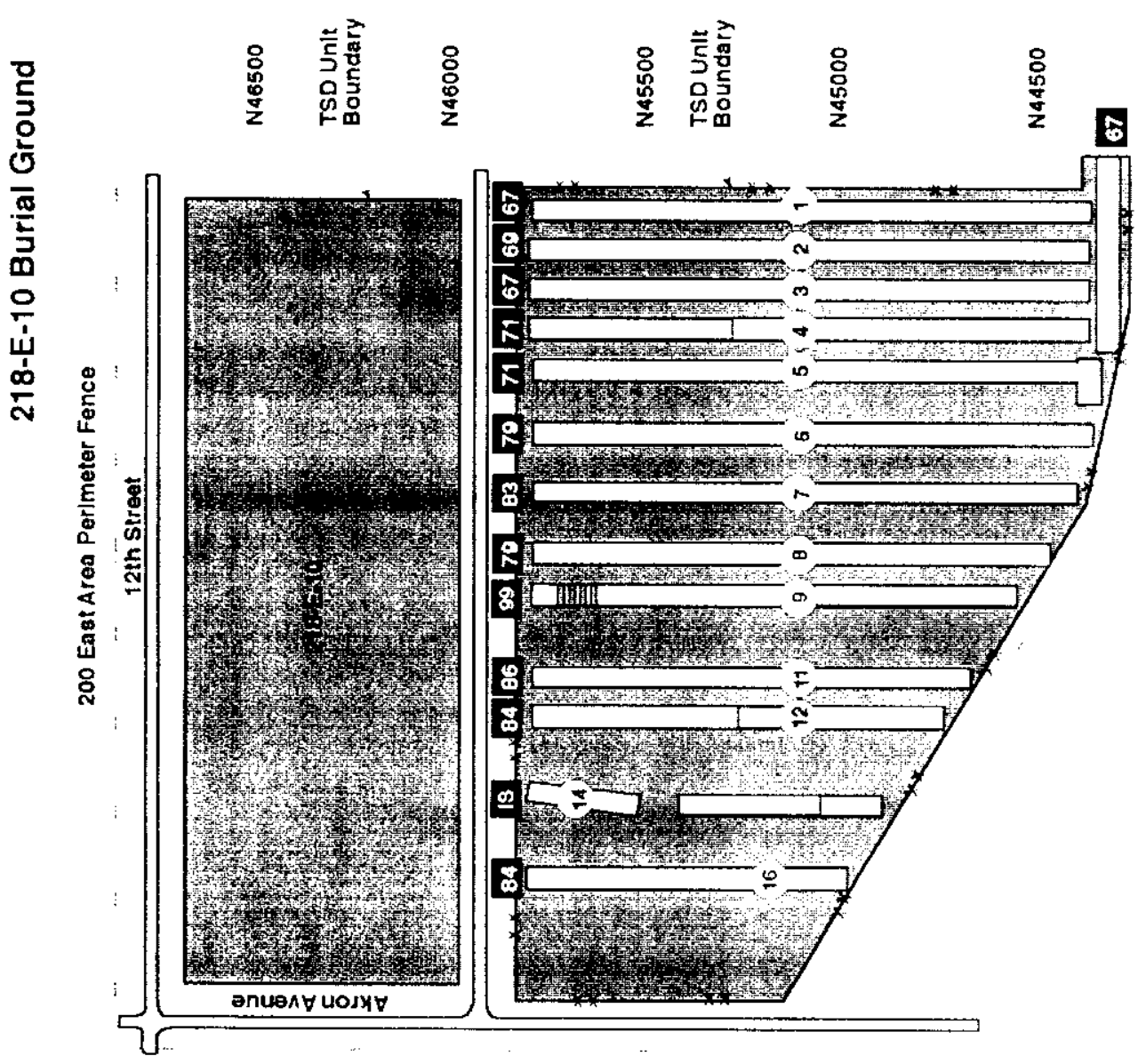

|

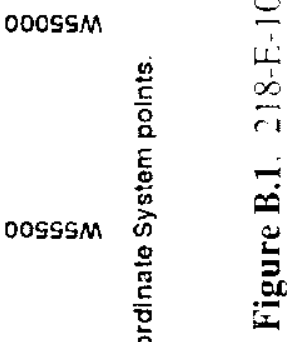


DOE/RL $-2000-72$, Rev. 0

$11 / 2000$

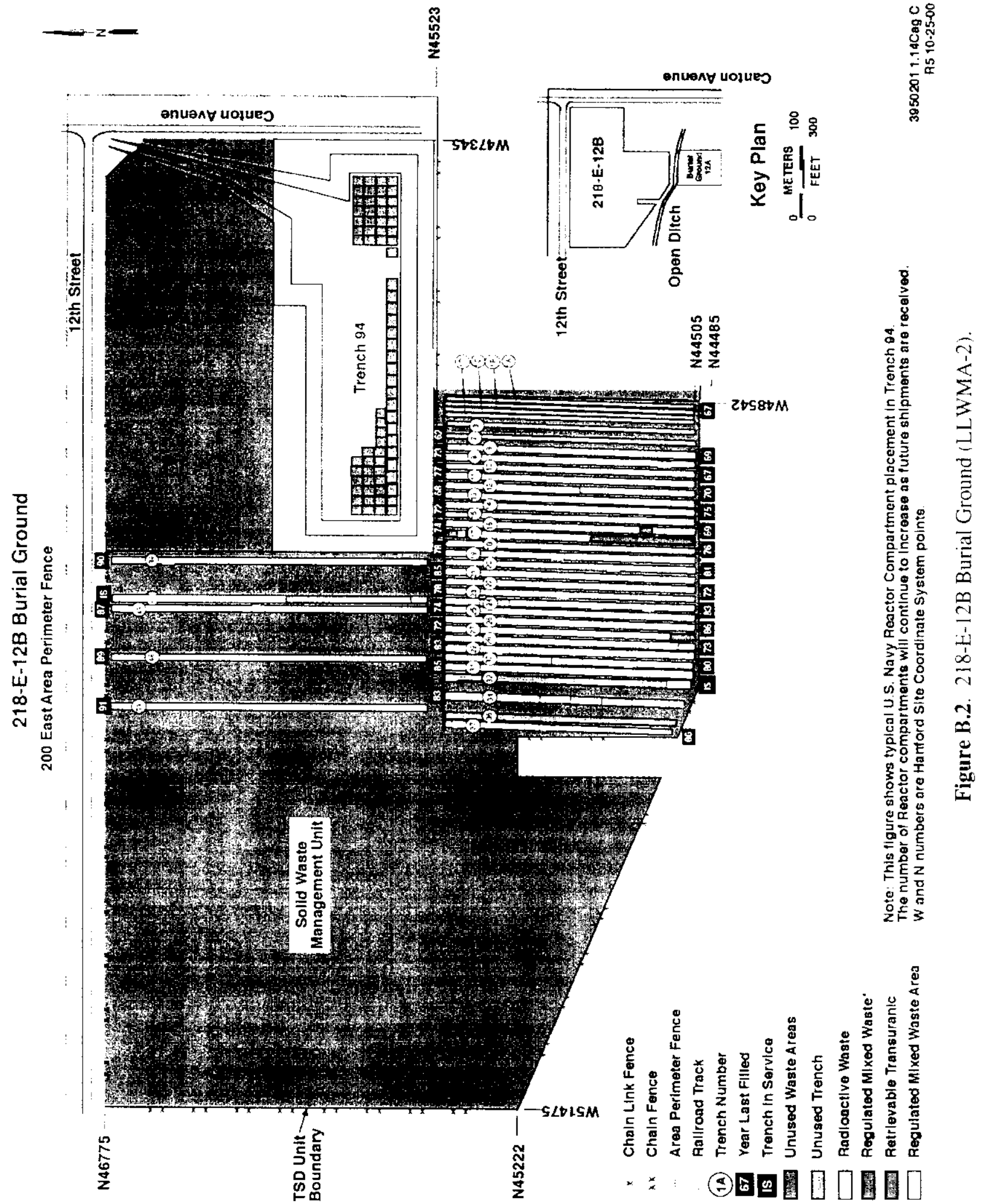




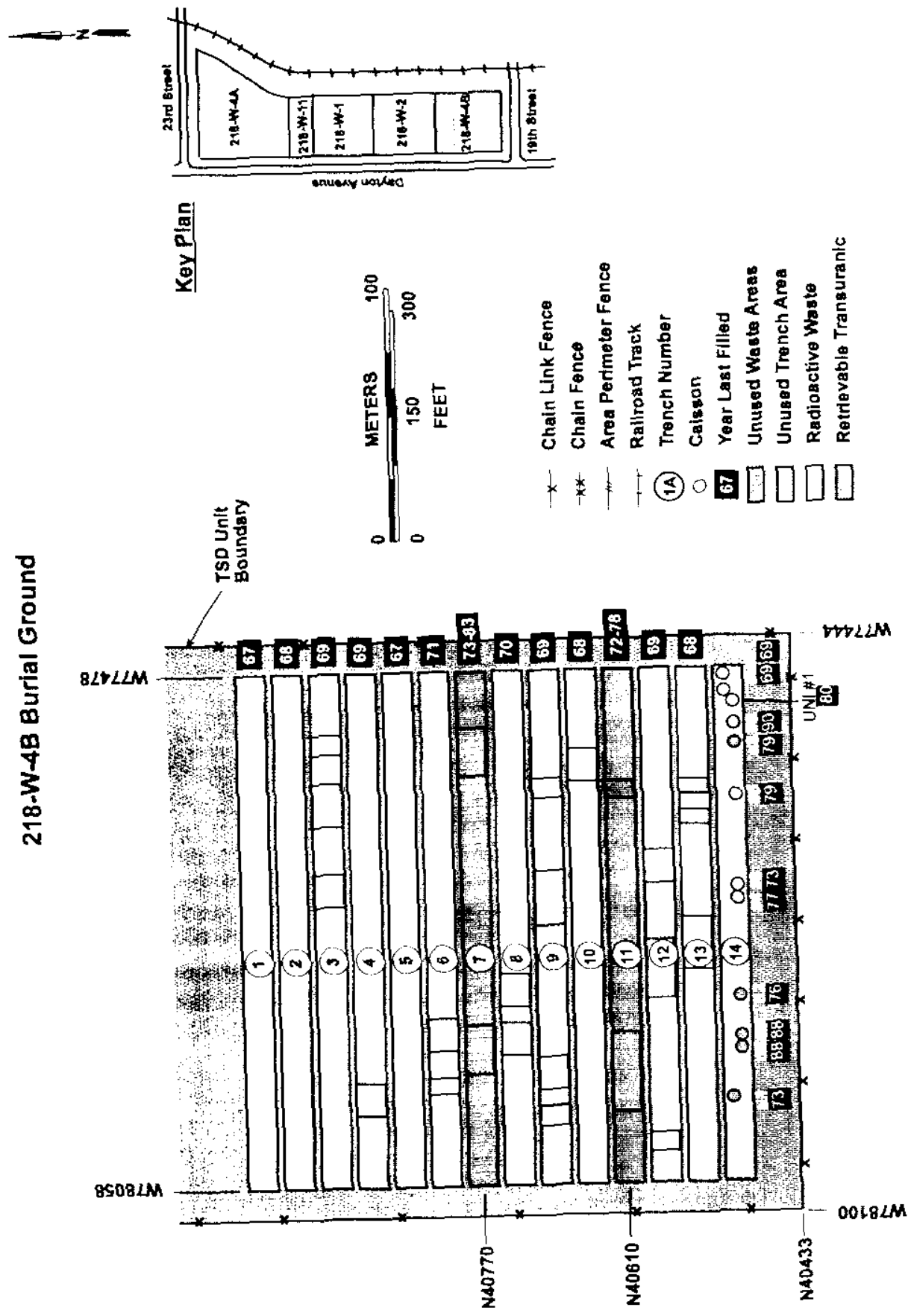

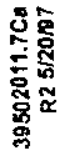

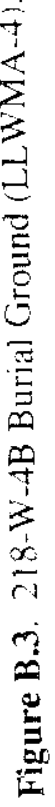




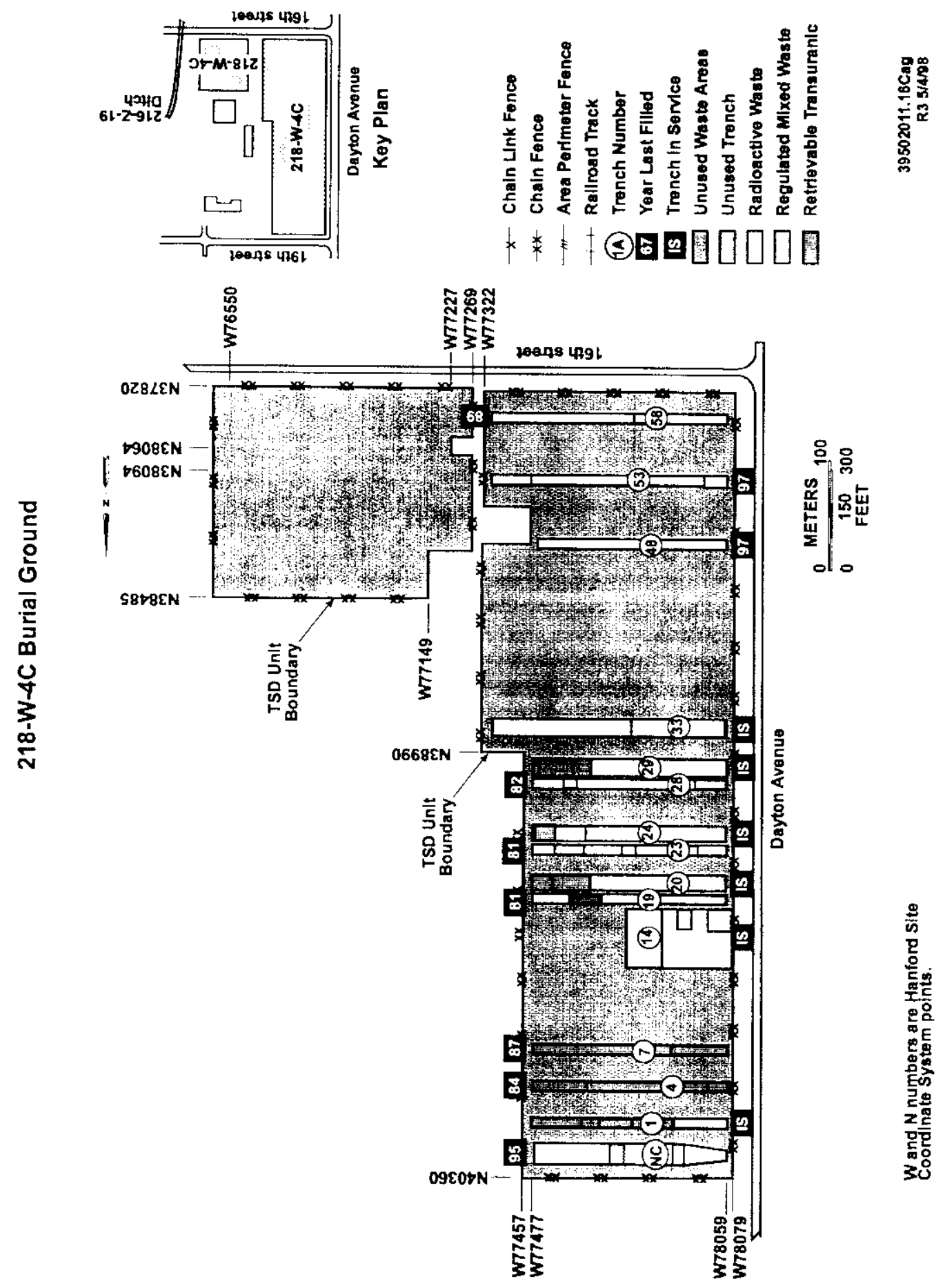




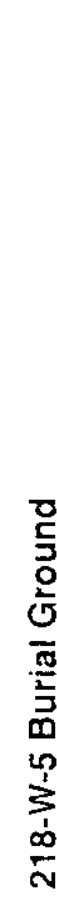

\200 West A rea Perimeter Fence

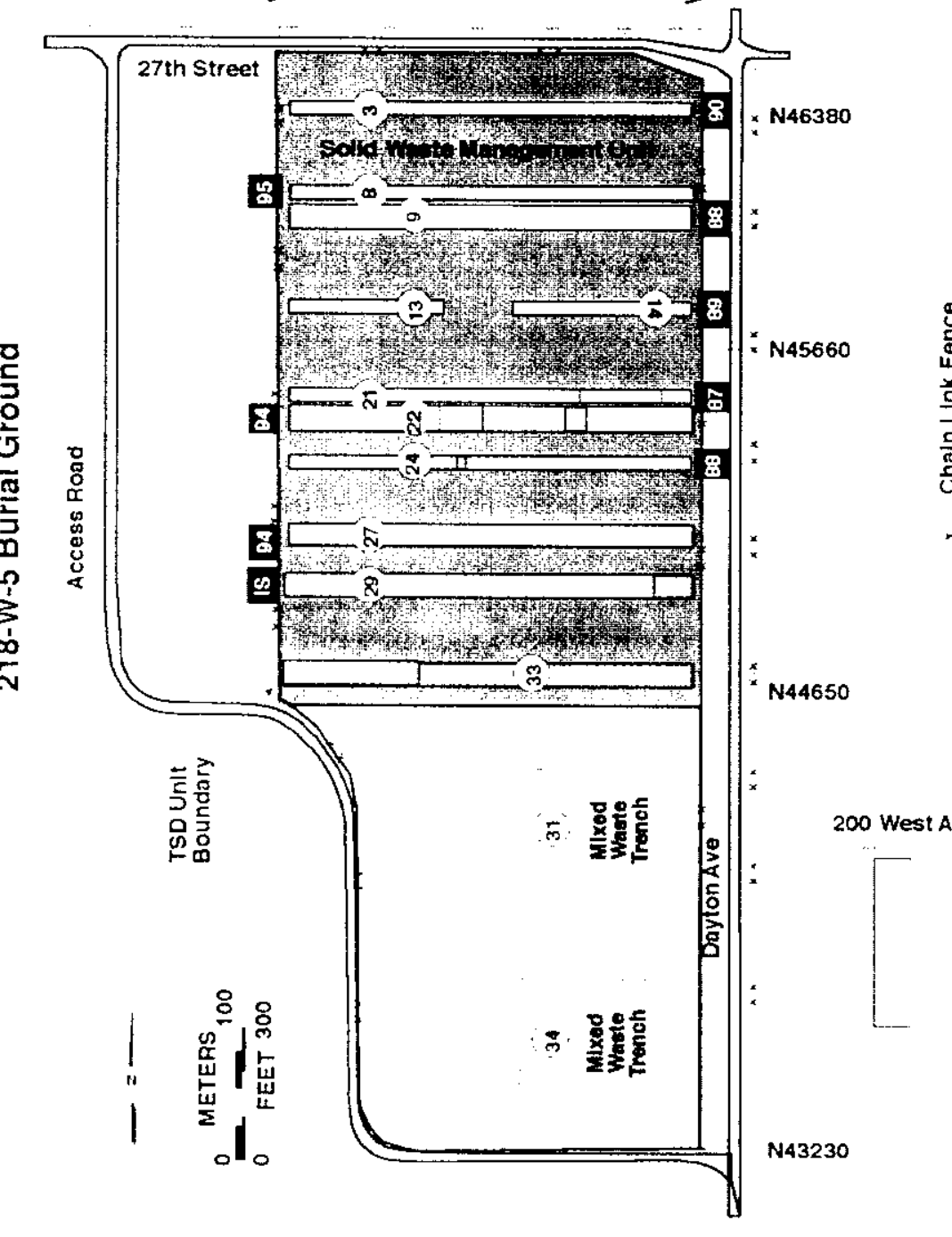

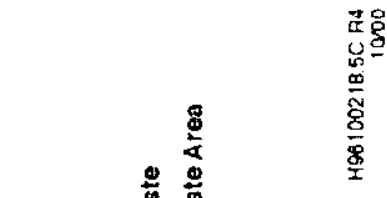

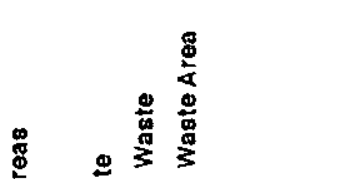

$\frac{\frac{5}{0}}{\frac{\pi}{\alpha}}$

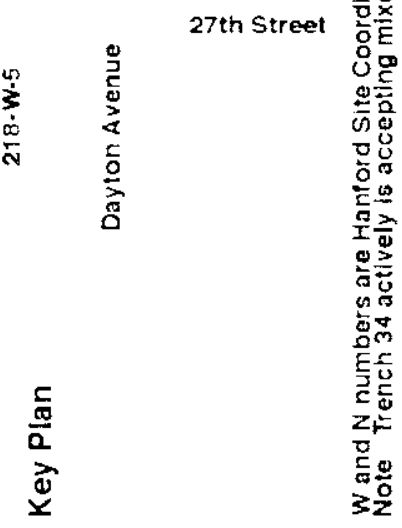


DOE/RL-2000-72, Rev. 0

$11 / 2000$

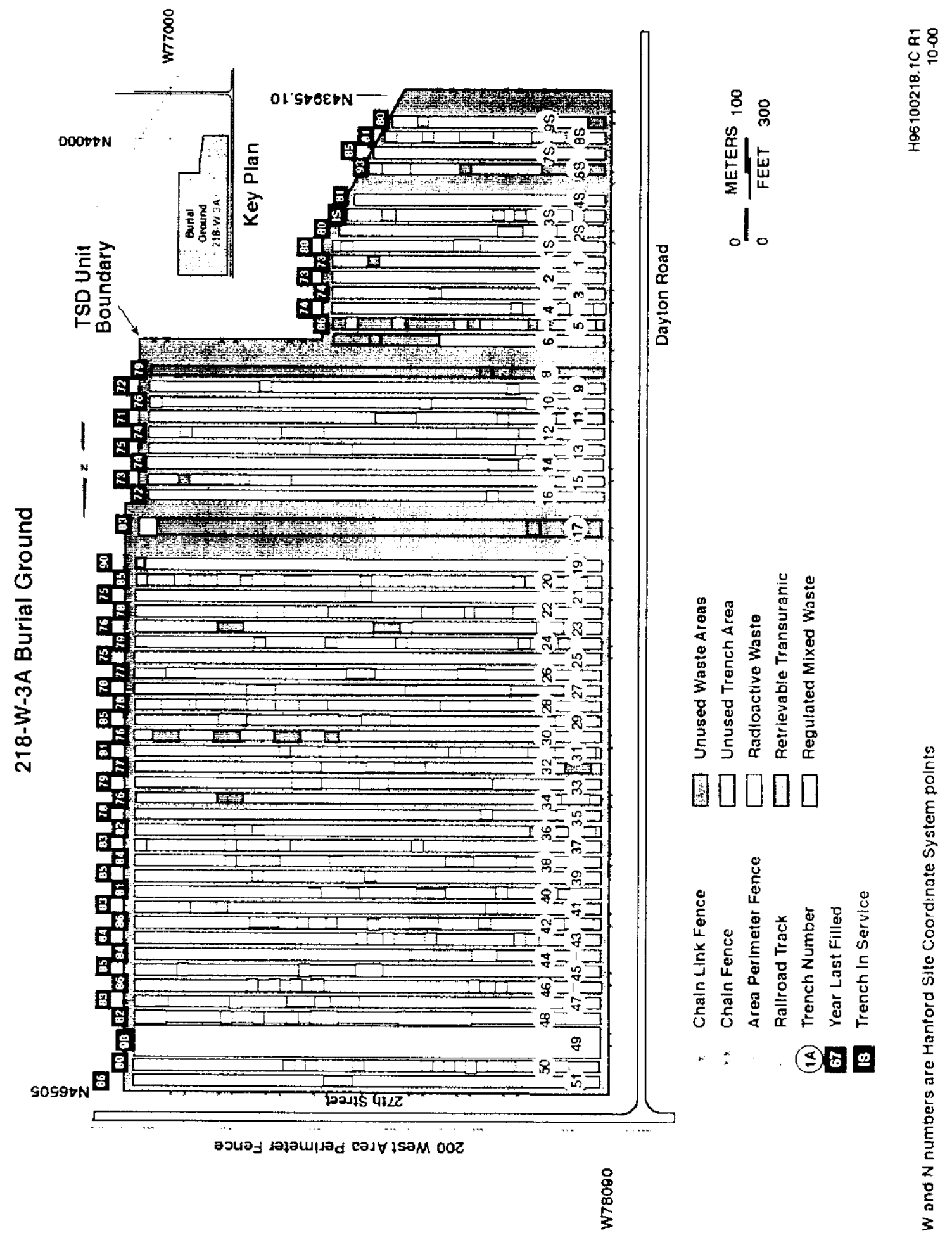

年 
DOE/RI-2000-72, Rev. ()

$11 / 2000$

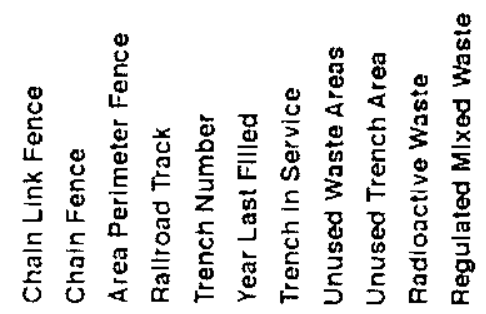

" : : : \$⿴囗十丁000
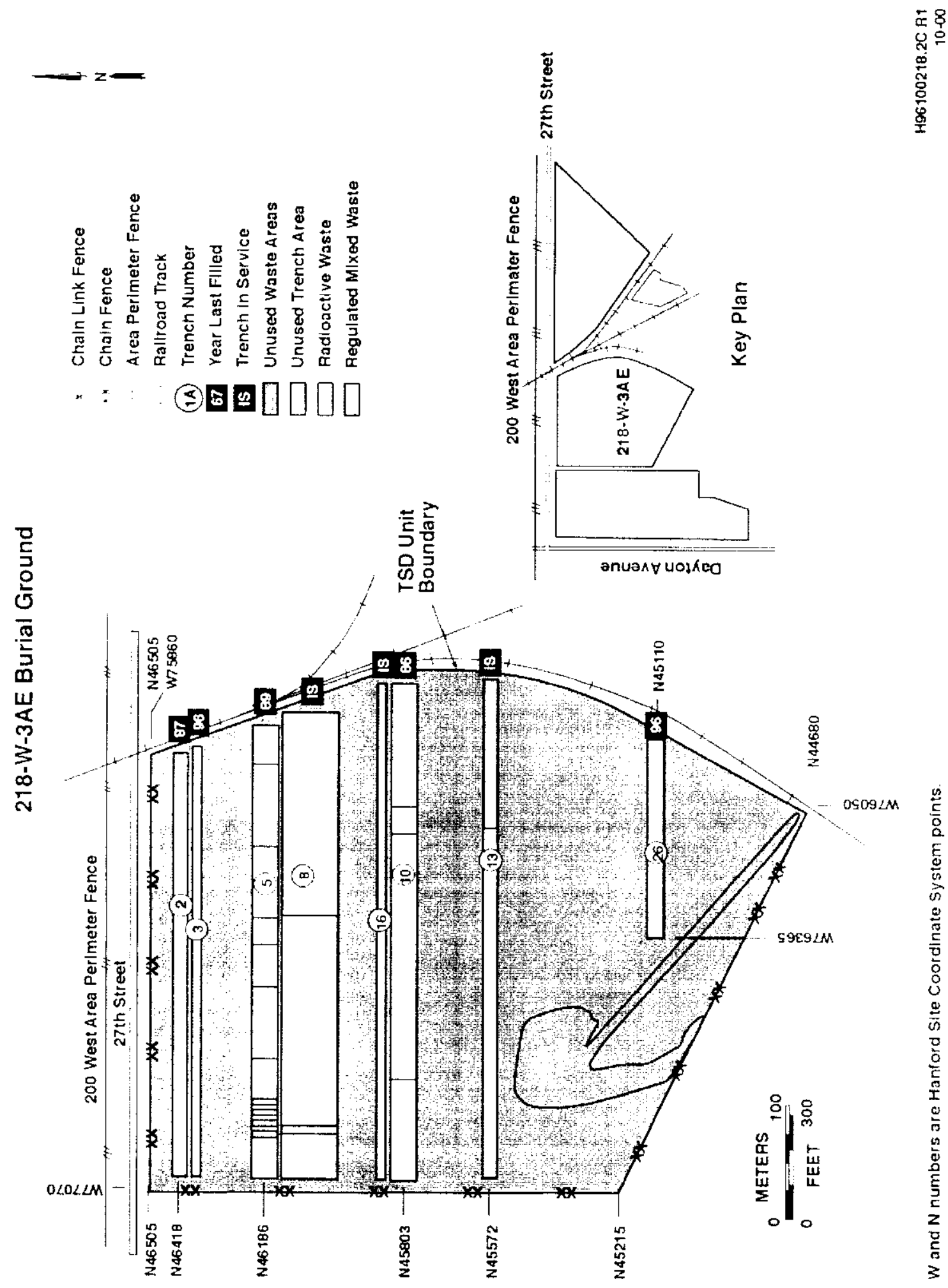
DOE/RL-2000-72, Rev. 0

$11 / 2000$

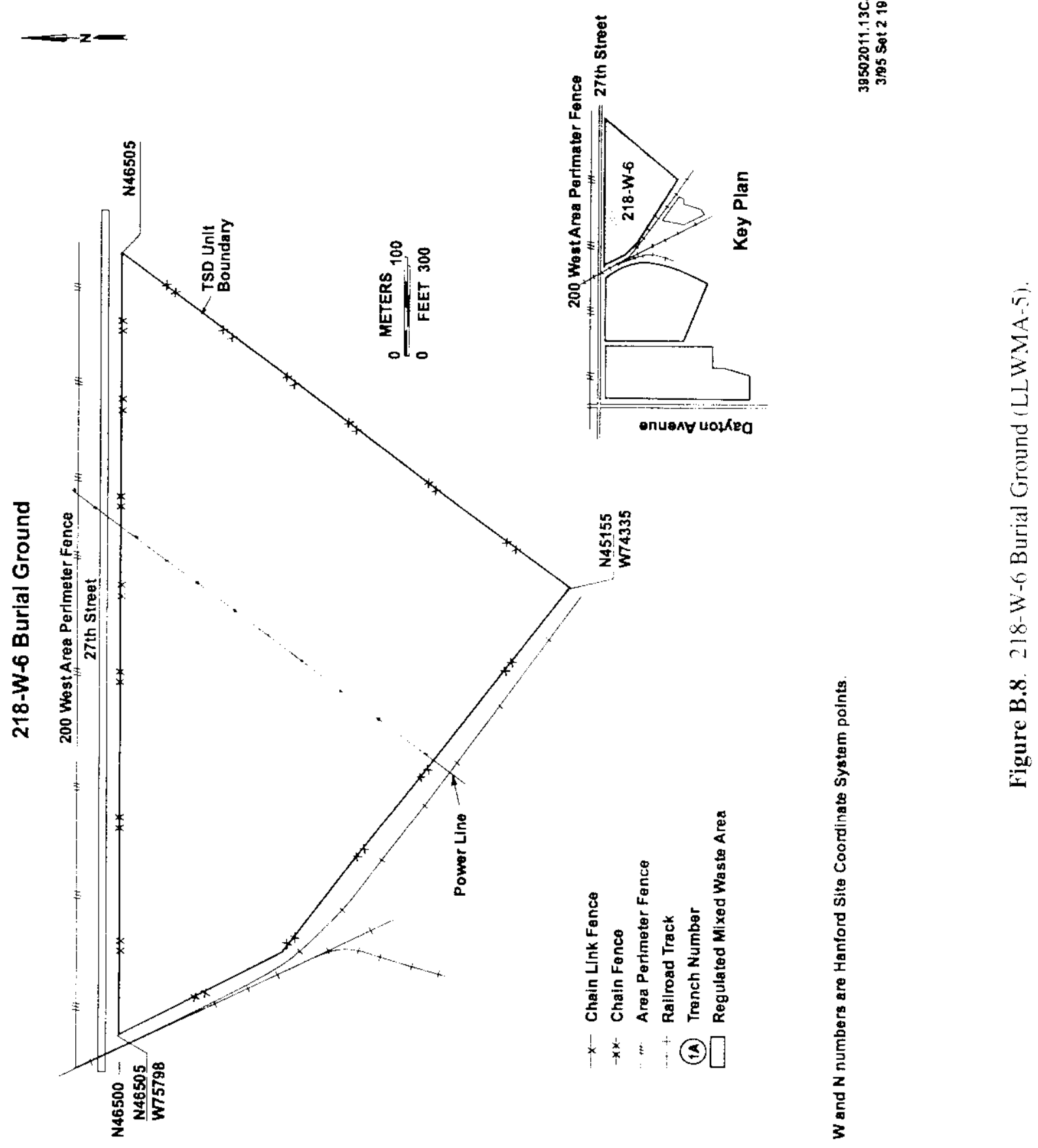


DOE/RL-2000-72, Rev. 0

\section{Appendix C}

\section{Selected Groundwater Contaminant Plume Maps in the} 200 East and 200 West Areas 
DOE/RL-2000-72, Rev. 0

$11 / 2000$

This page intentionally left blank. 
This appendix contains groundwater contaminant plume maps (Figures C. 1 through C.8) for the 200 West and 200 East Areas. The lowest concentration contours shown are for:

- $1 / 2$ the $\mathrm{MCL}^{*}$ for nitrate

- $1 / 10$ of the $1 / 25 \mathrm{DCG}^{* *}$ for technetium-99

- $1 / 20$ of the $1 / 25$ DCG for iodine- 129

- $1 / 40$ of the $1 / 25$ DCG for tritium.

The existing contamination is well below the contaminant concentrations equivalent to $4 \mathrm{mrem} / \mathrm{year}$. The contours shown were drawn based on both machine contours and knowledge of the hydrogeology of the site.

\footnotetext{
- $\mathrm{MCL}+$ maximum contaminant level
}

"* $\mathrm{DCL}=$ derived concentration guide 
DOE/RL-2000-72, Rev. 0

$11 / 2000$

This page intentionally left blank.

6 


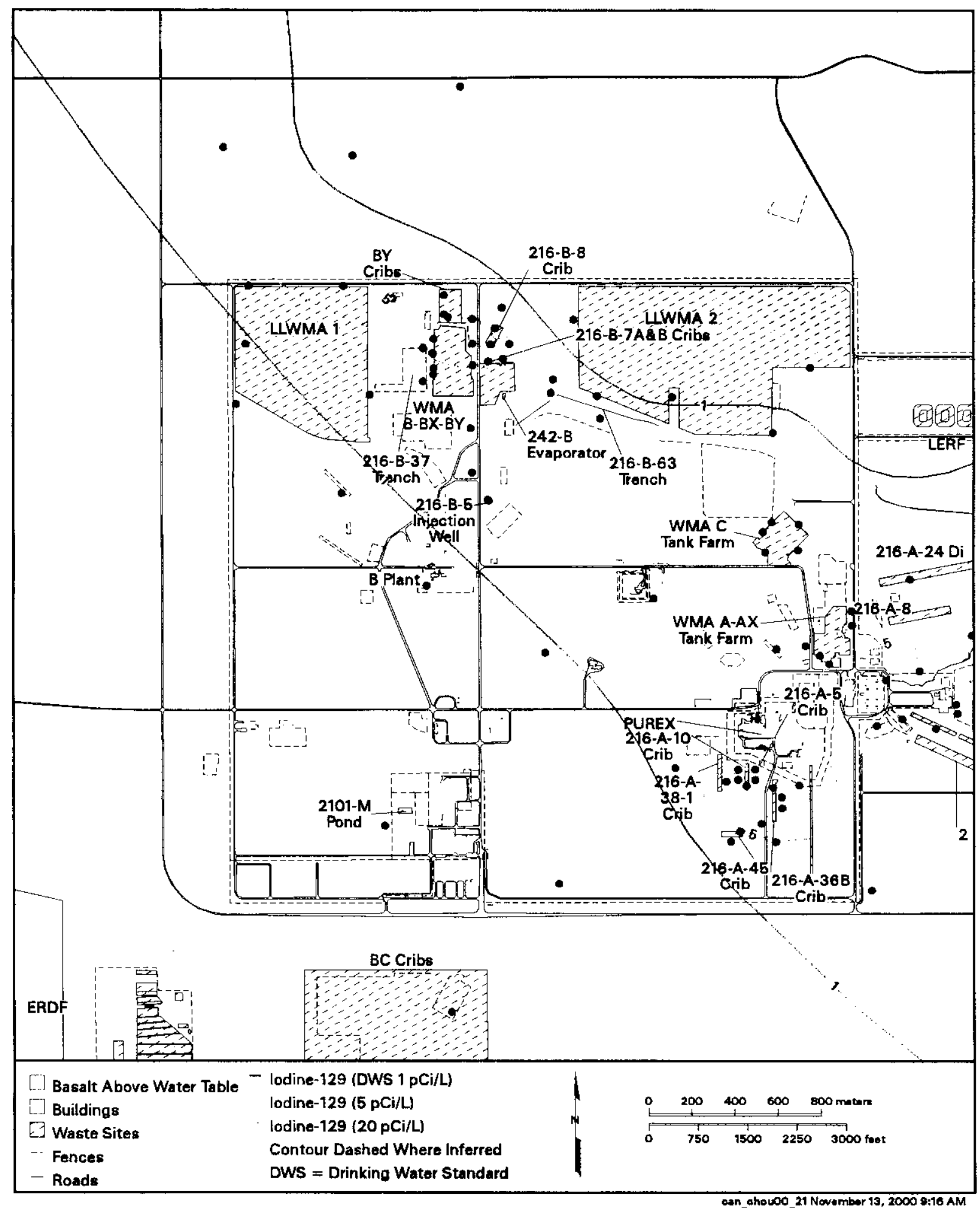

Figure C.1. Iodine-129 Plume Map, 200 East Area 


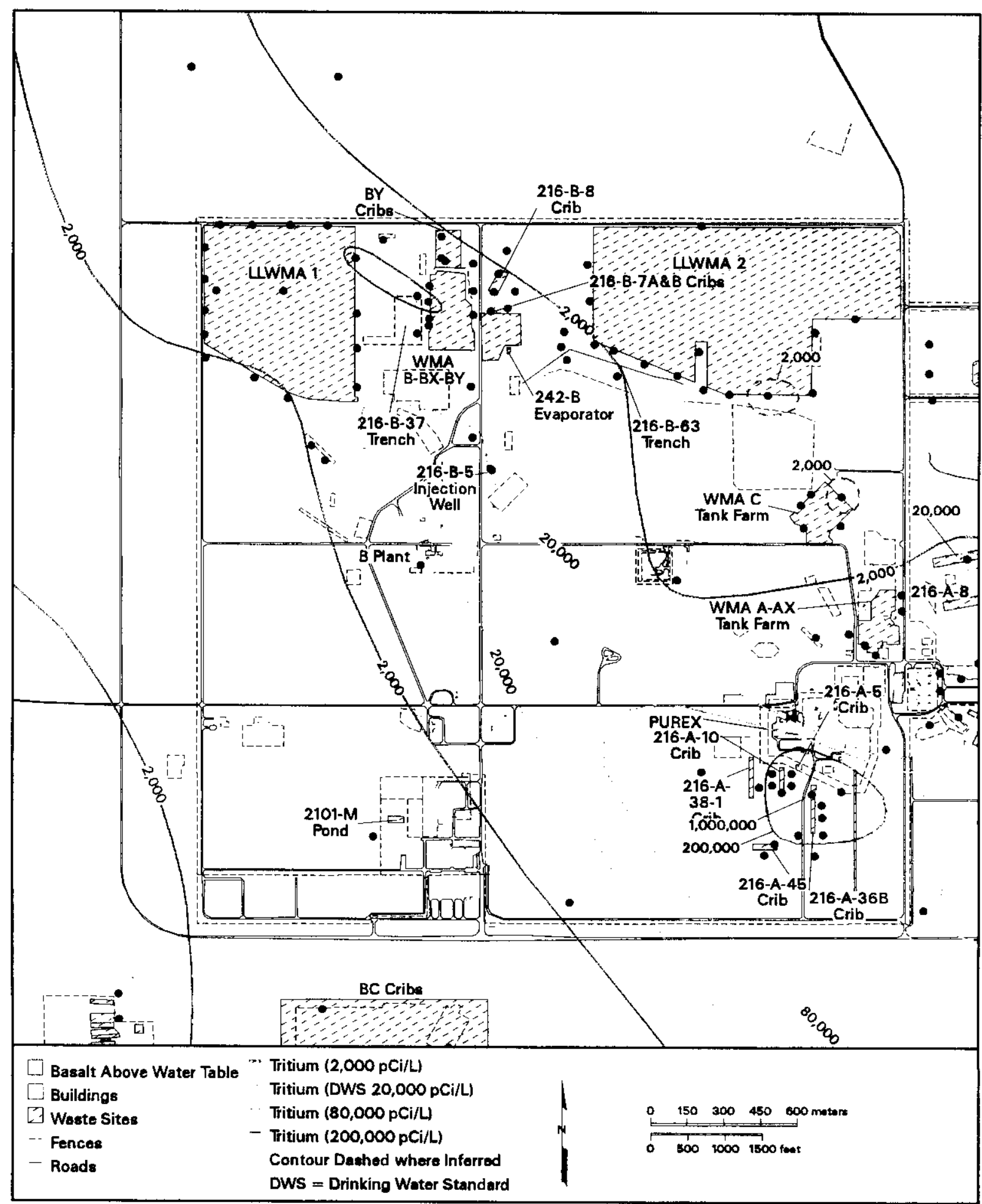

cen ehow00 10 November 13, 20000 8:15 AM

Figure C.2. Tritium Plume Map, 200 East Area 


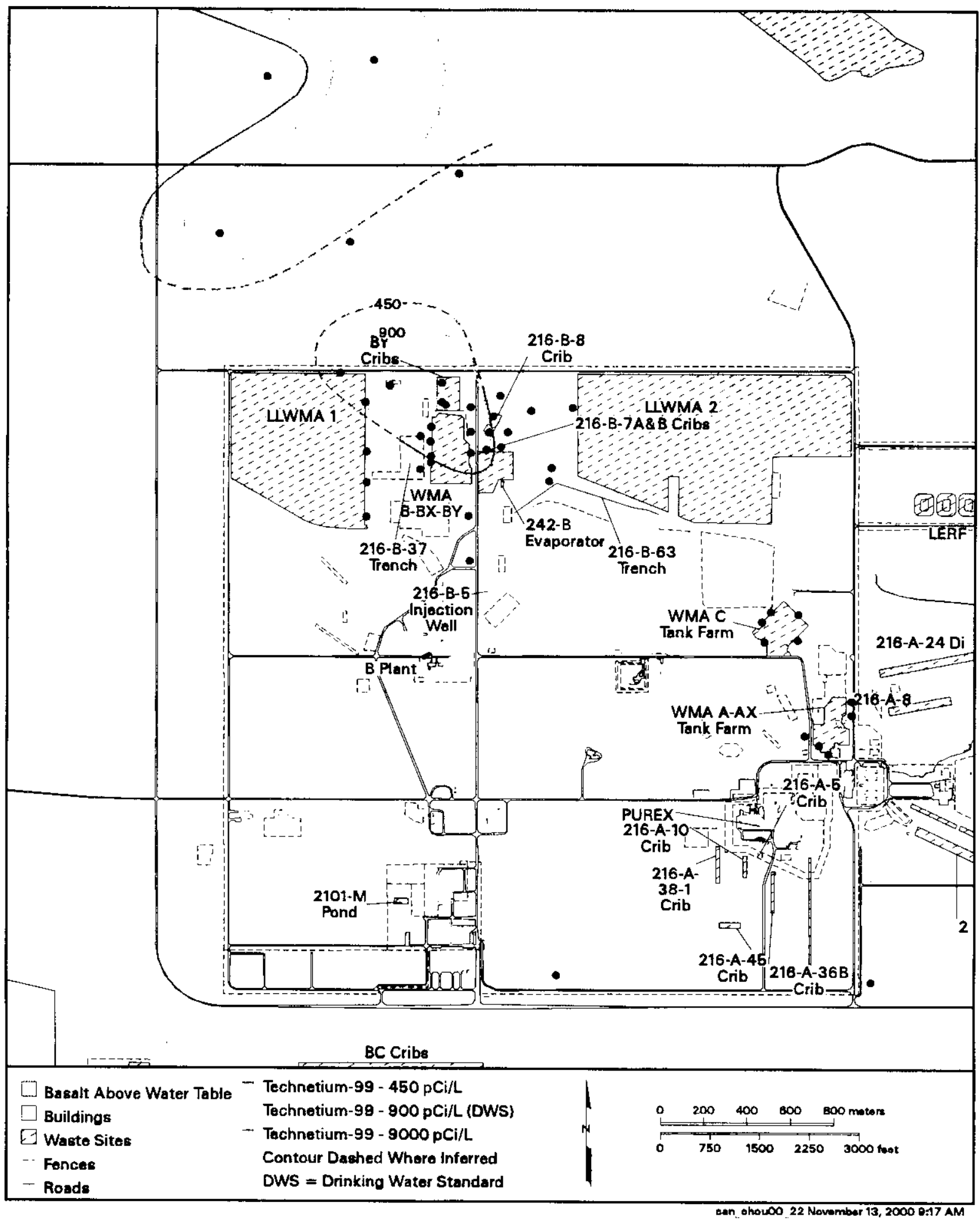

Figure C.3. Technetium-99 Plume Map, 200 East Area 


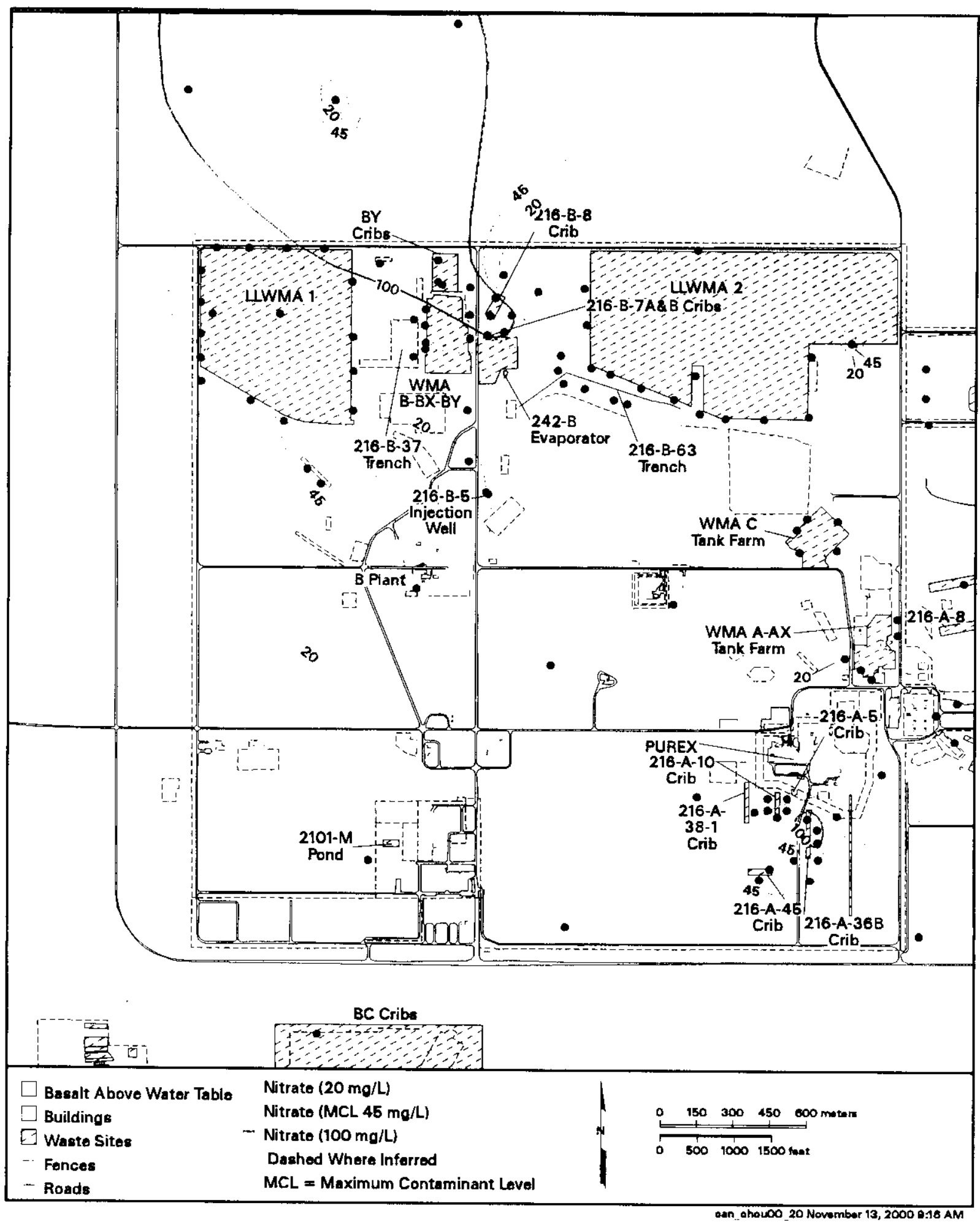

Figure C.4. Nitrate Plume Map, 200 East Area 


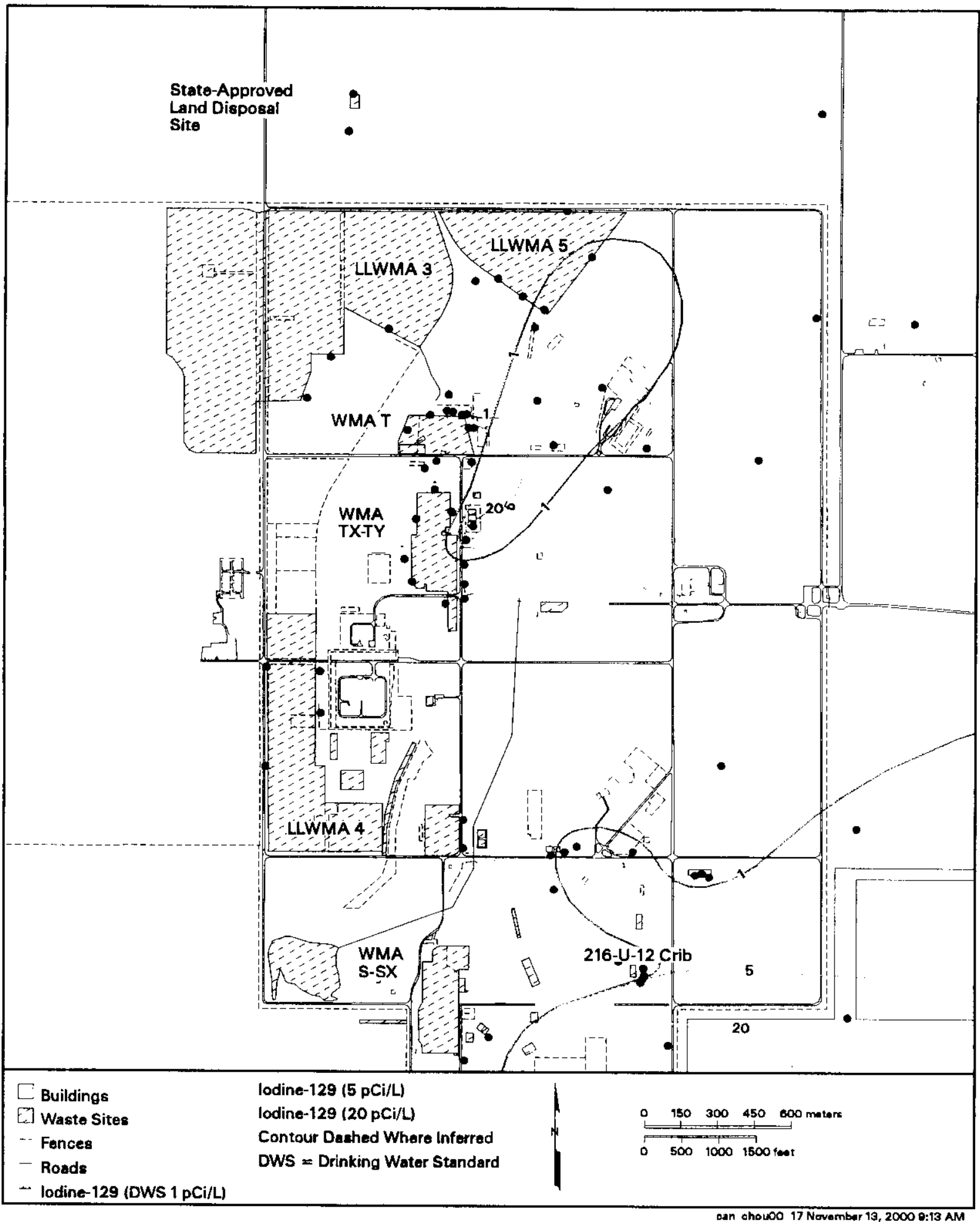

Figure C.5. Iodine-129 Plume Map, 200 West Area 


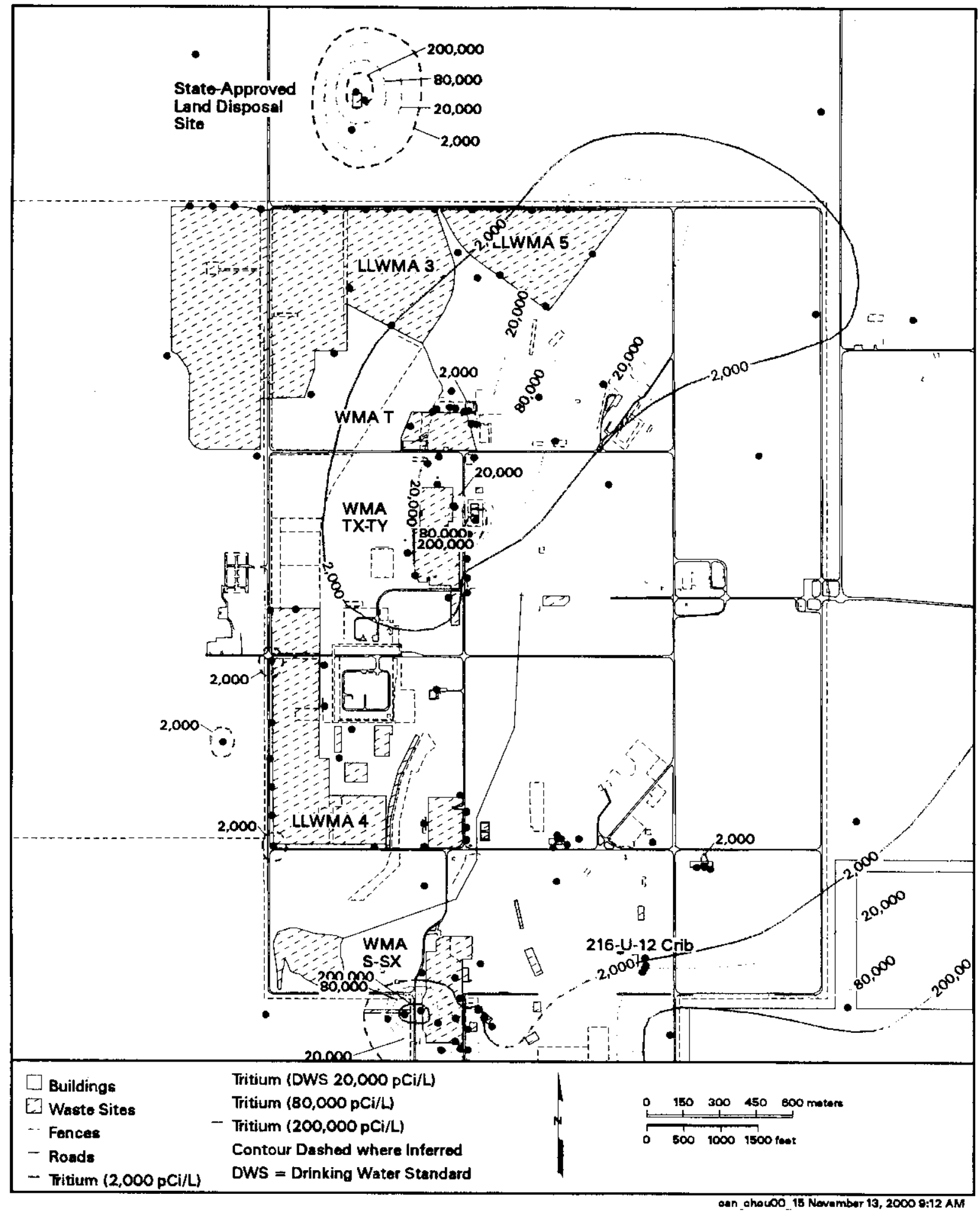

Figure C.6. Tritium Plume Map, 200 West Area 


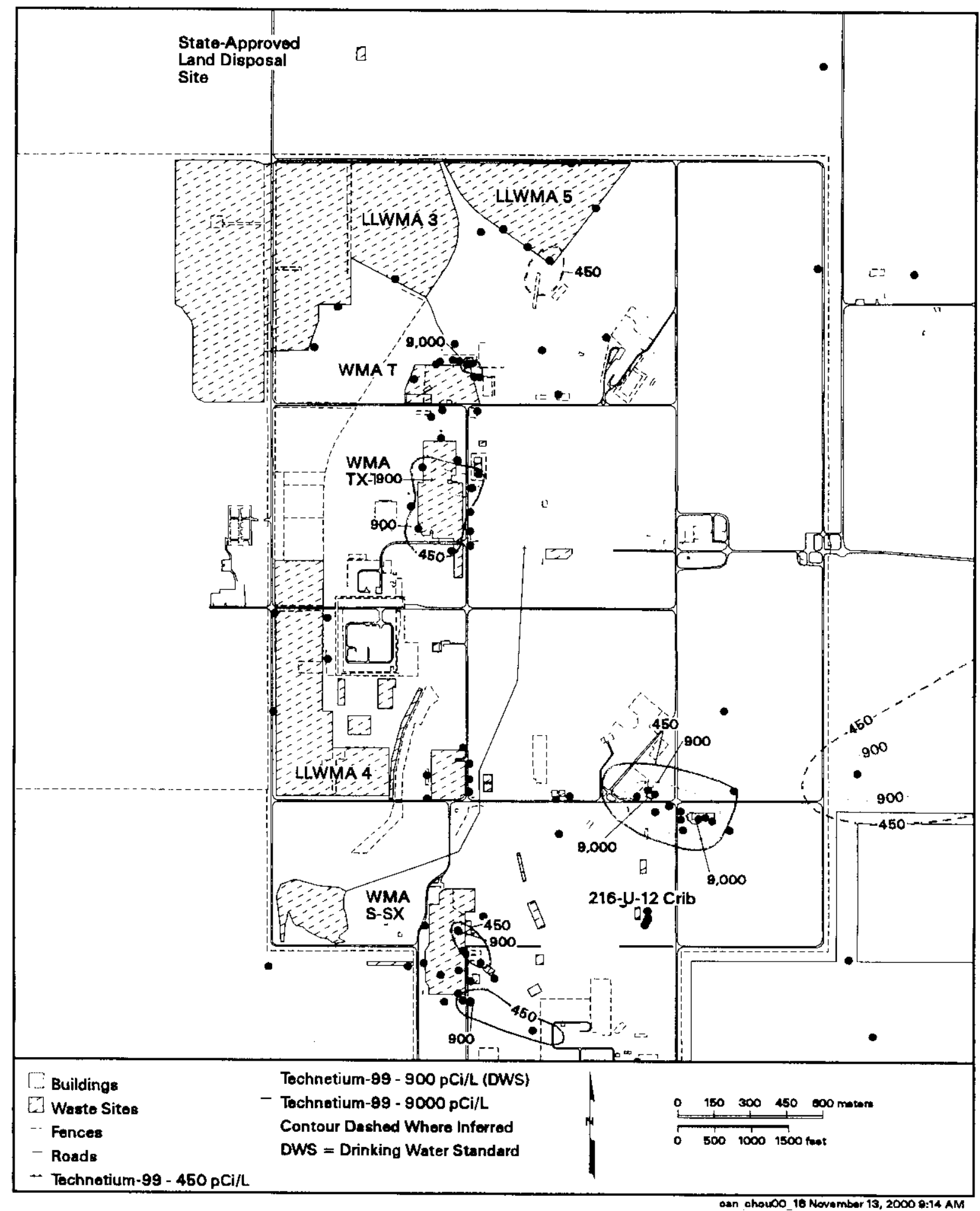

Figure C.7. Technetium-99 Plume Map, 200 West Area 


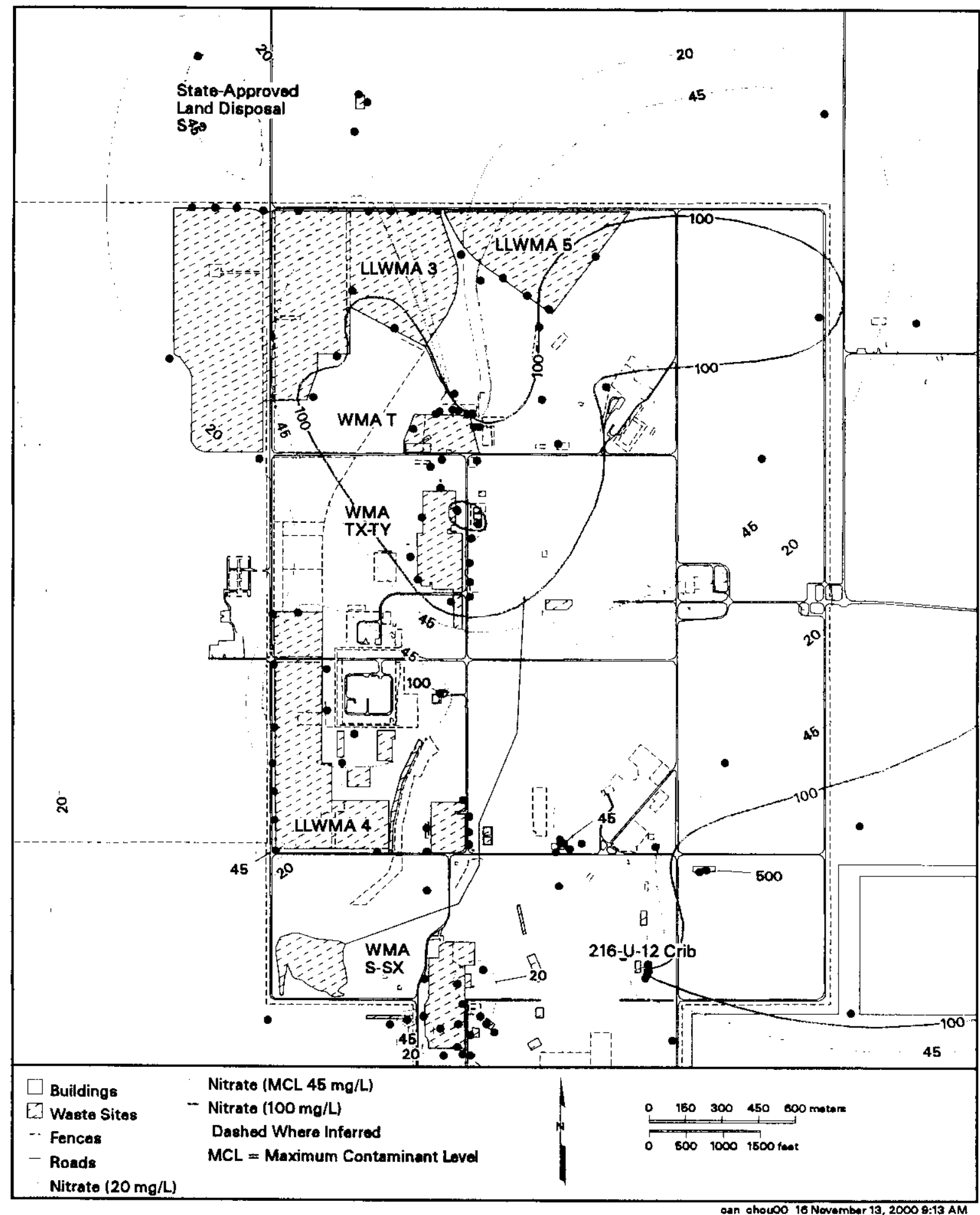

Figure C.8. Nitrate Plume Map, 200 West Area 


\section{Appendix D}

Existing Sampling and Analysis Schedules for the RCRA Groundwater Monitoring Program for the 200 Areas Low-Level Burial Grounds 
DOE/RL-2000-72, Rev. 0

$11 / 2000$

This page intentionally left blank. 


\section{Appendix D}

\section{Existing Sampling and Analysis Schedules for the RCRA Groundwater Monitoring Program for the 200 Areas Low-Level Burial Grounds}

This appendix summarizes the existing sampling and analysis schedules for the RCRA groundwater monitoring program for the Low-Level Burial Grounds. There are four separate tables (C.1 through C.4) for low-level waste management areas $1,2,3$, and 4 , respectively. Those wells that are already sampled for uranium, iodine-129 and/or technetium-99 will not be resampled for this supplemental performance assessment monitoring plan. (The groundwater project schedules all groundwater sampling and coordinates multiple requests to prevent any duplication of effort.)

\section{D.1 Reference}

WHC-SD-EN-AP-015 
Table D.1. Monitoring Wells and Constituents for Low-Level Waste Management Area $]$ (adapted from WHC-SD-EN-AP-015)

\begin{tabular}{|c|c|c|c|c|c|}
\hline Well & $\begin{array}{l}\text { Hydrogeologic Unit } \\
\text { Monitored }\end{array}$ & $\begin{array}{l}\text { Sampling } \\
\text { Frequency }\end{array}$ & $\begin{array}{l}\text { Water-Level } \\
\text { Measurement }\end{array}$ & Well Standard & Other Networks \\
\hline $299-E 28-26^{87}$ & Top of unconfined & Semiannual & Semiannual & RCRA & Surveillance \\
\hline $299-E 28-27^{87}$ & Top of unconfined & Semiannual & Semiannual & RCRA & WMA B, Surveillance \\
\hline $299-E 28-28^{90}$ & Top of unconfined & Semiannual & Semiannual & RCRA & Surveillance \\
\hline $299-\mathrm{E} 32-2^{87}$ & Top of unconfined & Semiannual & Semiannual & $\overrightarrow{\mathrm{RCRA}}$ &.- \\
\hline $299-E 32-3^{87}$ & Top of unconfined & Semiannual & Semiannual & RCRA & -- \\
\hline $299-E 32-4^{87}$ & Top of unconfined & Semiannual & Semiannual & RCRA & $216-\mathrm{B}-3$ pond \\
\hline $299-\mathrm{E} 32-5^{89}$ & Top of unconfined & Semiannual & Semiannual & RCRA & Surveillance \\
\hline $299-\mathrm{E} 32-6^{91}$ & Top of unconfined & Semiannual & Semiannual & $\mathrm{RCRA}$ & Surveillance \\
\hline $299-E 32-7^{9 !}$ & Top of unconfined & Semiannual & Semiannual & RCRA & Surveillance \\
\hline $299-E 32-8^{91}$ & Top of unconfined & Semiannual & Semiannual & RCRA & - \\
\hline $299-\mathrm{E} 32-9^{91}$ & Top of unconfined & Semiannual & Semiannual & $\overrightarrow{\mathrm{RCRA}}$ & Surveillance \\
\hline $299-\mathrm{E} 32-10^{92}$ & Top of unconfined & Semiannual & Semiannual & RCRA & Surveillance \\
\hline $299-E 33-28^{87}$ & Top of unconfined & Semiannual & Semiannual & RCRA & WMA B \\
\hline $299-E 33-29^{87}$ & Top of unconfined & Semiannual & Semiannual & $\overrightarrow{\mathrm{RCRA}}$ & WMA B \\
\hline $299-E 33-30^{87}$ & Top of unconfined & Semiannual & Semiannual & $\overrightarrow{\mathrm{RCRA}}$ & -- \\
\hline $299-\mathrm{E} 33-34^{90}$ & Top of unconfined & Semiannual & Semiannual & RCRA & WMA B \\
\hline $299-E 33-35^{90}$ & Top of unconfined & Semiannual & Semiannual & RCRA & WMA $\mathbf{B}$, Surveillance \\
\hline
\end{tabular}

\begin{tabular}{||l|l|l||}
\hline \multicolumn{2}{|c|}{ Contamination Indicator Parameters } & \multicolumn{2}{|c|}{ Site-Specific Parameters } \\
\hline \hline $\mathrm{pH}$ & Alkalinity & Lead (filtered) \\
\hline Specific conductance & Anions & Mercury (filtered) \\
\hline Total organic carbon & Gross alpha & Phenols \\
\hline Total organic halides & Gross beta & Tritium \\
\hline & ICP metals (filtered) & Turbidity \\
\hline Bold italic & Uranium & \\
Superscript $=$ Upgradient wells. & \\
ICP $=$ Year of installation. & \\
RCRA & $=$ Inductively coupled plasma emission spectroscopy. \\
WMA & $=$ Well constructed to RCRA standards. \\
\hline
\end{tabular}


Table D.2. Monitoring Wells and Constituents for Low-Level Waste Management Area 2 (adapted from WHC-SD-EN-AP-015)

\begin{tabular}{|c|c|c|c|c|c|}
\hline Well & $\begin{array}{l}\text { Hydrogeologic Unit } \\
\text { Monitored }\end{array}$ & $\begin{array}{l}\text { Sampling } \\
\text { Frequency }\end{array}$ & $\begin{array}{l}\text { Water-Level } \\
\text { Measurement }\end{array}$ & Well Standard & Other Networks \\
\hline 299-E27-8 ${ }^{87}$ & Top of unconfined & Semiannual & Semiannual & RCRA & 216-B-63 trench \\
\hline $299-E 27-9^{87}$ & Top of unconfined & Semiannual & Semiannual & RCRA & 216-B-63 trench \\
\hline $299-E 27-10^{9 t}$ & Top of unconfined & Semiannual & Semiannual & RCRA & -. \\
\hline $299-E 27-11^{89}$ & Top of unconfined & Semiannual & Semiannual & RCRA & 216-B-63 trench \\
\hline $299-\mathrm{E} 27-17^{91}$ & Top of unconfined & Semiannual & Semiannual & RCRA & $\begin{array}{l}\text { 216-B-63 trench, } \\
\text { Surveillance }\end{array}$ \\
\hline $299-\mathrm{E} 34-2^{8^{77}}$ & Top of unconfined & Semiannual & Semiannual & RCRA & Surveillance \\
\hline $299-E 34-3^{87}$ & Top of unconfined & Semiannual & Semiannual & RCRA & -- \\
\hline $299-E 34-4^{87}$ & Top of unconfined & Dry & Dry & RCRA & $m$ \\
\hline $299-E 34-5^{87}$ & Top of unconfined & Semiannual & Semiannual & RCRA & Surveillance \\
\hline $299-E 34-6^{87}$ & Top of unconfined & Dry & Dry & RCRA & -- \\
\hline $299-E 34-7^{89}$ & Top of unconfined & Semiannual & Semiannual & RCRA & Surveillance \\
\hline $299-\mathrm{E} 34-9^{91}$ & Top of unconfined & Semiannual & Semiannual & RCRA & Surveillance \\
\hline $299-\mathrm{E} 34-10^{91}$ & Top of unconfined & Semiannual & Semiannual & RCRA & $\begin{array}{l}216-B-63 \text { Trench, } \\
\text { Surveillance }\end{array}$ \\
\hline $299-E 34-11^{92}$ & Top of unconfined & Semiannual & Semiannual & RCRA & -- \\
\hline $299-\mathrm{E} 34-12^{92}$ & Top of unconfined & Semiannual & Semiannual & RCRA & - \\
\hline $299-E 35-I^{89}$ & Top of unconfined & Dry & Dry & RCRA & -- \\
\hline
\end{tabular}

\begin{tabular}{||l|l|l||}
\hline \multicolumn{1}{|c|}{ Contamination Indicator Parameters } & \multicolumn{2}{|c||}{ Site-Specific Parameters } \\
\hline \hline $\mathrm{pH}$ & Alkalinity & Mercury (filtered) \\
\hline Specific conductance & Anions & Phenols \\
\hline Total organic carbon & Gross alpha & Polychlorinated biphenyls \\
\hline Total organic halides & Gross beta & Tritium \\
\hline & ICP metals (filtered) & Turbidity \\
\hline \multicolumn{2}{|l|}{$=$ Lead (filtered) } & \\
\hline $\begin{array}{l}\text { Bold italic }=\text { Upgradient wells. } \\
\text { ICP }=\text { Year of installation. }\end{array}$ \\
RCRA $=$ Inductively coupled plasma emission spectroscopy. \\
\hline
\end{tabular}


Table D.3. Monitoring Wells and Constituents for Low-Level Waste Management Area 3 (adapted from WHC-SD-EN-AP-015)

\begin{tabular}{|c|c|c|c|c|c|}
\hline Well & $\begin{array}{l}\text { Hydrogeologic Unit } \\
\text { Monitored }\end{array}$ & $\begin{array}{l}\text { Sampling } \\
\text { Frequency }\end{array}$ & $\begin{array}{l}\text { Water-Level } \\
\text { Measurement }\end{array}$ & Well Standard & Other Networks \\
\hline $299-W 6-2^{87}$ & Top of unconfined & Semiannual & Semiannual & RCRA & WMA T, Surveillance \\
\hline $299-W 7-1^{87}$ & Top of unconfined & Semiannual & Semiannual & RCRA & SALDS \\
\hline $299-W 7-2^{87}$ & Top of unconfined & Dry & Dry & RCRA & - \\
\hline $299-W 7-3^{87}$ & Deep unconfined & Semiannual & Semiannual & RCRA & SALDS \\
\hline $299-W^{7}-4^{87}$ & Top of unconfined & Semiannual & Semiannual & RCRA & -- \\
\hline $299-W 7-5^{87}$ & Top of unconfined & Semiannual & Semiannual & RCRA & SALDS, Surveillance \\
\hline $299-W 7-6^{87}$ & Top of unconfined & Semiannual & Semiannual & RCRA & SALDS, Surveillance \\
\hline $299-W 7-7^{89}$ & Top of unconfined & Semiannual & Semiannual & RCRA & SALDS \\
\hline $299-W 7-8^{89}$ & Top of unconfined & Semiannual & Semiannual & RCRA & SALDS, Surveillance \\
\hline $299-W 7-9^{90}$ & Top of unconfined & Semiannual & Semiannual & RCRA & SALDS \\
\hline $299-W 7.10^{90}$ & Top of unconfined & Semiannual & Semiannual & RCRA & - \\
\hline $299-W 7-11^{91}$ & Top of unconfined & Semiannual & Semiannual & RCRA & SALDS, Surveillance \\
\hline $299-W 7-12^{91}$ & Top of unconfined & Semiannual & Semiannual & RCRA & SALDS, Surveillance \\
\hline $299-W 8.1^{87}$ & Top of unconfined & Semiannual & Semiannual & RCRA & SALDS, Surveillance \\
\hline $299-W 9-I^{87}$ & Top of unconfined & Dry & Dry & RCRA & Surveillance \\
\hline $299-W 10-13^{87}$ & Top of unconfined & Semiannual & Semiannual & RCRA & Surveillance \\
\hline $299-W 10-14^{87}$ & Deep unconfined & Semiannual & Semiannual & RCRA & -- \\
\hline $299-W 10-19^{92}$ & Top of unconfined & Semiannual & Semiannual & RCRA & WMA T \\
\hline $299-W 10-20^{93}$ & Top of unconfined & Semiannual & Semiannual & RCRA & WMA T, Surveillance \\
\hline $299-W 10-21^{93}$ & Top of unconfined & Semiannual & Semiannual & $\overline{\mathrm{RCRA}}$ & WMA T, Surveillance \\
\hline
\end{tabular}

\begin{tabular}{|c|c|c|c|}
\hline \multicolumn{2}{|c|}{ Contamination Indicator Parameters } & \multicolumn{2}{|c|}{ Site-Specific Parameters } \\
\hline \multicolumn{2}{|l|}{$\mathrm{pH}$} & Alkalinity & Mercury (filtered) \\
\hline \multicolumn{2}{|c|}{ Specific conductance } & Anions & Phenols \\
\hline \multicolumn{2}{|c|}{ Total organic carbon } & Gross alpha & Tritium \\
\hline \multicolumn{2}{|c|}{ Total organic halides } & Gross beta & Turbidity \\
\hline & & ICP metals (filtered) & Volatile organic compounds \\
\hline & & Lead (filtered) & \\
\hline $\begin{array}{l}\text { Bold italic } \\
\text { Superscript } \\
\text { RCRA } \\
\text { SALDS } \\
\text { WMA }\end{array}$ & $\begin{array}{l}=\mathrm{Up} \\
=\mathrm{Ye} \\
=\mathrm{We} \\
=\mathrm{Sta} \\
=\mathrm{Wa}\end{array}$ & $\begin{array}{l}\text { ds. } \\
\text { e. }\end{array}$ & \\
\hline
\end{tabular}


Table D.4. Monitoring Wells and Constituents for Low-Level Waste Management Area 4 (adapted from WHC-SD-EN-AP-015)

\begin{tabular}{|c|c|c|c|c|c|}
\hline Well & $\begin{array}{c}\text { Hydrogeologic Unit } \\
\text { Monitored }\end{array}$ & $\begin{array}{l}\text { Sampling } \\
\text { Frequency }\end{array}$ & $\begin{array}{l}\text { Water-Level } \\
\text { Measurement }\end{array}$ & Well Standard & Other Networks \\
\hline $299-\mathrm{W15}-15^{\text {of, a) }}$ & Top of unconfined & Semiannual & Semiannual & RCRA & $200-\mathrm{ZP}-1$ \\
\hline $299-W 15-16^{8 / .(8)}$ & Top of unconfined & Semiannual & Semiannual & RCRA & -- \\
\hline $299-\mathrm{W} 15-17^{81}$ & Deep unconfined & Semiannual & Semiannual & RCRA & -- \\
\hline $299-\mathrm{W} 15-18^{87,(\mathrm{a})}$ & Top of unconfined & Semiannual & Semiannual & $\overline{\mathrm{RCRA}}$ & -- \\
\hline $299-W 15-19^{89}$ & Top of unconfined & Dry & Dry & RCRA & $\begin{array}{l}\text { 200-ZP-1, } \\
\text { Surveillance }\end{array}$ \\
\hline $299-W 15-20^{39}$ & Top of unconfined & $\overline{\text { Dry }}$ & Dry & RCRA & - \\
\hline $299-W 15-23^{90,(a)}$ & Top of unconfined & $\overline{\text { Dry }}$ & Dry & $\overline{R C R A}$ & -- \\
\hline $299-W 15-24^{39}$ & Top of unconfined & Dry & Dry & RCRA & $\ldots$ \\
\hline $299-W 18-2 I^{\prime \prime}$ & Top of unconfined & Semiannual & Semiannual & RCRA & $200-\mathrm{ZP}-1$ \\
\hline $299-W 18-22^{87}$ & Deep unconfined & Semiannual & Semiannual & RCRA & Surveillance \\
\hline $299-W 18-23^{87}$ & Top of unconfined & Semiannual & Semiannual & RCRA & $200-Z \mathrm{P}-1$ \\
\hline $299-W 18-24^{87}$ & Top of unconfined & Semiannual & Semiannual & RCRA & -- \\
\hline $299-W 18-26^{89}$ & Top of unconfined & Dry & Dry & & -- \\
\hline $299-W 18-27^{71}$ & Top of unconfined & Semiannual & Semiannual & RCRA & $200-\mathrm{ZP}-1$ \\
\hline $299-W 18-28^{91}$ & Top of unconfined & Semiannual & Semiannual & RCRA & -- \\
\hline $299-W 18-29^{91}$ & Perched zone & Dry & Dry & RCRA & -- \\
\hline $299-W 18-32^{97}$ & Top of unconfined & Dry & Dry & $\overline{\mathrm{RCRA}}$ & $200-Z P-1$ \\
\hline
\end{tabular}

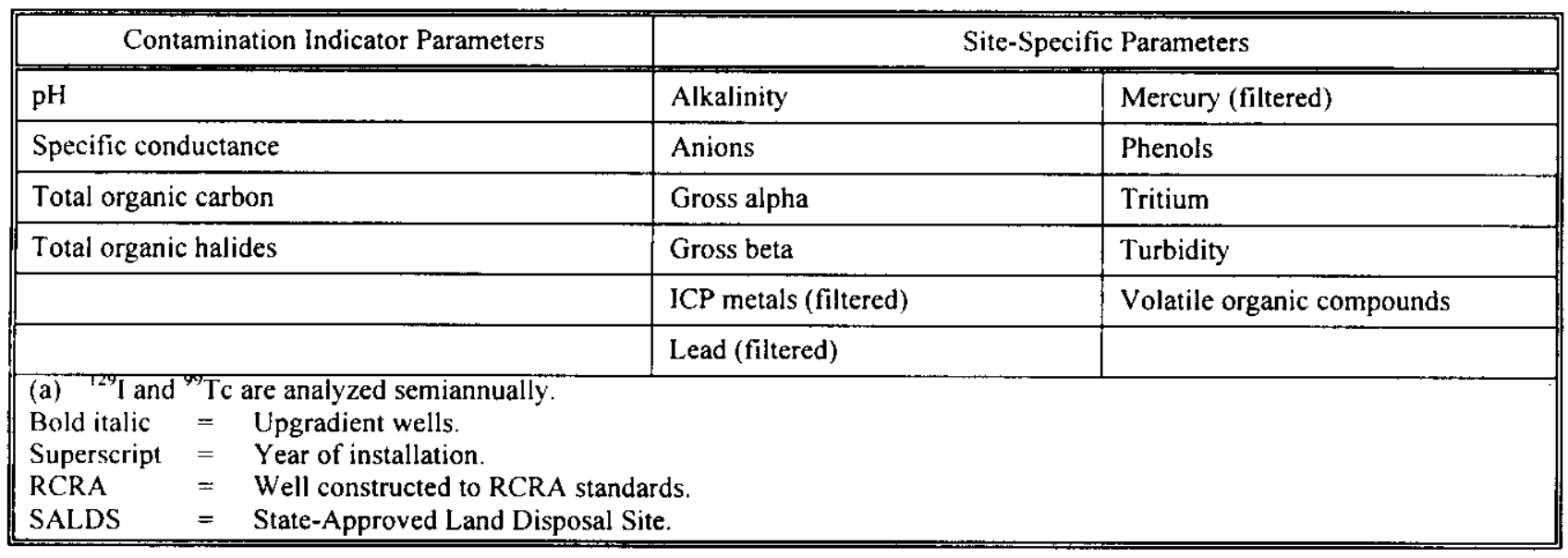


DOE/RL-2000-72, Rev. 0

$11 / 2000$

This page intentionally left blank. 


\section{DISTRIBUTION}

MSIN

U.S. Department of Energy, Richland Operations Office

B. E. Bilson

H0-12

R. F. Guercia

$\mathrm{H} 0-12$

G. H. Sanders

$\mathrm{H} 0-12$

T. A. Shrader

G. L. Sinton

H0- 12

$\mathrm{H} 0-12$

Fluor Hanford

E. S. Aromi

H6-10

R. H. Engelmann

G1-30

C. K. Girres

T3-01

R. D. Greenwell

T4-04

D. A. Pratt

T4-03

D. G. Saueressig

T4-04

J. C. Sonnichsen

G1-30

M. I. Wood

H8-44

Pacific Northwest National Laboratory

J. Bush

K6-96

C. J. Chou

K6-81

J. S. Fruchter

K6-96

V. G. Johnson

K6-96

S. P. Luttrell

K6-96

W. J. Martin

K6-81

R. B. Mercer

K6-96

S. Reidel

K6-81

M. D. Sweeney

K6-81

Hanford Technical Library

$\mathrm{K} !-11$

Lockheed Martin Services, Inc.

Central Files

B 1-07

EDMC (2)

H6-08

DPC

H6-08 
DOE/RL-2000-72, Rev. 0

$11 / 2000$

This page intentionally left blank. 